UNIVERSIDADE DE SÃO PAULO

FACULDADE DE FILOSOFIA, LETRAS E CIÊNCIAS HUMANAS DEPARTAMENTO DE LETRAS ORIENTAIS

PROGRAMA DE PÓS-GRADUAÇÃO EM ESTUDOS JUDAICOS E ÁRABES

ANA CAROLINA PINHEIRO E CASTRO

OS ENGASTES DAS SABEDORIAS

- A METAFÍSICA DO REAL EM IBN 'ARABĪ - 
UNIVERSIDADE DE SÃO PAULO

FACULDADE DE FILOSOFIA, LETRAS E CIÊNCIAS HUMANAS

DEPARTAMENTO DE LETRAS ORIENTAIS

PROGRAMA DE PÓS-GRADUAÇÃO EM ESTUDOS JUDAICOS E ÁRABES, ÁREA DE CONCENTRAÇÃO EM ESTUDOS ÁRABES

OS ENGASTES DAS SABEDORIAS

- A METAFÍSICA DO REAL EM IBN 'ARABĪ -

ANA CAROLINA PINHEIRO E CASTRO

Dissertação apresentada como requisito parcial para a obtenção do título de Mestre em Letras (Estudos Judaicos e Árabes), na Área de Concentração em Estudos Árabes, ao Departamento de Letras Orientais da Faculdade de Filosofia, Letras e Ciências Humanas da Universidade de São Paulo, sob a orientação do Prof. Dr. Miguel Attie Filho.

SÃO PAULO 


\section{DE ACORDO}

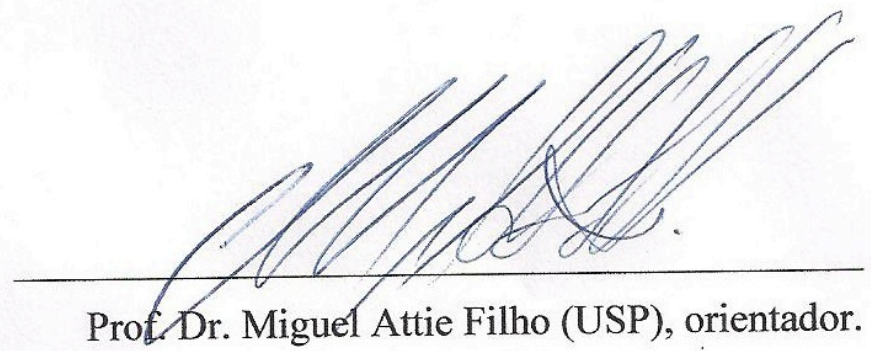

Prof ${ }^{a} \mathrm{Dr}^{\mathrm{a}}$ Safa Alferd Abou Chahla Jubran (USP), examinadora.

Prof. Dr. Antonio José Romera Valverde, examinador. 


\section{RESUMO}

A obra de Ibn 'Arabī (1165 d.C. $/ 560$ H.) é bastante extensa, compreendendo cerca de 400 títulos, dos quais Kitāb fușūṣ al-hikam (O livro dos engastes das sabedorias) destaca-se como um dos principais escritos no qual o autor apresenta sua concepção metafísica, de forma mais sistematizada, como sua teoria dos nomes divinos através dos quais a essência do real procede, manifestando todos os existentes, assim como trata, de maneira aprofundada, do significado dos profetas e das sabedorias por eles transmitidas, propondo uma conotação totalmente metafísica para o profético. A profecia assume, nessa obra, uma importância fundamental, ela é apresentada como a condição de possibilidade da existência determinada, assim como também a condição de possibilidade do conhecimento da essência do real, ou seja, a condição de possibilidade de conhecer a realidade primeira. É interessante notar ainda a riqueza e a complexidade discursiva, na qual vida e obra encontram-se implicadas nesse processo de existenciação, de modo que tanto o autor quanto sua obra recebem estatutos muito significativos e particulares referentes ao sistema metafísico apresentado.

Servindo-se da filosofia, da teologia e da mística arabo-islâmicas, oferecendo, com isso, um pensamento, embora complexo, de alcance universal que reconhece todos os profetas do ciclo histórico e as diversas tradições reveladas, a hermenêutica de Ibn 'Arabī evidencia-se em muito original, promovendo um diálogo criativo e conciliador entre diversas culturas, permanecendo, até os dias de hoje, profundamente rico, inovador e inspirador para as mais diversas culturas e domínios do pensamento.

Palavras-chave: Filosofia, Metafísica, Real, Existência, Existência Determinada, Essência, Ciência, Epistemologia, Profetas, Profecia, Sabedorias, Revelação, Ibn 'Arabī, Mística, Sufismo. 


\begin{abstract}
The work of Ibn 'Arabī (1165 AD / H. 560) is quite extensive, comprising about 400 titles, of which Kitāb fușūs al-hikam (The Book of the bezels of wisdom) stands out as one of the major writings in which the author presents his metaphysical conception in a more systematic way as his theory of divine names, by which the essence of real conceives, showing all as he deeply addresses, the meaning of the prophets and the wisdom transmitted by them, proposing an entirely metaphysical connotation for the prophetic. On this work, the prophecy itself assumes a fundamental importance. It is presented as the condition of possibility of determined existence, as well as the condition of possibility of knowledge of the essence of real, i.e.: the condition of possibility of knowing the first reality. It is quite interesting to notice the richness and discursive complexity, in which life and the paper are implied in this existence process, so that both the author and his work receive very significant and specific status relating to the metaphysical system presented.

Making use of philosophy, theology and the Arab-Islamic mysticism, offering thereby a thought, though complex, universal reach that recognizes all the prophets of the historical cycle and several revealed traditions, the hermeneutic of Ibn 'Arabī evidences itself as being very original, promoting a creative and conciliatory dialogue among several cultures and remaining until this day, deeply rich, innovative and inspiring for several cultures and thought domains.
\end{abstract}

Keywords: Philosophy, Metaphysics, Real, Existence, Determined Existence, Essence, Science, Epistemology, Prophets, Prophecy, Wisdom, Revelation, Ibn 'Arabī, Mysticism, Sufism. 


\section{AGRADECIMENTOS}

Agradeço de todo o coração à Gurumayi Chidvilasananda a quem devo minha existência, junto a quem meu coração encontra-se unido.

Agradeço de todo o coração aos meus irmãos Silvia Maria e Marco Antonio porque só sei ser com eles.

Agradeço de todo o coração a minha mãe Inês, com devoção, pelas bençãos infinitas, pelo olhar sempre amoroso, pela eterna e contínua companhia, pela sua força e genorosidade.

Agradeço de todo o coração ao meu pai José Henrique por quem sempre devotei minha total admiração e amor. Obrigada meu pai.

Agradeço à querida Cristiane Negreiros Abbud Ayoub, pela sua graça e luz, sempre. Agradeço à querida Lara Cristina Malimpensa por ter iluminado meus caminhos com a sua paz.

Agradeço ao querido Ronaldo Miranda, seus raios de amizade e carinho, sua arte e sua presença contínua nutrem, inspiram e apoiam a minha vida. Obrigada pela sua alegria, Ronaldo.

Agradeço pela amizade luminosa, pela generosidade, pelo olhar sempre raro e inspirado, por todos os gestos de carinho de Rafael Ramalho, Jaykara, a quem devo o primeiro contato com os escritos de James Hillman e que me possibilitaram chegar até aqui.

Agradeço especialmente a minha amiga adorada Karim do Nascimento.

Agradeço especialmente à Marcia, à Ciça e à Alcione pelas incontáveis bençãos, por tanta generosidade, amizade e apoio.

Agradeço ao meu amigo querido Ari, pelo entusiasmo e alegria que sempre experimento em sua presença.

Agradeço especialmente à Nathalia, ao Mateus e ao Daniel, por estarmos juntos nesse aprendizado e pela amizade sincera.

Agradeço especialmente e com toda a admiração ao Prof. Dr. Antonio José Romera Valverde pelo seu acolhimento, carinho e generosidade, sempre.

Agradeço especialmente ao Prof. Dr. Pablo Ortellado pela contínua presença e amizade.

Agradeço especialmente à Prof. ${ }^{\text {a }}$ Dr. ${ }^{a}$ Safa Jubran e ao Prof. Dr. Mamede Jarouche pelo acolhimento, entusiasmo, generosidade, conhecimento e assistência de sempre.

A gratidão, a admiração, o respeito, o carinho que nutro e ofereço ao meu orientador Prof. Dr. Miguel Attie Filho não cabem nessas palavras, não caberão em nenhuma e estarão sempre voltados em sua direção. 
À Gurumayi Chidvilasananda 
Existe um sopro

de divino espírito

que se compraza

em dilatar-se tanto

quanto for o espaço capaz de contê-lo.

\author{
Esse mesmo sopro \\ é atraído para o interior \\ das coisas e dos corpos \\ de todos os seres que, \\ como um ventre, \\ é esculpido, \\ detalhadamente talhado, \\ pelo vazio
}

que é toda a entrega que se pode ser.

Então, como é o vazio

esculpido da flauta,

o sopro é irresistivelmente atraído

para dentro dela.

E, pela mesma irresistivel vontade,

sopra o músico

o divino sopro que o habita.

Imenso,

íntimo sopro de dentro de tudo. 
Tabela de transliteração..................................................................................... 1

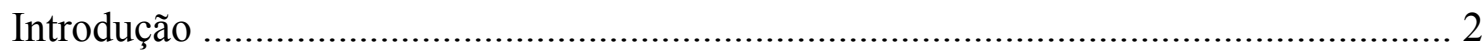

\section{CAPÍTULO I \\ IBN 'ARABĪ: VIDA E OBRA}

1. Pensamento arabo-islâmico e as fontes de Ibn 'Arabī .............................................. 6

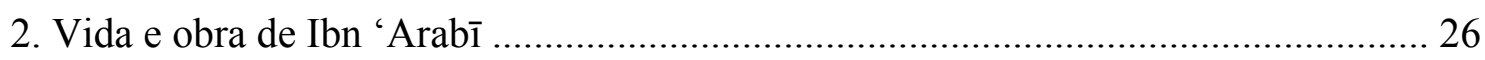

3. Sobre o Kitāb fușūṣ al-hikam (O livro dos engastes das sabedorias) ........................ 33

\section{CAPÍTULO II}

\section{A METAFÍSICA DO REAL NO LIVRO DOS ENGASTES DAS SABEDORIAS}

1. Introdução: Ibn ‘Arabī apresenta Kitāb fușūṣ al-hikam ........................................... 42

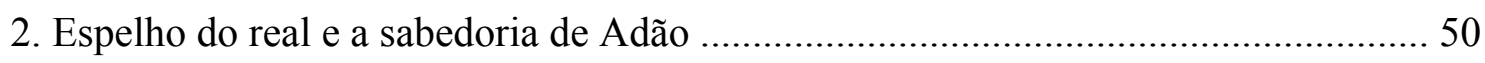

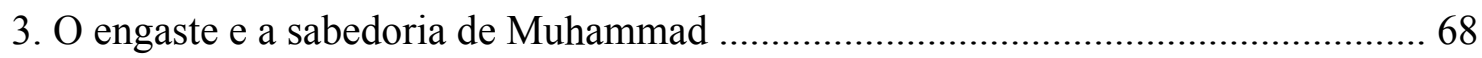

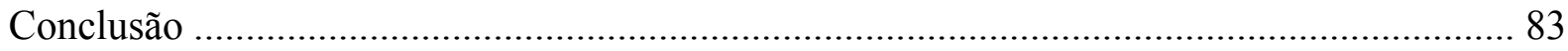

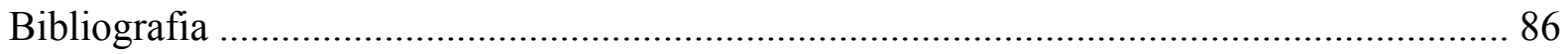


Tabela de Transliteração

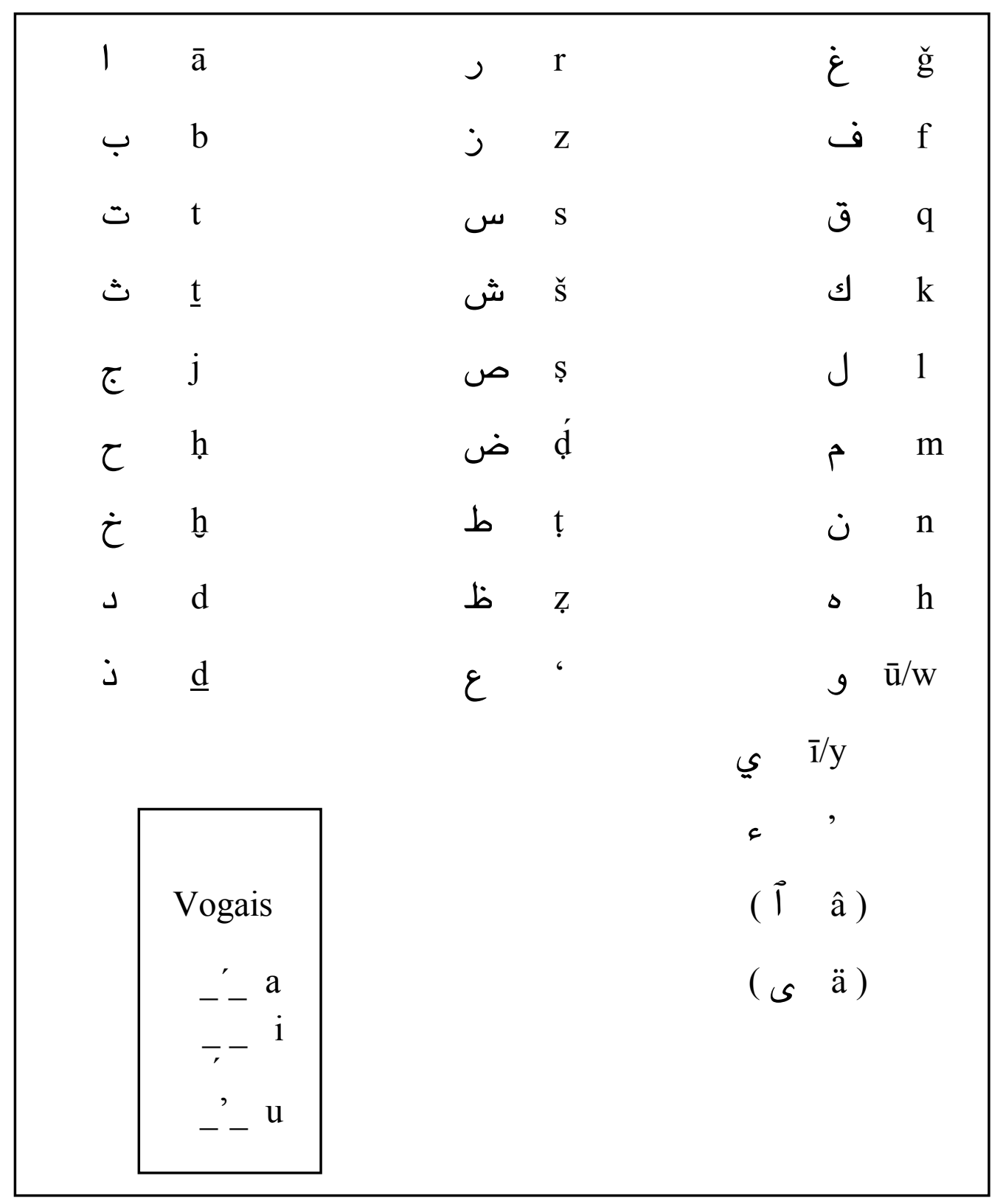




\section{Introdução}

O presente estudo origina-se - se é que é possível falar em uma origem, sendo ainda mais difícil determiná-la cronologicamente - da observação de alguns fatos e questões que, há algum tempo, vêm chamando a minha atenção. Alguns deles são direta ou indiretamente contemplados aqui, outros permanecem como questões cujas respostas ainda não me foi possível esboçar, mas cuja força mobilizou-me para a realização desse trabalho porque, para respondê-las, descobri, desde a elaboração do projeto de mestrado, que era necessário responder a questões anteriores, ainda mais fundamentais. Indicadoras de um caminho a percorrer, essas questões, que chamarei de questões mobilizadoras, conduziram-me ao encontro de certas evidências, a partir das quais pude considerar a importância de estudar especificamente o Kitāb fușūs al-ḥikam (O livro dos engastes das sabedorias) de Ibn 'Arabī.

A primeira dessas questões mobilizadoras diz respeito à dúvida, que ainda permanece comigo, sobre qual seria a diferença entre as noções de alma e de espírito? $\mathrm{O}$ homem seria dotado de corpo, alma e espírito ou, tão somente, corpo e espírito e, a palavra alma seria um termo equivalente à palavra espírito? E por que, para alguns autores, essa diferença é tão fundamental e, para outros que tratam do mesmo assunto, nem mesmo parece existir? Questões que começaram a adquirir importância, inicialmente, por dois motivos, primeiro porque, há alguns anos, antes de elaborar o projeto de mestrado, eu começara a ler alguns livros de James Hillman ${ }^{1}$, estudioso de Henry Corbin, um importante comentador de Ibn 'Arabī.

Hillman, adota como perspectiva fundante de todo o seu processo de investigação o que denominou como psicologia arquetípica, a perspectiva da alma, ou seja, interessa-lhe falar, pensar, atuar sempre a partir da perspectiva da alma, permanecer nela, considerando a linguagem e os modos de expressão que sejam próprios da alma, autodenominando-se "porta-voz da alma", no sentido de quem procura sempre falar a partir dela e diferenciando-a de espírito, uma vez que, segundo Hillman, a linguagem do espírito, bem como suas necessidades, diferenciam-se da linguagem e das necessidades que seriam próprias da alma. Ocorre que, para isso, Hillman apoia-se, recorrentemente, em inúmeras passagens de Corbin sobre os livros de Ibn 'Arab̄̄.

Pode-se dizer, com isso, que o que Hillman conheceu de Ibn 'Arabī foi, de modo geral, bastante determinado pelos comentadores de Ibn 'Arabī, muito mais do que pelos

\footnotetext{
${ }^{1}$ James Hillman (1926-2011), psicólogo americano pós-jungiano.
} 
próprios escritos do autor. Ibn 'Arabī, por ele mesmo, não me parece ter operado tal diferenciação, ao contrário, na busca espiritual, tão cara para esse autor, se a alma está em questão é no sentido das categorias aristotélicas a partir das quais os animais e vegetais, por exemplo, são substanciados a partir de uma forma e de uma matéria - nesse caso, alma e corpo. A alma corresponderia, portanto, ao que constitui, em um ser particular, sua forma determinada. A compreensão do conceito de alma no Sobre a Alma de Aristóteles, assim como no Livro da alma de Avicena, não me parecem ambos estarem na mesma chave de leitura que é apresentada por muitos teóricos que se servem dos comentadores místicos da obra de Ibn 'Arabī, e, com base neles, continuam produzindo suas pesquisas sobre o tema até os dias de hoje. Mas essa é uma investigação de fôlego que exigiria muito mais do que comporta esse trabalho e, além disso, como dito anteriormente, faz-se necessário cumprir etapas anteriores.

Até aqui, citei meu interesse por James Hillman, para contextualizar minha aproximação em relação a Ibn 'Arabī, mas, também, como indicador de como o pensamento de Ibn 'Arabī vem sendo cada vez mais importante nos estudos em diversas áreas da produção do conhecimento, na literatura, na psicologia, na filosofia, na mística, na história do pensamento, na arte, etc. E, dado que em certo momento dos meus estudos em psicologia arquetípica vi-me impulsionada pela necessidade de conhecer melhor o pensamento de Ibn 'Arabī para que questões formuladas, tanto por Hillman, pelos comentadores de Ibn 'Arabī e por meio das leituras que fiz desse autores, pudessem ser melhor esclarecidas, fazia-se necessário que eu buscasse compreender de onde vêm as linhas que estruturam os discursos contemporâneos que se fundamentam nas idéias de Ibn 'Arabī. O que, mais uma vez, permanecerá como tarefa futura, pois ao me deparar com os escritos de Ibn 'Arabī, compreendi que muito ainda há para ser realizado no sentido de compreendê-lo com mais propriedade para depois, quiçá, empreender os estudos na direção daquilo que permanece, por hora, suspenso.

A segunda questão coloca-se no sentido de que quanto mais lia os livros de Corbin, como por exemplo, Temple et contemplation ${ }^{2}$ e L'imagination créatrice dans le sufisme d'Ibn 'Arabi $\bar{l}^{3}$, mais interessada ficava pelos temas e questões que surgiam. No entanto, em seus livros, Corbin apresenta uma profusão vertiginosa de questões por página, que remetem sempre a outras e mais outras e mais outras questões, cada vez mais esotéricas, mais secretas, mais inacessíveis para aqueles que, supostamente não seriam tão bem dotados

\footnotetext{
${ }^{2}$ Corbin, Henry. Temple et contemplation. Paris: Entre Lacs, 2006.

${ }^{3}$ Corbin, Henry. L'imagination créatrice dans le soufisme d'Ibn 'Arabī. Paris: Entre Lacs, 2006.
} 
de um conhecimento espiritual ou místico quanto seus comentadores. Qualquer que seja o assunto, o tema, o aspecto ou o problema apresentados nesses dois livros e em outros de Corbin, muito raramente eles são trabalhados no sentido de apresentar elementos que favoreçam maior clareza, uma certa delimitação e circunscrição da problemática, de forma a fornecer ao leitor chaves que o permitam, de fato, começar a abrir e compreender melhor um texto de Ibn 'Arabī.

Ao contrário, notava eu que, quanto mais lia, menos tinha condições de saber ou de apontar e descrever o que eu estava, de fato, lendo e entendendo. Tinha sempre a sensação de estar me movendo em um solo movediço e cujo horizonte também não era possível avistar. Os fundamentos, assim como as explicações de certas afirmações da doutrina de Ibn 'Arabī, sempre eram remetidos a outros estudos e dalí a outros e assim por diante, de forma que a questão não atingia nem mesmo uma formulação justa, apreensível, enfim, uma formulação enquanto tal. A promessa das explicações que responderiam à tantas dúvidas que ficavam em aberto permanecia sempre como uma possibilidade futura. Os belíssimos, sedutores, imensos e profundos segredos esotéricos, não forneciam um porto, uma linha mestra por onde e como seguir, enfim, um apoio por meio do qual se pudesse ter a mínima sensação de que se pisava em terra firme, ainda que só fosse possível tatear, dando um passo de quando em quando.

Essa impressão continuou sendo reafirmada pela leitura de outros comentadores da escola francesa e inglesa como, por exemplo, Maurice Gloton, Roger Deladrière, Michel Chodkiewicz, Charles-André Gilis, Denis Gril, Titus Burckhartdt e outros, com os quais tomei contato. Com o tempo, percebi que a maioria dos comentadores que eu lia são místicos, comprometidos com uma determinada compreensão mística da qual se servem para a análise e comentários de vários livros de Ibn 'Arabī. O próprio Charles-André Gilis, tradutor e comentador do livro Kitab fușūṣ al-hikam, afirma, na primeira página do seu prefácio, o seguinte:

A apresentação do Livro dos engastes das sabedorias (Kitāb fușūṣ al-hikam) é, contudo, facilitada pela curta introdução de Ibn 'Arabī, que formula em algumas palavras a quintessência e a significação da obra. É necessário porém, no prefácio, encarar essa significação à luz do contexto tradicional de hoje, quer dizer, sob a perspectiva doutrinal iniciada por René Guénon e continuada por Michel Vālsan. Com efeito, o ensinamento desses dois Mestres contem elementos decisivos que esclarecem o sentido escatológico do presente tratado de uma maneira que os comentadores não 
puderam senão entrever, e que em toda e qualquer hipótese eles tiveram que disso se abster por razões de oportunidade cíclica. ${ }^{4}$

Trata-se, portanto, de comentários que tornam o texto ainda mais enigmático, segundo uma perspectiva que não é a própria perspectiva de Ibn 'Arabī, mas comprometida com um contexto doutrinal e com bases doutrinais que lhe são extrínsecos e, em muito, posteriores ao autor.

Foi justamente por essas razões que surgiu a perspectiva do presente estudo. Dada essa perspectiva da linha interpretativa de Ibn 'Arabī, amplamente desenvolvida e já consolidada, entendi que a contribuição que esse trabalho poderia trazer a mim mesma e a futuros estudiosos alinhava-se em outra perspectiva. Tal perspectiva tem como ponto de partida a leitura do próprio texto de Ibn 'Arabī sob uma ótica filosófica. Para isso, partindo das limitações que se seguem de uma leitora que não é iniciada nos mistérios sufis, proponho uma leitura de análise de um dos mais significativos livros de Ibn 'Arabī, Kitāb fuṣūṣ alḩikam, que me pareceu ser, de antemão, um livro fundamental para identificar algumas das chaves nas quais se encontra estruturado o pensamento do autor, do ponto de vista fílosófico, que elege como um de seus temas principais a profecia, cuja função é possibilitar ao ser humano o acesso à ciência mais elevada a partir das sabedorias reveladas pelos profetas. A profecia apresenta-se em Kitāb fuṣuṣ al-ḥikam como uma chave mestra capaz de abrir o sistema metafísico do autor.

Todavia, também não cabe aqui a pretensão de evidenciar todas as chaves possíveis por meio das quais se pode ler seus escritos ou esgotar a compreensão ao menos da obra escolhida para o presente estudo. Proponho uma análise de três partes desse livro, que considero fundamentais para o meu propósito: a Introdução escrita pelo próprio Ibn 'Arabī, o primeiro e o último capítulos, ambos apresentados no Capítulo II dessa dissertação. Leitura que se faz complementar a uma abordagem, em linhas gerais, do contexto cultural mais amplo, evolvendo a produção do pensamento filosófico, teológico e místico arabo-islâmico que formaram a ambientação teórica na qual o nosso autor encontrou-se imerso, o que se verifica no Capítulo I, seguido de uma breve introdução à vida e à obra do autor e de uma apresentação do Livro dos engastes das sabedorias, Kitāb fușūṣ al-ḥikam.

\footnotetext{
${ }^{4}$ Ibn 'Arabī, Muhyi-D-Din, Le livre des chatons des sagesses (Kitāb fușūṣ al-ḥikam). Tradução, notas e comentário, Charles-André Gilis. Ed. Al-Bouraq. Beirute. Líbano. 1997, pp 11 e 12.
} 


\section{CAPÍTULO I}

IBN 'ARABĪ: VIDA E OBRA

\section{Pensamento arabo-islâmico e as fontes de Ibn 'Arabī.}

Para que seja possível identificar os aspectos mais relevantes que compõem o pensamento e a linguagem discursiva tão próprios desse autor, os temas e as questões por ele tratadas, bem como tentar compreender o significado que isso tudo assume na história do pensamento arabo-islâmico, é preciso recuperar, ainda que brevemente, o contexto da constituição das três principais formas assumidas pela produção do pensamento no Islã que fizeram frente ao texto corânico, a saber, a filosofia - falsafa -, a teologia - kalām - e a mística dos sufis - șūfiyya -.

No entanto, não poderemos avançar nesse sentido, sem antes relativizarmos os possíveis sentidos aplicáveis ao termo "islâmico", problematização que acaba exigindo a mesma relativização dos termos "árabe" e "muçulmano". Vejamos porquê. Esses três termos não são termos equivalentes, ou seja, não podem ser tomados um pelo outro sem que todas as características essenciais de um deles permaneçam em outro. O termo "árabe", sendo geralmente utilizado no sentido da língua, da cultura, da política ou da etnia, não pode ser utilizado no sentido religioso, dado pelo termo "islâmico" que, por sua vez, designa o Estado, a cultura, mas não a etnia. O termo "muçulmano" refere-se aos adeptos da religião islâmica, sem a restrição de que esses sejam necessariamente árabes, pois há muçulmanos que não são árabes, assim como árabes que não são muçulmanos ${ }^{5}$.

Em princípio, o termo "árabe" se aplicou mais precisamente aos beduínos e à população nômade do deserto da Arábia, em oposição à população sedentária das cidades. (...) A partir do século VII d. C. / IH., com o surgimento do Islām, a aplicação do termo "árabe" começou a ganhar novas variantes. As conquistas que se sucederam logo após a morte do profeta Muhammad estenderam o império do norte da Índia ao sul da Espanha. Nesse primeiro período o califado esteve em poder dos árabes e, mesmo com a rápida expansão que se verificou, o termo "árabe" ainda se aplicava somente aos que falavam a língua árabe e descendiam de algumas tribos árabes. No entanto, quando outros povos foram adotando a língua e a religião dos árabes como, por exemplo, os sírios e os egípcios, o termo "árabe" começou a migrar em direção a

\footnotetext{
5 Attie Filho, Miguel. Falsafa: a filosofia entre os árabes: uma herança esquecida. São Paulo: Palas Athena, 2002. p.35.
} 
uma conotação mais próxima tanto do conceito religioso quanto do linguístico, pois tanto a língua, como a nova religião haviam sido geradas no seio do povo árabe.

Como bem assinalou Lewis ${ }^{6}$, "a partir do século VIII d. C. / II H. o califado foi se transformando gradualmente de um império árabe num império islâmico". O califado Omíada, que durou pouco mais de 100 anos, desde o estabelecimento do Islām, esteve em poder dos árabes. Em meados do século VIII d. C. / II H., a hegemonia árabe sobre o império começou a se perder. Os Abássidas, de origem persa, assumiram o califado e transferiram a capital de Damasco para Bagdá. Nessa época os interesses do império já não eram mais exclusivamente árabes. Esse foi um marco importante no distanciamento entre os conceitos "árabe" e "islâmico".

Atualmente o termo "árabe" é aplicado num sentido mais genérico, designando não somente os árabes que habitam a Arábia mas também os que habitam outros países tais como o Egito, Marrocos, Síria, Líbano e Iraque. Por outro lado os países árabes não designam a totalidade dos países islâmicos.

Na língua árabe, os termos Islām e "muçulmano" derivam de uma mesma raíz: salima. (...) Apesar de não haver uma regra rigorosa, o termo "islâmico" geralmente é usado no sentido das idéias e dos ideais contidos no Islām, ao passo que o termo "muçulmano" aplica-se com mais frequência à pessoa, ao sujeito concreto que pratica os ideais do Islām. (...) Por isso é mais comum encontrarmos "filosofia islâmica" e "filósofo muçulmano" e não o contrário. ${ }^{7}$

Quando aplicamos tais considerações a respeito desses termos sobre a produção medieval, seja ela filosófica, mística, teológica, literária ou científica, a problemática da escolha de qual dos termos seria mais adequado utilizar faz-se presente até os dias de hoje ${ }^{8}$.

M. Achena, tradutor de Ibn $\operatorname{Sīnā}^{9}$, discordou da posição de Anawati ${ }^{10}$, que considerou a dificuldade do emprego dos termos pensando na sua utilização para referir-se à produção filosófica, a falsafa, e realizou uma enquete na década de 1950, por ocasião do Congresso de Filosofia Medieval em Louvain, para tentar fixar a denominação desse período da História da Filosofia, adotando a expressão: "filosofia árabe". E Achena discordou também da contra-resposta dada pelo ministro iraniano 'Ali Asghar Hekmat na qual declara preferir "filosofia muçulmana" ao termo "filosofia árabe". M. Achena afirmou que os títulos "filosofia

\footnotetext{
${ }^{6}$ Lewis, B. Os árabes na História. Lisboa: Editorial Estampa, 1996, p.17.

${ }^{7}$ Attie Filho, Miguel. Falsafa: a filosofia entre os árabes: uma herança esquecida. São Paulo: Palas Athena, 2002. pp. 36, 37, 38 e 39.

${ }^{8}$ Sobre essa questão, ver: Ibidem, pp. 40-45.

${ }^{9}$ Avicenne, Le livre de science. Traduction du texte perse Danesh Nama par Mohammad Achena e Henri Massé. Paris: Les Belles Letres, 1986.

${ }^{10}$ Anawati, G. Études de philosophie musulmane, pág. 23.
} 
árabe" e "filosofia muçulmana" seriam assaz impróprios por apresentarem, ambos, o incoveniente de dizer o que não devem dizer e de não dizer aquilo que devem dizer. ${ }^{11}$

$\mathrm{Na}$ mesma época em que Anawati publicou as principais justificativas em defesa de uma ou outra posição,

"(...) Henry Corbin preparou a sua História da filosofia islâmica. A substituição do termo "muçulmano" pelo termo "islâmico" ganhou terreno nos anos seguintes. O projeto de Corbin pretendeu focalizar os autores islâmicos com ênfase na espiritualidade persa. Mesmo que, em princípio, parecesse mais consistente, o trabalho de Corbin deixou de fora os autores cristãos e judeus que escreveram em árabe e que estavam em estreita ligação com o pensamento dos autores muçulmanos. Em defesa da denominação da "filosofia islâmica", Corbin entendeu que o uso do termo "filosofia árabe" desde a Idade Média já não mais cabia nos dias atuais. Mesmo reconhecendo que o profeta Muhammad era árabe, que a língua da revelação foi o árabe e que, ao menos na base do islamismo, o elemento árabe foi preponderante, Corbin aludiu ao fato de que o termo "árabe" teria se alterado profundamente, significando um conceito étnico, nacional e político preciso, com o qual não coincidiriam exatamente o conceito religioso Islām nem os limites do seu universo.

No outro extremo, numa posição preferencial pelo termo "filosofia árabe", destacou-se $\mathrm{o}$ argumento de T. Hussein que lembrava que a maior parte dos textos foi escrita em árabe. Além disso, segundo ele, a ortodoxia religiosa dos falāsifa foi fortemente contestada e seria um paradoxo qualificar de "muçulmana" ou "islâmica" uma filosofia que se chocou frontalmente com certos dogmas da religião. (...) [Nesse sentido,] O próprio Anawati lembrava que a língua, não só do Alcorão, mas do comércio e da cultura, foi o árabe, adotada por muitos povos dominados pelo Islām. No entanto, apesar dos esforços, a conclusão de Anawati foi desalentadora:

"Os que tiveram a oportunidade de ler as respostas publicadas em nossa enquete puderam se dar conta de que, teoricamente, o problema colocado é insolúvel: não há um conceito adequado que abrace ao mesmo tempo o ponto de vista linguístico e o ponto de vista religioso. (...) Nós, mesmos com M. Gardet, tentando encontrar uma expressão sintética, "aberta" a todos os aspectos do problema, terminamos por chegar à fórmula: "filosofia medieval em terras do Islām"12.

Apesar de inovadora, a proposta não foi adotada com amplitude pela comunidade intelectual. (...) Certamente, mesmo que a enquete de Anawati tenha sido bem intencionada para definir os termos, o seu resultado contemplou, antes de tudo, a

\footnotetext{
${ }^{11}$ Ibidem, pág. 24.

12 Ibidem, pág. 85.
} 
aporia. Em todo o debate, observa-se que os critérios para nomear um determinado pensador, um determinado pensamento ou o conjunto das manifestações do período medieval oriental, foram quatro: o critério religioso, linguístico, geográfico ou étnico. Todos por sua natureza, se mostraram excludentes ou insuficientes. (...).

Uma outra opção que tem sido veiculada é o termo "filosofia em árabe", privilegiando a língua em que foi escrita a maior parte da falsafa. Porém, essa opção também não consegue abarcar as obras escritas em persa, em siríaco e em hebraico que, em alguns casos, foram fundamentais na história da falsafa. (...). ${ }^{13}$

Assim, os termos "islâmico" e "árabe" aqui utilizados, o são apenas na medida em que não pretendem superar tais limitações, mas conservam a aporia que é característica da confluência étnica, linguística, religiosa e geográfica determinante da complexidade presente na produção do pensamento filosófico, científico, místico, teológico e literário medievais. Do mesmo modo entenda-se a utilização do termo "arabo-islâmico" quando referente à produção do pensamento medieval, querendo com isso, pontuar a insuficiência do emprego de apenas um dos termos.

Dito isso, avancemos no sentido de pontuar algumas considerações, ainda que gerais, que permitam melhor caracterizar as correntes do pensamento arabo-islâmico que compõem o cenário epistemológico no qual se move nosso autor, conforme dito no início desse capítulo.

O momento histórico-filosófico do século XII e XIII no qual se desenvolve o pensamento de Ibn 'Arabī, abrange a idade de ouro da falsafa que emerge num cenário de maturidade da filosofia islâmica.

O termo falsafa significa "filosofia":

(...) num sentido mais específico, é entendido como o período clássico da filosofia entre os árabes, a partir do movimento de recepção e desenvolvimento da filosofia grega nas terras dominadas pelo Islām, circunscrito entre os sécs. VIII d.C. / II H. ${ }^{14} \mathrm{e}$ XII d.C. / VII H. Visto, portanto, como um segmento histórico da filosofia, a "falsafa" a qual me refiro é um movimento que se inicia com as obras de Al-Kindi e se encerra com a morte de Ibn Rushd sem que, com isso, sua continuidade seja comprometida, quando entendida de modo genérico. ${ }^{15}$

\footnotetext{
${ }^{13}$ Attie Filho, Miguel. Falsafa: a filosofia entre os árabes: uma herança esquecida. São Paulo: Palas Athena, 2002. pp. $41-45$.

${ }^{14}$ Hégira: as datas seguirão o presente formato, lembrando que o calendário muçulmano inicia-se no ano 622 da era cristã.

${ }^{15}$ Attie Filho, Miguel. Falsafa: a filosofia entre os árabes: uma herança esquecida. São Paulo: Palas Athena, 2002. p. 22.
} 
A atenção que pesquisadores hoje têm dedicado ao estudo da falsafa justifica-se pela importância que assume na cena histórica da filosofia.

Além dessa importância histórica, ressalte-se que a envergadura de suas teses traz elementos enriquecedores à cena do debate filosófico. Muitas vezes esse papel de primeira importância não é reconhecido com evidência, tanto pela dificuldade de informações como pela escassez de obras especializadas em nosso idioma, a esse respeito. $^{16}$

A falsafa, cujas teses datam dos séculos VIII ao XII d. C. / II ao VI H., é medieval e apresenta-se como uma novidade aos 1200 anos de filosofia precedente ${ }^{17}$ pois:

(...) até o sec. VIII d. C. a filosofia havia se desenvolvido principalmente entre os povos gregos, no interior do império romano e entre a cristandade do Oriente e Ocidente. A novidade repousa no fato de que, nesse panorama de povos e culturas, também passou a figurar o povo árabe. E assim, como o helenismo, quando absorvido por outras culturas, teve que se adaptar às características locais, o mesmo aconteceu no caso da falsafa. Os ingredientes da filosofia e das ciências gregas também se adaptaram à cultura e à religião dos árabes. Esse encontro resultou numa filosofia original e renovada que não se confunde com particularidades filosóficas anteriores. Além disso, a filosofia que havia sido um patrimônio praticamente exclusiva da língua grega, latina e siríaca, chegou, pela primeira vez, a ser escrita em língua árabe. ${ }^{18}$

Ainda que por muito tempo tenha sido empregada a expressão "filosofia árabe" para se referir à produção filosófica escrita em língua árabe, cabe atentar, como já foi dito, para a insuficiência da utilização dessa expressão ao significar uma produção filosófica que absorveu o que se produzia tanto no oriente, quanto no ocidente, por meio de sucessivas traduções realizadas do siríaco para o árabe, do grego para o siríaco, do árabe para o latim e que expressou, muito mais que a identidade étnica ou política a que corresponde a palavra "árabe", um modo de pensar próprio da cultura islâmica.

(...) O árabe literal é a língua da revelação corânica, a língua litúrgica da prece, a língua e o aparato conceitual utilizados por árabes e também por não-árabes, para edificar uma das literaturas das mais abundantes do mundo, aquela em que a cultura islâmica se expressa. (...) Os povos árabes, ou arabizados não são mais que uma fração minoritária na totalidade do mundo islâmico. ${ }^{19}$

\footnotetext{
${ }^{16}$ Ibidem, p. 22 .

17 Cf. Attie Filho, Miguel. Falsafa: a filosofia entre os árabes: uma herança esquecida. São Paulo: Palas Athena, 2002. p. 33.

${ }^{18}$ Ibidem, p.32.

${ }^{19}$ Corbin, Henry. Histoire de la philosophie islamique. Paris: Gallimard, 1964. pp. 11 e 12.
} 
Outra característica da falsafa bastante relevante é o fato de que a filosofia se deparou, nesse momento histórico, com uma nova religião.

O islamismo recebeu a falsafa pouco mais de 150 anos após o seu nascimento. (...) Foi a falsafa que se encarregou de fazer com que os princípios filosóficos se deparassem, pela primeira vez, com os dogmas da religião islâmica, o que foi sem dúvida, um novo desafio para ambas. ${ }^{20}$

A filosofia islâmica, seu modo de pensar, só pode ser compreendida se não se exigir um equivalente exato daquilo que se convencionou chamar no ocidente de "filosofia".

Mesmo os termos "falsafa" e faylasûf ${ }^{21}$, resultante das tradução dos termos gregos em árabe, e referentes aos peripatéticos e neoplatônicos dos primeiros séculos do Islām, não são equivalentes exatos dos nossos conceitos de "filosofia" e de "filósofo". A distinção, claramente marcada entre "filosofia" e "teologia" remonta, no ocidente, à escolástica medieval. Ela pressupõe uma secularização cuja idéia não poderia estar presente no Islām, pela simples razão de que o Islām não conheceu o fenômeno Igreja, com suas implicações e consequências ${ }^{22}$.

O estudo da obra de Ibn 'Arabī exige, além da compreensão do que é desenvolvido pela falsafa, olhos para a herança cultural que preexiste à falsafa, coexiste com ela e continua depois dela, isto é, continua depois da morte de Ibn Rushd e alcança um novo e original impulso com o pensamento de Ibn 'Arabī. Ou seja, o pano de fundo sobre o qual vale analisar o pensamento desse autor envolve a falsafa mas não se restringe a ela.

Desde o início o Islã conheceu a distinção entre a filosofia e a teologia, a falsafa e o kalām. O termo kalām significa discurso, linguagem ou palavra e aquele que é partidário do kalām denomina-se mutakallim, designando "aquele que discursa", "aquele que fala". 23

Logo após o estabelecimento do Alcorão, e mesmo antes das traduções das obras filosóficas gregas, o kalām já era uma realidade no mundo islâmico. Uma de suas características foi ter aplicado o raciocínio e a argumentação filosófica aos dogmas do islamismo. Nesse sentido, a abordagem do termo kalām aproximou-se bastante do sentido que damos ao termo "teologia" tomando por base a experiência do cristianismo. Ao se falar em teologia no Islām, é aos mutakallimūn, e não aos falasifā, que se encontram as referências. Desse modo os representantes do Kalām, enquanto se

\footnotetext{
${ }^{20}$ Attie Filho, Miguel. Falsafa: a filosofia entre os árabes: uma herança esquecida. São Paulo: Palas Athena, 2002, p. 33.

${ }^{21}$ No singular: filósofo.

${ }^{22}$ Corbin, Henry. Histoire de la philosophie islamique. Paris: Gallimard, 1964. pp 13 e 14.

${ }^{23}$ Attie Filho, Miguel. Falsafa: a filosofia entre os árabes: uma herança esquecida. São Paulo: Palas Athena, 2002, pp. 49 e 50.
} 
basearam na revelação como ponto de partida para a reflexão filosófica, podem ser considerados os mais próximos dos pensadores cristãos dos primeiros séculos do cristianismo.

(...) Guardadas as devidas particularidades, assim como em nossos manuais da "história da filosofia" figuram os padres da igreja cristã, os mutakallimūn podem ser incluídos na "história da filosofia no Islām". Isso está bem colocado por Badawi ao dividir sua obra em "filósofos puros" e "filósofos teólogos". Os primeiros são os falasifa, pois prescindem dos dados da fé para argumentar, e os segundos são os mutakallimūn que se utilizam dos argumentos lógicos para justificar o que é sabido pela revelação. Diz Badawi: "quem diz filosofia diz pensamento essencialmente racional. Assim nos limitamos ao estudo dos sistemas racionalistas, tanto em teologia especulativa como em filosofia pura ${ }^{24}$, ou seja, tanto no kalām como na falsafa. Um dos exemplos dessa distinção é que as vias da razão levaram, muitas vezes, $A l-F \bar{a} r a \bar{b} b \bar{l}$, Ibn Sinna e o próprio Ibn Rushd a construírem sistemas que se confrontaram com os dogmas da religião. Por essas razões é que a falsafa não é teologia islâmica e se mantém fiel à tradição da filosofia herdada dos antigos. ${ }^{25}$

Considerando que a história intelectual dos árabes começou com o nascimento do Islã, antes da palavra revelada, a tradição da poesia e da literatura, sendo transmitidas oralmente, continham as regras sociais, políticas, religiosas e morais que eram aplicáveis dentro dos limites de cada grupo. ${ }^{26}$

Os regionalismos e as regras estanques de cada tribo, de cada clã e de cada família foram sendo ultrapassados pelo chamamento do Profeta para a união dos árabes. A mensagem do Alcorão permitia uma visão universal que deveria ultrapassar os regionalismos tribais. Porém, mais que mensagens religiosas de oração e devoção, o Alcorão trazia, também, uma série de princípios, regras de conduta e a própria lei pela qual a comunidade deveria se guiar e o crente, em particular, deveria seguir. A fonte corânica, somada à tradição das ações e decisões atribuídas a Muhammad, precisariam ser bem compreendidas para que fosse atingido o termo da fé. Isso, obviamente, não era tarefa fácil, e como bem assinalou Hernandez, "os primeiros doutos na religião islâmica (...) encontraram sérias dificuldades na hora de aplicar o Alcorão a toda a ordem social do Islām" ${ }^{27}{ }^{28}$

\footnotetext{
${ }^{24}$ Badawi, A. Histoire de la philosophie islamique, pág.5.

${ }^{25}$ Attie Filho, Miguel. Falsafa: a filosofia entre os árabes: uma herança esquecida. São Paulo: Palas Athena, 2002 , pp. 50 e 51.

${ }^{26}$ Attie Filho, Miguel. Falsafa: a filosofia entre os árabes: uma herança esquecida. São Paulo: Palas Athena, 2002, pág. 123.

${ }^{27}$ Hernandez, M. C. História del pensamiento en el mundo islamico, pág. 99.
} 
Do conjunto do texto corânico e das narrativas da tradição, a primeira geração de sábios muçulmanos procurou extrair princípios jurídicos gerais e morais que fornecessem uma trilha segura aos crentes. Desse modo nasceram, inicialmente, três tipos de ciência: da leitura; da exegese; e da jurisprudência; formando uma base mínima de exegese no início do islamismo. No campo jurídico, por exemplo, uma classe de sábios deu início ao uso da analogia e do julgamento independente para as matérias indecisas, dando surgimento a quatro escolas jurídicas nas quais a jurisprudência muçulmana se baseou: a de 'Abū Hanīfa (m. 767 d.C.) e a de $A l-S a \bar{f} \bar{\imath}$ (m. 820 d.C) foram as mais liberais e rivalizaram com as de Mālik Ibn 'Anas (m. 795 d.C) e a de Ahmad Ibn Hanbal (m. 855 d.C. $)^{29}$

A exegese do texto sagrado foi, para os primeiros pensadores islâmicos, bastante desafiadora, uma vez que a palavra sagrada - sendo vista como única e perfeita -, dependendo do entendimento dos homens, recebia múltiplas e controversas interpretações. Por isso a abordagem do texto corânico buscou os princípios propriamente teológicos para fundamentar sua posição e a teologia - o Kalām - tornou-se o principal meio para sistematizar explicações referentes aos dados da revelação e da tradição. Esse mesmo movimento também foi decisivo no modo como o islamismo definia seus limites face ao paganismo, ao judaísmo e ao cristianismo. $^{30}$

Como já foi dito, o meio em que a filosofia islâmica se deu conheceu uma série de dificuldades, mas não as mesmas encontradas na cristandade, ela se fez "refletindo sobre o fato fundamental da profecia e da revelação profética com os problemas e a situação hermenêutica que esse fato fundamental implica. Assim, a filosofia assume a forma de uma "filosofia profética", determinando profundamente a teologia especulativa e a mística. A herança cultural pré-existente à falsafa, que da falsafa se beneficia e a ela sobrevive, refere-se à filosofia profética do xiismo - sob suas duas formas principais: o imamismo duodecimal e o ismaelismo - à mística, que engloba diferentes aspectos do sufismo como a experiência espiritual e a teosofia ${ }^{31}$ especulativa que, por sua vez, encontra-se enraizada no xiismo.

\footnotetext{
${ }^{28}$ Attie Filho, Miguel. Falsafa: a filosofia entre os árabes: uma herança esquecida. São Paulo: Palas Athena, 2002, pág. 123.

${ }_{29}$ Attie Filho, Miguel. Falsafa: a filosofia entre os árabes: uma herança esquecida. São Paulo: Palas Athena, 2002, p. 124.

${ }^{30}$ Attie Filho, Miguel. Falsafa: a filosofia entre os árabes: uma herança esquecida. São Paulo: Palas Athena, 2002 , pp.124 e 125.

${ }^{31}$ Termo usado por neoplatônicos como Porfírio e Proclo, para indicar o conhecimento das coisas divinas, proveniente da inspiração direta por Deus.
} 
O modo de apreensão islâmico da transcendência retoma elementos essenciais da concepção religiosa judaico-cristã, do budismo, do mazdeísmo ${ }^{32}$, para dizer alguns, sem deixar de configurar-se na sensibilidade própria dos nômades do deserto. Os homens para quem Muhammad pregava, que foram convertidos em vida ou logo após a sua morte, eram homens do deserto. A concepção religiosa do Islã, implicada em um desenvolvimento teórico bastante complexo de suas idéias, encontra-se na origem dos seguintes saberes particulares, ou ciências religiosas, que surgiram quase que simultaneamente e acabaram assumindo teorizações bem diversas ao longo do tempo: a recitação corânica ( 'ilm al-qirā'āt), tradição ${ }^{33}$ ('ilm al-hadīt) ${ }^{34}$, a exegese ('ilm al-tafsīr), o direito ('ilm al-fiqh), a teologia especulativa ('ilm al-kalām) e a mística ( 'ilm al-tasawwuf). O primeiro desses saberes a ser sistematizado foi o direito, seguido da teologia especulativa e da mística. E, nessa sistematização é importante notar as especificidades, na medida do possível, que a abordagem xiita adquire pois, embora em sistemas de pensadores como Ibn 'Arabī traços do xiismo e do sunismo se mesclem, permanece diferente do sunismo. ${ }^{35}$

A singularidade do xiismo pode ser notada de acordo com três causas: a dinástica, priorizada pelos historiadores árabes, a religiosa, pelos teóricos xiitas, e a cultural, preferida dos historiadores contemporâneos.

A raíz ideológica e religiosa pressupõe que a revelação de Deus à Muhammad foi devidamente codificada no Alcorão e, de modo geral, o sentido literal (zāhir) é evidente e Muhammad era o único eleito de Deus destinado a ser o último profeta enviado. Esse sentido literal é considerado como sendo o sentido puramente legal ou exotérico e, se isso está de acordo com a religião é porque repousa sobre o sentido esotérico (bātin), essa é a interpretação dos espirituais islâmicos conhecidos como sufis. Mas o que confere a novidade da interpretação xiita, é que a sua compreensão da revelação funda-se sobre conversas privadas entre Muhammad e 'Alī ${ }^{36}$. O que foi transmitido a 'Alī, foi a significação essencialmente verdadeira (haqīqa) da revelação, isto é, seu sentido rigorosamente esotérico.

\footnotetext{
${ }^{32}$ Idéias provenientes do zoroastrismo.

${ }^{33}$ A sunna.

${ }^{34} \mathrm{O}$ hadìt é uma palavra, um ato, até mesmo um silêncio revestido de uma importância particular na vida de um profeta. O hadīt torna-se um importante recurso para remediar certas insuficiências do Alcorão, dessa forma, torna-se assim, uma segunda fonte de jurisdição. (Hernandez, M. C. História del pensamiento en el mundo islamico, pág. 31).

${ }^{35}$ Hernandez, M. C. Histoire de la pensée en terre d'Islam. Paris: Desjonquères, 2005, pág. 41.

36 'Alī Ibn Abī Tālib, primo de Muhammad, viveram juntos desde criança, torna-se um dos primeiros fiéis e seus laços foram ainda mais reforçados pelo casamento de Alī com Fātima bint Muhammad, filha do profeta e de sua primeira esposa Khadīja.
} 
Assim, vê-se, por exemplo, o VI emir ${ }^{37}$ santo Ja 'far al-Sādiq atribuir a si mesmo as seguintes palavras:

Nossa causa [= nosso ensinamento] é a Verdade e a Verdade da Verdade. Ela é o exotérico (al-zāhir), o esotérico do exotérico (al-bātin al-zāhir) e o esotérico do esotérico (al-bātin al-bātin); ela é o segredo, o segredo de uma coisa que permanece velada; ela é um segredo residente em um arcano. ${ }^{38}$

Na ocasião da morte de Muhammad, em 632, grande parte das tribos da Arábia já se havia ligado ao Islã. Muhammad não deixou herdeiros. Foi seu amigo íntimo e o mais fiel dentre seus companheiros, Abū Bakr, quem passou a dirigir a comunidade muçulmana. Abū Bakr, foi o primeiro califa, faleceu em 634, mas designou em vida seu sucessor, outro companheiro do Profeta, 'Umar, assassinado em 644, dez anos depois do falecimento do primeiro califa. O terceiro califa Utmān, foi assassinado em 656, e as razões de sua morte nunca foram esclarecidas.

Os partidários de 'Alī (al-s̄̄ 'a 'Alī: origem da palavra sī'a: shī 'ismo) não reconheceram, de fato, o califado de 'Utmān. Quando da disputa do quarto califa para a qual 'Alī foi designado, os Marwanides (família de Marwān ibn al-Hakam) exigiram dele uma prova irrefutável que provasse que ele não esteve em nada implicado no crime de morte de Utmān. 'Alī não soube ou não pôde fornecer tal prova que, segundo a tradição pré-islâmica, exigia um solene juramento. Esse fato, somado à atitude da jovem viúva do Profeta 'Aisa bint Abū Bakr e de seus antigos companheiros, Talha e al-Zubayr, agravaram a situação de modo que o conflito degenerou em guerra civil e aqueles que eram próximos a 'Utmān não reconheceram jamais 'Alī (656-661 d. C.), pegando em armas. ${ }^{39}$

As primeiras dissidências islâmicas datam desse período, o primeiro combate em 657 não resolve o conflito, alguns parecem ter se abstido da decisão, são os chamados mutazilitas. Dentre os partidários de 'Alī, os fiéis mais rigorosos à antiga legalidade, julgam a arbitragem um sacrilégio e abandonam seu posto - daí o nome kharijitas (aqueles que se

\footnotetext{
${ }^{37}$ O termo de $A m \bar{\imath} r$ - "emir" - não é encontrado no Alcorão, trata-se de um termo pré-islâmico, muito corrente, que significa comandante. Conforme a tradição arabo-islâmica, trata-se de um sobrenome cuja função é a atribuição de um título honorífico, assim, o sobrenome de Amīr logo cessa de ser pessoal tornando-se um segundo título mais importante e imponente que o subtítulo Khalīfa. Sobre o termo escreve Ibn Rushd: "No seu sentido primeiro, o termo "rei" designava aqueles que governavam a sociedade. É evidente que a arte pela qual as comunidades são governadas não pode ser realizada plenamente se todas as qualidades necessárias ao governante encontram-se nele reunidas, como é o caso do legislador profeta. Essa palavra designava originalmente aquele que detinha dessa maneira a virtude intelectual pela qual as regras práticas nasciam no interior das nações e das comunidades. Esses nomes de filósofos, de rei e de legislador são sinônimos, do mesmo modo que o de imām, imã em português, uma vez que imām é para os árabes, aquele cujos atos seguimos. (Crone, P. e Hinds, M. God's Caliph. Religious Authority in the First Centuries of Islam, Cambridge, 1986.)

38 'Awā, 'A., L'esprit critique des frères de la pureté, Beyrouth, 1948.

${ }^{39}$ Hernandez, M. C. Histoire de la pensée en terre d'Islam. Paris: Desjonquères, 2005, pp. 47 e 48.
} 
retiram) - constituindo assim uma dissidência mais puritana. A arbitragem realiza o racha a favor da tese do assassinato do califa, dada a ausência de uma justificação legal para a sua morte. Seus partidários, desse modo, proclamam califa, o governador da Síria Mu'āwiya, de quem descende a disnastia dos Omíadas. ${ }^{40}$

Nesse período, a sede do califado era Medina, transferindo-se para Kufa, no Iraque, no califado de 'Alī. O primeiro califa, Abū Bakr, em menos de um ano após a morte do Profeta, unificou a Península Ibérica em torno do islamismo. Formou-se um exército de fiéis que não tardou a ultrapassar as fronteiras do norte da Arábia e mostrar sua força frente aos territórios dominados pela Pérsia sassânida e pelo Império Bizantino. Os motivos que levaram a sucessivas vitórias dos árabes sobre os persas e os bizantinos são tema controverso pelo fato da superioridade dos exércitos destes últimos. Além do impulso da fé, a promessa de ricos espólios levou os beduínos a se alistarem sob as bandeiras dos califas num período em que nem Bizâncio e nem a Pérsia - que há muito combatiam entre si pela supremacia na Ásia Menor e no Oriente Próximo - pareciam crer numa real possibilidade do mundo árabe. (...).

Vale lembrar que nesse período a Pérsia vivia um certo vácuo de poder. De 629 a 632 d.C. sucederam-se oito soberanos. A entrada de muçulmanos em territórios dominados por Bizâncio como, por exemplo, a Síria, foi facilitada tanto pelas querelas religiosas dos monofisitas como pelos árabes que lá viviam e, há tempos, já mantinham relações comerciais com a Arábia. Também o Egito, devido a profundas dissensões, a chegada dos árabes teve uma acolhida favorável. Com a conquista do Egito, encerrou-se a primeira fase da expansão muçulmana. Em seguida, iniciaram-se as conquistas marítimas que puseram fim à supremacia bizantina no Mediterrâneo. O último califa desse primeiro período, 'Ali, genro do Profeta, sofreu muita pressão política e transferiu a capital para Kufa, no Iraque. Nesse período, a unidade do mundo muçulmano e a supremacia árabe passaram por grandes transformações e divisões internas. $^{41}$

Voltando ao exame dos fatores que particularizam o xiismo, o fator étnico e cultural pode ser verificado através da expansão do xiismo. O xiismo foi adotado por grande parte dos muçulmanos novos (tribos turcas que se fortaleceram com a queda dos Sassânidas, estabelecidas dois séculos antes na Ásia Central, cujos chefes tribais turcos convertidos e

\footnotetext{
${ }^{40}$ Ibidem, p.48.

${ }^{41}$ Attie Filho, Miguel. Falsafa: a filosofia entre os árabes: uma herança esquecida. São Paulo: Palas Athena, 2002, pp.113 e 114 .
} 
agindo de acordo com suas convicções, uniram suas tropas às tropas conquistadoras islâmicas que avançaram até o mar Aral, à costa indiana e aos confins da Índia e da China. ${ }^{42}$

Os diversos grupos étnicos como os mendes, os turcos, os indianos, conheceram formas religiosas e culturais de grande riqueza e alguns deles assim as conservaram por até dois séculos depois da hégira. O mazdeísmo era profundamente enraízado entre os persas e, no Irã, ainda se encontram alguns deles. O budismo, por sua vez, estendeu-se desde o Paquistão até as atuais regiões do Afeganistão, Uzbekistão e Turcomenistão. As tribos turcas, quando não adotaram um judaísmo ou um cristianismo fortemente marcados pela gnose, acabavam abdicando do animismo e do xamanismo a favor do budismo e do maniqueísmo. ${ }^{43}$

Assim, vê-se que o xiismo fora adotado por grande parte do novos muçulmanos, ou seja, por antigos budistas, gnósticos, mazdeístas, maniqueístas e outros. E é por isso que no pensamento xiita reaparecem antigas doutrinas como a sucessão de mundos, a luta do bem e do mal, a assimilação de Ahriman à Iblis (Satan), a ideia de um livro eterno que será o logos celeste, o homem arquetípico, as hierarquias dos anjos no céu e dos profetas sobre a terra, as tríades e as heptades gnósticas, o simbolismo das letras e ainda outros. ${ }^{44}$

Nesse sentido, o xiismo apresenta ideias características como o caráter espiritual do Alcorão, cuja significação esotérica é compartilhada por fiéis iniciados; a adoção de uma forma esotérica, isto é, secreta; uma certa consciência da queda do homem, com suas dúvidas espirituais que exigem um auxilio divino constante, função essa exercida pelos profetas, pelos enviados e, depois do selo que é Muhammad, pelos amigos de Deus; a franca ruptura com a dimensão social do califado, considerado como simples criação política; a exigência de uma explicação racional da tragicidade própria à dimensão humana; a necessidade de colocar um termo à sucessão dos imãs xiitas, seja pelo desaparecimento do sétimo imã Ismāīl ibn Ja'far - tese septimal -, seja pela ocultação do décimo segundo santo imã - tese duodecimal. ${ }^{45}$

O conhecimento da história das doutrinas da maior parte dos primeiros shiitas é bastante limitada e incerta. As mais antigas tradições remontam ao tempo do sexto e do sétimo imã, Ja'far al-Sādiq (morto em 765 d.C) e seu filho Mūsā al-Kāzim (719-799 d.C.). O fato mais certo é a origem da dissidência septimal, a ruptura entre os partidários do sétimo

\footnotetext{
${ }^{42}$ Hernandez, M. C. Histoire de la pensée en terre d'Islam. Paris: Desjonquères, 2005, p. 54.

${ }^{43}$ Ibidem.

${ }^{44}$ Ibidem.

${ }^{45}$ Ibidem.
} 
imã, Ismā'îl ibn Ja'far - os ismaelitas - e aqueles do sétimo santo imã, seu irmão Mūsā alKāzim - os duodécimos. ${ }^{46}$

Assim como se pode considerar que o sufismo seja proveniente do xiismo dada a hipótese da origem budista assim como da existência de uma espiritualidade mística mazdeísta que tenha sido incorporada pelo Islã, a concepção xiita do caráter necessariamente esotérico da interpretação do Islã, bem como a existência de certos textos que afirmam ser o sufismo originário do xiismo - pode-se também, por outro lado, considerar a ideia de que o sufismo encontra seus fundamentos no sunismo dadas as potencialidades espirituais inerentes ao Alcorão, a aproximação das espiritualidades cristãs e islâmicas de figuras místicas inclassificáveis como al-Hallaj e Ibn 'Arabī e a classificação de outros sufís como sufis extremistas e ainda paralelos ulteriores, como a possibilidade da influência da mística islâmica sobre a cristã do século XVI, notadamente sobre São João da Cruz. ${ }^{47}$

De todo modo, três elementos essenciais da espiritualidade islâmica tornam-se evidentes: a abordagem literal dos dados de toda revelação junto ao seu sentido legal, a via mística (tarīqa) e a verdade espiritual essencial subjacente (haqīqa). Semelhante ao monarquismo ${ }^{48}$ cristão, as confrarias islâmicas constituem o mais vivo testemunho da recusa de uma interpretação legalista, literal e ritual do gesto religioso. O que significa dizer que o sufismo constitui uma via original, compatível tanto com as posições xiitas como com as sunitas. E, certamente, o sufismo é ele mesmo uma via (tarīqa) espiritual: a devoção pelos santos imãs fornecia uma direção (tarīqa) não implicando com isso o pertencimento a uma confraria particular. Uma leitura exclusivamente xiita do sufismo permanece insustentável pela enorme influência do pensamento místico de Ibn 'Arabī sobre a espiritualidade xiita. Apresentar o xiismo e o sufismo como dois movimentos espirituais sem qualquer conexão até o século XIII, ou apresentar o sufismo sunita como absolutamente independente do xiismo, é uma posição cientificamente inviável. ${ }^{49}$

O Islã, como muitas outras religiões, possui dois aspectos, o aspecto exterior que se pauta na lei revelada (sari'a) aplicando-a na observância dos ritos e atos de devoção; e o aspecto interior: que seria o sufismo (al-tasawwuf), cuja atitude religiosa predominante é dada pela crença na unicidade divina (al-tawhīd) que é expressa no Alcorão, datando do

\footnotetext{
${ }^{46}$ Ibidem, pp. 55 e 56.

${ }^{47}$ Ibidem, p. 125.

${ }^{48} \mathrm{Ou}$ modalismo: termos equivalentes dados à interpretação da Trindade cristã que consiste em ver nas três pessoas divinas, três modos ou manifestações da substância divina única. Interpretação que sempre foi considerada herética pela Igreja cristã, que insistiu na igualdade e na distinção das pessoas divinas. No século III, o Monarquismo foi sustentado por Scotus Erigena e de Abelardo. (Nicola, A. Dicionário de Filosofia. São Paulo: Martins Fontes, 2007).

${ }^{49}$ Ibidem, p. 126.
} 
primeiro século da hégira. Diferentemente do crente comum, o sufi busca libertar-se do senso comum, da multiplicidade e do imediato buscando a essência e transcendendo o múltiplo. Enquanto via interior do Islã, o sufismo consiste, de modo geral, na série de experiências pessoais, na busca da aproximação do ser e da realidade última, procurando atingir a consciência dessa realidade, fundindo-se e aniquilando-se nela. Portanto, nesse sentido, o sufismo é, no Islã, a via que conduz do individual ao universal, do múltiplo ao universal, da aparência à essência e, dessa forma, reúne-se às outras tradições místicas como o hinduísmo, o taoísmo, o budismo, a mística cristã, o mazdeísmo, a mística judaica, a cabala.

Assim, o sufismo ocupa-se das verdades universais da doutrina e do conhecimento que dela se pode ter, aspecto metafísico que explora qual a natureza da realidade e o lugar que o homem assume dentro dela, ocupando-se também da realização do homem através dos diferentes graus da via; operando, desse modo, nos planos cosmológico, metafísico e nos planos daquilo que modernamente se convencionou chamar de ontológico, escatológico e psicológico.

O sufismo estabelece certas exigências para se chegar ao grau de purificação desejado como o respeito às 1 leis ${ }^{50}$, que por sua vez ditam ao menos cinco regras fundamentais, como a afirmação da unidade divina e reconhecimento de seu enviado, mensageiro e profeta Muhammad, cinco orações rituais cotidianas, jejum purificador do Ramadã, peregrinação à Meca e o dízimo destinado ao pobre. Também são exigências, além da observância e respeito às leis, a prática religiosa esotérica, a iniciação e o método, sendo as duas últimas provenientes do guia, considerado como o representante de uma linhagem direta que remonta ao Profeta. ${ }^{51}$

A corrente mística sufi, representada por uma série de ascetas e sábios, nasceu ainda no século VII d. C, no século IX recebe uma primeira formulação intelectual com a escola masarrita ${ }^{52}$. Somente a partir dos séculos X e XI, com teóricos como Abu Sa 'id, Hujwiri, al-Sarraj, Qushairi, é que ela foi consolidada e institucionalizada e apenas um século depois, em XII, é que vemos surgir as primeiras ordens sufis. ${ }^{53}$

\footnotetext{
${ }^{50}$ Lei, cuja base é o texto corânico somado à sunna. A sunna representa a lei da tradição oral e vem complementar a lei escrita do Alcorão. Os problemas não resolvidos pelo texto corânico acabam sendo resolvidos com base no recolhimento de um certo número de tradições, chamados hadits, sobre os fatos e ações do Profeta e de seus discípulos imediatos, constituindo assim, uma maneira de agir com base em um padrão típico de comportamento que fundamenta tanto a prática como a teoria da ortodoxia muçulmana (a sunna).

${ }^{51}$ Kielce, A. O sufismo. São Paulo: Ediouro, 1988.

${ }^{52} \mathrm{Da}$ escola de Ibn 'Masarra, nascido em Córdoba, em 883. Quando morou em Meca, estudou o mutazilismo e o sufismo com um discípulo direto de al-Junayd, sua preocupação fundamental foi tentar harmonizar o senso especulativo com as verdades reveladas.

${ }^{53}$ Ibidem, p. 110.
} 
No princípio, os mestres reuniam em torno de si alguns discípulos que iam de um lugar ao outro em busca de conhecimento espiritual. Com o tempo, foram fundados conventos ou centros de oração destinados a abrigar os mestres e seus alunos. Esses centros recebiam nomes como zawiya, ribat e eram edificados junto ao túmulo de um grande santo. Centros assim existiam em Basra, Damasco, Alexandria, Palestina, Iraque, Síria, Korossan, mencionados desde o século VIII como lugar de retiro e orações, dedicado ao conjunto de práticas sufis, possibilitando uma vida monástica, embora não houvesse a imposição do celibato, sendo a maior parte dos sufis casados. Almería, entre os séculos X e XI, torna-se sede de um importante grupo esotérico sufi, de doutrina neoplatônica e, ao mesmo tempo, abrigava o grupo masarrita, de forma que tornou-se difícil depois, diferenciar o que era próprio de um ou de outro, pois passaram a apresentar muitos traços em comum. No século XII, os centros, que anteriormente eram isolados, começaram a se agrupar em confrarias ${ }^{54}$ mais amplas quando reconheciam mestres em comum, praticando, com isso, disciplina e métodos comuns. As maiores e mais importantes confrarias foram fundadas entre o séculos XII e XIV, com determinante influência de místicos que viveram antes desse período. ${ }^{55}$

A etimologia menos provável do termo sufi, embora seja aceita por alguns historiadores, é a que o faz derivar de $s \bar{u} f($ lã), por causa do manto de lã branca que portavam os místicos. De qualquer modo, e o que mais parece importar é que, há séculos, o particípio da quinta forma semântica da raíz swf, tasawwuf, é empregada para designar aqueles que fazem a profissão da mística assim como o labor e o saber que os caracterizam. ${ }^{56}$

Os teóricos do pensamento sufi acabam por incorporar grande parte das formas de saber herméticas, simbólicas e alegóricas do esoterismo antigo, isso porque o Islām estabeleceu-se em regiões e entre populações nas quais o esoterismo antigo fora mais intenso. Ainda que as religiões acabassem por exercer uma certa contenção ao esoterismo, muito dos aspectos das religiões acabavam por reforçá-lo, o que ocorreu também com o sufismo.

Os historiadores árabes sustentam que o primeiro sufi foi Hasan al-Basrī (21/643), teólogo especulativo moderado, mais um asceta que um místico, recomendava desdenhar o mundo, o exame de consciência e dizia que os homens espirituais se reconheciam através de seu desejo por Deus. É pelo silêncio e pelo vazio interior que o asceta experimenta a presença de um Deus que não pode definir-se senão como o vazio. Na tradição de Hasan al-

\footnotetext{
${ }_{55}^{54}$ Recebendo também a denominação de tarīqa.

${ }^{55}$ Ibidem.

${ }^{56}$ Hernandez, M. C. Histoire de la pensée en terre d'Islam. Paris: Desjonquères, 2005, pág. 127.
} 
Basrī encontra-se a figura de Rābi'a al-'Adawīya (morta em 185/801), poetisa do amor espiritual.

Outro grande místico, dentre os primeiros, foi Dū 1-Nūn al-Misrī, ("aquele que recebeu a ciência universal pela iluminação divina"), também conhecido como "O Egípcio" (morto em 245/859). Conhecia antigas línguas, como o hieróglifo, a ciência hermética, integrou ao sufismo conceitos neoplatônicos herdados do pseudo-Denys. Perseguido por suas ideias espirituais ousadas, notadamente por defender o caráter incriado do Alcorão, teve forte influência sobre al-Junayd, que foi, num certo sentido, seu discípulo, al-Hallāj e al- Kharrāz. A escola masarrita, sobre a qual teve grande influência, introduziu-o no ocidente e Ibn 'Arabī lhe consagrou um de seus escritos. Sua mística é uma especulação sobre a alegria inerente da oração espiritual, que permite ao iniciado adentrar os espaços celestes do paraíso onde se aperfeiçoa, regozijando-se no conhecimento intuitivo de Deus, a gnose suprema (ma'rifa). Alguns poemas de grande valor literário lhe são atribuídos, assim como a Carta ao amor divino. ${ }^{57}$

Abū Yazīd Bastāmī (morto em 874), originário da Pérsia, foi um dos primeiros sufis orientais a desenvolver um pensamento original. Segundo Bastāmī, o ser manifesta-se sob três formas, sob a forma do "Eu" (anā'iyya), sob a do "Tu" (antiyya) e sob a do "Si", ipseidade (hüiyya). A primeira é o mesmo, a segunda, o outro e a terceira o ser em si. É a partir do mesmo, ao qual opõe-se o outro, que se alcança a síntese em si. Eu e tu, humano e divino unem-se em um ato de amor recíproco, contemplação, que transcende todo o amor humano e assim o místico vê-se iluminado pela luz suprema. É nessa iluminação que se manifesta o segredo da ipseidade divina. Deus, assim, pode ver-se, não através dos olhos físicos, mas através do olho da verdade ('ayn al-haqq), sob uma forma que não é nem Ele mesmo, nem é distinto dele: verdade luminosa, eterna, na qual tudo subsiste, que não conhece limites, nem restrições, como em suspenso entre o $\mathrm{Eu}$ e o $\mathrm{Tu}$, aniquilados no ato de contemplação. ${ }^{58}$

A grande sistematização das obras de seus contemporâneos, assim como o desenvolvimento e enriquecimento das mesmas, foi feita pelo sufi oriental al-Junayd (morto em 910). Diretor de uma escola sufi em Bagdá, teve uma influência considerável tanto sobre a mística oriental islâmica quanto sobre a mística andaluz, Ibn Masarra estudou sob a orientação de um de seus discípulos. A ele também é atribuído o mérito de ter definido grande parte da terminologia sufi, notadamente os conceitos relativos à ascensão mística. Ele buscou,

\footnotetext{
${ }^{57}$ Hernandez, M. C. Histoire de la pensée en terre d'Islam. Paris: Desjonquères, 2005, pág. 129.

${ }^{58}$ Ibidem, p. 131.
} 
através da orientação sufi, um modo de equilíbrio entre a lei religiosa e a essência da religião, uma dependente do reconhecimento social das revelações proféticas, a outra, possuindo um valor espiritual permanente. Para al-Junayd, a essência da ascensão mística reside na experiência da radical unidade de Deus, através do aniquilamento ( $f a n \bar{a})$ de tudo aquilo que o separa Dele: a visão extática (ma'rifa) é o lugar da experiência do tawhīd, da tomada de consciência da unidade transcendente de Deus. Com isso, foi o primeiro a formular inteiramente a teoria mística sufi, seguindo um esquema que é reencontrado em todos que o sucederam. ${ }^{59}$

Assim, Junayd tornou-se o mestre sufi da maior parte das confrarias, também por ter encarnado a corrente moderada do amor divino e da união com Deus, tendo sido mais aceito pelas autoridades ortodoxas, propondo a lucidez e o discernimento como resposta à desmedida que acabou sendo identificada como relativa a Bastamī, considerado o primeiro sufi "embriagado de amor", cujas manifestações parecem ter causado grandes embaraços na comunidade sufi.

A sistematização da mística operada por al-Junayd é reencontrada no sufi iraniano Hakīm Tirmidī (morto em 898). Foram conservadas dele sua biografia espiritual, assim como algumas obras, notadamente, O livro do selo dos santos (Kitāb hatm al-awliyya), o qual Ibn 'Arabī comentou longamente. Tirmidī explica a união mística no mesmo sentido de al-Junayd, mas precisa que a ascensão que visa a união somente é possível a partir do sentido da mensagem profética.

Al-Hallāj nasceu em Fars, no Irã, em 858. Filho de pai mazdeísta, foi iniciado no sufismo por um discípulo de Dū l-Nūn, Sahl al-Tustarī, sufi particularmente interessado na "ciência mística das letras". Professava publicamente que a ascensão mística, longe de ser uma via reservada aos eleitos, apresentava-se como possibilidade para todos os homens, tendo como único fim, a união mística com Deus e a sua identificação com Ele através do supremo ato de amor, a santificação. Essa opinião provocou a hostilidade tanto de sufis que o acusavam de imprudência ao desvelar os segredos aos crentes comuns, como de teólogos que passaram a acusá-lo de panteísta. São suas essas palavras:

Eu sou Aquele que amo, Aquele que amo é eu.

Nós somos dois espíritos infundidos em um mesmo corpo.

Você me vê? você $O$ vê; você $O$ vê? você me vê.

Acabou sendo condenado por blasfêmia, e crucificado em 922. Entre Hallāj e Junayd, havia mais uma diferença de linguagem, na forma de expressão, e na atitude que propriamente uma

\footnotetext{
${ }^{59}$ Ibidem, p. 131.
} 
real diferença de pensamento, compreensão e experiência espiritual. Chibli, um eminente membro da escola de Bagdá, portanto da escola de Junayd, escreveu : "Hallāj e eu tínhamos uma única e mesma doutrina. Mas ele a publicou enquanto eu a escondia. A compreensão das palavras de Hallāj, colocadas em seu contexto, transformar-se-á numa fonte de força para o sufismo e será reencontrada em Ibn 'Arabī, na Epístola da unidade, em Attar, em Rumī, e outros.

Os séculos $\mathrm{X}$ e XI foram mais característicos como um período de consolidação e formalização da corrente mística sufi, numerosos tratados, baseados quase sempre no mesmo modelo, foram escritos nesse período. Todos apresentavam-se como uma antologia preocupando-se em abranger todos os domínios da doutrina, incluindo a definição dos estados e dos estágios da via, bem como os comportamentos e carismas dos quais o homem pode vir a ser objeto por parte de Deus. Tratados que demonstram a preocupação dos sufis em manter uma relação harmônica com a autoridade jurídica sem prejuízo da mística. Os sufis, eles mesmos, evitavam atrair a atenção para si, para evitar desvios de interpretações e possível condenação, a morte de Hallāj foi importante nesse posicionamento por parte dos sufis. Por isso, passou a ser tão necessário que a doutrina fosse definida com precisão.

Nesse sentido, o pensamento místico mais sistematizado, adquire nas mãos de Abû 'Abd Allāh al-Ghazāl, filósofo, teólogo e sufi, a reconciliação com a teolologia mais ortodoxa e com o direito canônico. Graças ao trabalho de al- Ghazāl, o sufismo alcança reconhecimento, consolida-se e expande-se com todas as suas confrarias, dando origem à literatura dos poetas persas como Attar, Rumī, Sohrawardi, Hafiz de Shiraz, dentre outros, e encontrando na voz de Ibn 'Arabī excepcional originalidade.

Ibn al-'Arīf, antes de tudo um sufi, com sólida formação filosófica e literária, nasceu em Almería, em 1088, formou-se no pensamento neoplatônico masarrita e passou a ensinar, desde muito cedo, em Almería, Saragoça e Valência. Estudou e escreveu sobre as vias de união extática com Deus, estabelecendo-as em uma hierarquia que abrange de dez a doze estações, a saber: a união mística, vontade, confiança em Deus, paciência, tristeza, crença, esperança, gratidão, amor e desejo, às quais acrescenta, às vezes, a penitência e a frequentação de Deus. Descrição apresentada no seu livro Beleza das sessões (Mahā almajālis), que parece ser reservado aos iniciados, as dez primeiras estações constituem o caminho na direção do que costumou-se chamar teosofia mística, que é, com o amor, a única estação específica reservada aos sábios que já estão estabelecidos na união com Deus no 
êxtase intelectual, pois aquele que alcança a união mística com Deus apropria-se do conhecimento intuitivo. ${ }^{60}$

Ibn 'Arabī foi determinantemente influenciado por suas idéias, com as quais entrou em contato quando esteve em Almería e conviveu com al-Ghazāl, discípulo direto de Ibn al-'Arīf. O conhecimento que Ibn 'Arabī tinha da escola de Almería, é atestado pelos seus próprios escritos. M. Asín Palacios recolheu onze passagens em As iluminações mequenses (Al-futūhāt al-makkiyya), comprovando a ligação de Ibn 'Arabī com essa escola' ${ }^{61}$ o conhecimento profundo de suas doutrinas, e sua filiação espiritual com Ibn al-'Arīf, a quem se refere algumas vezes como "nosso mestre espiritual". A influência de Ibn al-'Arīf, na obra de Ibn 'Arabī, pode ser notada através de alguns aspectos, como: a processão dos seres criados, a evocação esotérica como chamado divino, a aptidão da natureza humana para receber a profecia e ansiar à perfeição, a intuição, ou teosofia, como estação suprema do caminho da união com Deus, entre outros. ${ }^{62}$

A formação neoplatônica de cunho masarrita de Ibn 'Arabī também é identificada pela influência de Ibn Hazm, que é atestada pelos próprios escritos de Ibn 'Arabī reconhecendo dever-lhe algumas de suas concepções, pela sua fidelidade em matéria jurídica à escola zāhirita, cujo representante na Andaluzia era Ibn Hazm, pelo seu comentário do Tratado do direito muçulmano (Kitāb al-muhallā) e seu recolhimento de citações de Ibn Hazm e pela notável consideração a Ibn Hazm na sua teoria dos nomes divinos. ${ }^{63}$

Nos séculos XIV e XV o sufismo caracterizou-se sobretudo pelo desenvolvimento das confrarias, pela literatura, notadamente, poemas e comentários. Henry Corbin, historiador da filosofia islâmica e estudioso da obra de Ibn 'Arabī, refere-se a ele como um dos maiores teósofos visionários de todos os tempos que reuniu a filosofia dos falāsifa ${ }^{64}$, o kalăm $^{65}$ dos escolásticos, a ascese dos sufis na torrente de uma metafísica especulativa e de uma potência visionária sem precedentes. ${ }^{66}$

Desse modo, o estudo dos significados das sabedorias reveladas pelos profetas na hermenêutica de Ibn 'Arabī apresentados em Fuṣūṣ al-hikam, faz-se consonante com aspectos fundamentais da teologia especulativa, da mística e, por outro lado, da falsafa ${ }^{67}$,

\footnotetext{
${ }^{60}$ Ibidem, pág. 646.

${ }^{61}$ Asín Palacios. «El Místico murciano Abenarabī, I, Autobiografia cronológica», Boletín de la Real Academia de la Historia, 87 (1925), pp.96-172.

${ }^{62}$ Hernandez, M. C. Histoire de la pensée en terre d'Islam. Paris: Desjonquères, 2005, pág. 647.

${ }^{63}$ Ibidem, pág. 648.

${ }^{64}$ Filósofos.

65 Teologia.

${ }^{66}$ Corbin, Henry. Histoire de la philosophie islamique. Paris: Gallimard, 1964. pp 402 e 403

${ }^{67} \mathrm{O}$ termo falsafa significa "filosofia" e será melhor apresentado ainda no início desse capítulo.
} 
evidenciando originais configurações assumidas por nosso autor, em um período histórico significativo e de grande contribuição para a história do pensamento arabo-islâmico.

Todas as preocupações, fundamentos e recursos de linguagem apontados até aqui, foram empenhados por Ibn 'Arabī que, utilizando-se de um estilo de incrível poder de síntese e tratando sempre de forma inspirada sobre a palavra revelada dos profetas, alcança clara universalidade de pensamento, recusando falar com exclusividade para os sufis, mas dirigindo-se também aos filósofos, teólogos, juristas e a quem interessar seus escritos, a quem cujo exame atento considerá-lo digno de crédito $^{68}$.

Ao fazer uso da tradição filosófica, do sufismo e da teologia, Ibn 'Arabī constrói um estilo que parece moldar-se no cruzamento dessas vozes, um estilo correspondente ao contexto histórico, plenamente habitado por essa polifonia, do que vem a ser a Córdoba dos séculos XII e XIII, na qualidade de um importante centro de estudos, cujas raízes foram apontadas ao longo desse capítulo, para que assim sejam evidenciadas algumas das conexões epistemológicas estruturantes do sistema ackbariano.

${ }^{68}$ Cfr. Ibn 'Arabī, Las iluminaciones de la Meca. Trad. Victor Pallejà de Bustinza. Madrid: Ediciones Siruela, 2005, pp. 62 e 63. 


\section{Vida e obra de Ibn 'Arabī}

O pensamento de Ibn 'Arabī insere-se na filosofia neoplatônica, na teosofia especulativa, na metafísica do sufismo, na tradição abraãmica, herdeiro da filosofia antiga, do pensamento grego, do mundo iraniano, da tradição judaico-cristã,

(...) não obstante, é genuinamente árabe, já que está profundamente enraizado na cultura e na língua árabe, e plenamente islâmico, pois suas referências permanentes são os fundamentos das escrituras islâmicas, o Corão e a Sunna. Em virtude desse mesmo fundamento islâmico, sua obra oferece um pensamento de alcance universal que reconhece todos os profetas do ciclo histórico, [assim como] as diversas tradições reveladas (...). Pode-se afirmar que, integrando em seu pensamento razão e revelação, unidade e diversidade, Ibn 'Arab̄i foi o primeiro entre os autores da tradição abraãmica a expor de modo compreensível e explícito, tanto em estilo discursivo como em linguagem alusiva, os fundamentos que tornam possível e requerem um diálogo criativo e conciliador entre as diferentes crenças e culturas. ${ }^{69}$

Ainda que menos da metade dos escritos a ele atribuídos não tenham sobrevivido aos nossos dias, restando cerca de 400 títulos dos quais poucos receberam a primeira publicação impressa e algumas traduções, mesmo assim, podemos assistir um interesse sempre crescente em relação aos estudos, traduções e pesquisas dedicados a sua obra e aos temas por ele tratados.

Abû Bakr Muhammad Ibn 'Ali ibn Muhammad al-Hātimī al-Ta'î ibn al'Arabīi ${ }^{70}$, a quem se atribui os epítetos Muh'yī al-Dīn, "o vivificador da religião”, Ibn Aflātûn, "filho de Platão" e al-Sayh al-Akbar, "o maior dos mestres", nasce em 28 de julho em 1165 d.C. $/ 560$ H., em Murcia. Aos oito anos (1173 d.C/568 H.), muda-se para Sevilha após a ocupação da Murcia pelos almóadas, onde passa a estudar o Corão, o Hadīth, a Sāri'a, gramática, retórica e recebe uma boa educação literária, jurídica, filosófica e teológica. Seis anos depois, em Córdoba (na Andaluzia), conhece Averróis através de seu pai, muito amigo do filósofo. Em 1185 d.C/581 H., Ibn 'Arabī torna-se membro de uma confraria (tarīqa), praticando assiduamente os métodos ascéticos a fim de progredir rapidamente na via da perfeição espiritual. Deixa a Espanha e parte para o norte da África, em 1193d.C./509H, estabelecendo-se, primeiramente, em Tunis onde conhece o xeique al- Mahdawī a quem dedica, anos mais tarde, sua obra $A$ epístola do espírito da santidade (R̂̂h al-quds). Em

\footnotetext{
${ }^{69}$ Beneito, Pablo. El viaje interior entre Oriente e Ocidente: la actualidad del pensamiento de Ibn 'Arabī. Madrid: Ed. Mandala, 2007, pp.8 e 9.

${ }^{70}$ Nome que geralmente recebe a abreviação de Ibn 'Arabī.
} 
regresso à Espanha (1195 d.C/592 H.), percorre Murcia, Granada, Almería, Córdoba, Marrakech, Fez, sempre escrevendo, conhecendo filósofos e homens santos, participando de conferências e sessões de discussões. Nessa época, em 1198, em Almería, torna-se amigo de Abû 'Abd Allāh al-Ghazāl, discípulo de Ibn al-Arīf, um dos místicos que mais o influenciou, até que regressa à Tunis, chegando ao Cairo e à Jerusalém em 1201 d. C./598 H. Em Meca, no mesmo ano, conhece Nizhām 'Ayn Ash-Shams, jovem sufi que inspira Ibn 'Arabī a escrever os poemas reunidos em O Interprete dos Desejos Ardentes. De 1204 d.C/601 H. a 1206 d.C./603 C. viaja para Bagdá, Mossul, Malatya, Hebron e Cairo, em que, diante da hostilidade da autoridade religiosa oficial, retorna a Meca percorrendo a Palestina. Em Konia (1210 d.C./607 H), encontra Sadr ad-Dīn, um de seus grandes discípulos a quem passa, mais tarde, a autorizar comentários de suas obras. Um ano depois, em Bagdá encontra o Sheikh Shihāb adDī (Umar as-Suhrawadī). A convite do rei Kay Kaus, permanece na Anatolia quase 5 anos, partindo, em 1223 d.C./620 H. para Damasco onde instala-se definitivamente até sua morte em 16 de novembro de 1240 d.C./ 838 H.

O conjunto de escritos de Ibn 'Arabī constitui uma enciclopédia filosófica, teológica, jurídica, hagiográfica, mística, ascética, literária e poética. ${ }^{71}$ Os livros e tratados escritos por Ibn 'Arabī são muito numerosos, ao menos 846 escritos são atribuídos a ele, dos quais 550 chegaram aos dias de hoje e apenas 400 são considerados autênticos ${ }^{72}$, compreendendo desde o extenso Futūhāt al-makkiyya, com milhares de páginas em árabe, distribuídas em seis grandes partes, 37 volumes e 560 capítulos, até inúmeros tratados de algumas poucas páginas. O trabalho de classificação de suas obras foi realizado por Osman Yahia em 1964, em Histoire et classification de l'oeuvre d'Ibn 'Arabī, que constitui ainda a primeira e única tentativa de avaliar a extensão de seus escritos.

A seleção dos títulos a seguir foi realizada a partir daqueles que podem ser considerados seus principais trabalhos, com base no que é frequentemente mencionado em seus livros, ordenada em títulos curtos, em ordem cronológica aproximada, embora não contemple a totalidade da sua produção ${ }^{73}$.

Contemplações dos mistérios sagrados (Masāhid al-asrār al-qudsiyya). Escrito em 1194-1195 d.C/590 H., na Andaluzia, dedicada aos discípulos do xeique 'Abd al-'Aziz alMahdaqī e ao seu primo por parte de pai, 'Ali b. al-'Arabī, em que o autor descreve uma

\footnotetext{
${ }^{71}$ Hernandez, M. C. Histoire de la pensée en terre d'Islam. Paris: Desjonquères, 2005, pág. 645.

${ }^{72}$ Fakhry, Majid. Histoire de la philosofie islamique. Paris: Cerf, 2007. p.276.

${ }^{73}$ Sobre a seleção das principais obras de Ibn 'Arabī, aqui identificadas, ver também: www.ibinarabisociety.org/intl/pt/maioresobras.html, que segue classificação das obras fornecida por Osman Yahia.
} 
sucessão de 14 contemplações, em forma de diálogos com Deus e visões divinas.

O governo divino (Al-tadbīrāt al-ilāhiyya). Escrito em quatro dias, esta obra foi provavelmente composta, pela primeira vez, antes do Masāhid, porém reescrita posteriormente. Enquanto estava hospedado na casa do xeique al-Mawrūrī, na Andaluzia, escreveu esta obra como resposta a um pedido do xeique para que explicasse o real significado da política secular.

Livro da jornada noturna (Kitāb al-Isrä'). Uma das mais importantes de suas primeiras obras, escrita depois de sua grande experiência visionária em Fez, em 1198 d.C/594 H., descreve, em prosa rimada, seu encontro com as realidades espirituais dos profetas nos sete céus.

O lugar das estrelas (Mawāqi' al-nujūm). Escrito em 11 dias em Almería, em julho de 1199d.C./595 H., para seu companheiro e discípulo Badr al-Habashī. É tido como o livro que explica o que todos os mestres espirituais precisam para ensinar; descreve os três graus de renúncia (isām), fé ('imānn) e verdadeira bondade (isām), de acordo com três níveis de realização. Inclui uma detalhada discussão de como todas as faculdades e membros do homem participam do louvor divino.

O Fabuloso grifo do oeste. Provavelmente a última das obras compostas na Andaluzia, escrita por volta de 1199 d.C/595 H., durante seu último ano na Espanha. A obra descreve em prosa rimada o significado da estação do Mahdi e do Selo dos Santos, como também o estágio da realidade muhammadiana. Foi feito com a intenção de ser um volume que acompanhasse o Tadbīrāt (O governo divino).

A constituição dos círculos abarcantes (Insā' al-dawā'ir). Escrito em 1201 d.C/598 H., em Túnis para Badr al-Habashī e al-Mahdawī, antes de deixar o Ocidente e ir para Meca. Descreve os fundamentos de sua metafísica, discutindo a existência e a não existência, a manifestação e a não manifestação, como também o estágio do ser humano no mundo, usando diagramas e tabelas.

O nicho das luzes (Miskāt al-anwār). Composto ao longo do ano de 1202/3 d.C/599 H., em Meca. Encerra uma coleção de 101 hadīth qudsī, dizeres divinos.

O adorno dos substitutos (Hilyat al-Abdāl). Escrito em 1203 d.C/599 H., no espaço de uma hora, durante a visita a Ta'if, para Badr al-Habasī. Descreve os quatro fundamentos da via: reclusão, silêncio, fome e vigília, como eles aparecem em termos físicos, como um tipo de abstinência e como são em sua realidade espiritual como condições do coração do servo.

A epistola do espirito da santidade (Rūh al-quds). Escrito em 1203 d.C/600 H., 
em Meca, para o xeique al-Mahdawī, é uma das melhores fontes para conhecermos a vida de Ibn 'Arabī na Andaluzia e as pessoas que conheceu. Contém três partes: uma reclamação sobre a falta de compreensão de muitas pessoas que praticam a via sufi, uma série de textos biográficos de mais ou menos cinquenta sufis do Ocidente, e uma discussão das dificuldades e dos obstáculos encontrados na via.

A coroa das epístolas (Tāj al-rasā'il). Escrito em 1203 d.C/600 H., em Meca, contém oito cartas de amor compostas para a Caaba, cada uma correspondendo a uma teofania do nome divino, observadas por ele durante o ritual dos giros.

A revelação em Mossul (Tanazzulât al-mawsiliyya). Escrito em 1205 d.C/602 H., em Mossul, descreve os segredos esotéricos dos ritos sagrados, ablução e oração, e como cada fase desses ritos diários está repleta de significado.

O livro da majestade e beleza (Kitāb al-Jalal wal-jamāl). Escrito em um dia, no começo de 1205 d.C/601 H., em Mossul, discute vários versos alcorânicos em termos de dois aspectos, majestade e beleza, aludindo ao terceiro aspecto que os integra, o equilíbrio da perfeição.

O que é essencial para o buscador (Kitāb kunh mā lā budda lil-murīd minhu). Também escrito no começo de 1205 d.C/601 H., em Mossul, delineia as práticas essenciais para alguém que está abraçando a via espiritual.

Alusões do Alcorão no mundo humano (Isārāt al-qur'ān fì 'alam al-insān). Escrito na Turquia, na primavera de 1205 d.C./601 H., foi concebido como um volume que acompanhava o A revelação em Mossul (Tanazzulāt al-mawsiliyya). Muito além de uma simples apresentação de passagens alcorânicas, é uma meditação ampliada de cada sura do alcorão.

Epístola das luzes (Risālat al-anwār). Escrito no verão de 1205 d.C/602 H., em Konia, na Turquia, em resposta ao pedido de um amigo e companheiro para que explicasse a jornada da ascensão a Deus e o retorno às criaturas. Descreve a busca espiritual em termos de uma ascensão contínua pelos vários níveis da existência e da sabedoria.

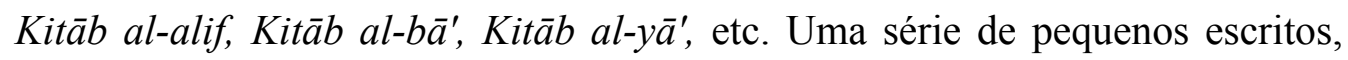
usando um sistema de numeração alfabética, iniciada em Damasco, em 1205 d.C/602 H., composta durante três anos ou um pouco mais, discute uma série de diferentes princípios divinos, tal como a unicidade (ahadiyya), compaixão (rahma) e luz (nūr).

O livro dos dias da obra de Deus (Kitāb ayyām al-sa'n). Composto por volta, ou um pouco antes de 1207 d.C/603 H., esta obra é uma meditação sobre a estrutura do tempo e os modos pelos quais as horas e os dias da semana se inter-relacionam e tem seu 
fundamento no verso alcorânico "Cada dia Deus está em obra".

Livro das teofanias (Kitāb al-tajalliyāt). Escrito um pouco antes de 1209 d.C/606 H., em Alepo (cidade no N.O. da Síria), descreve uma série de visões teofânicas, sobre assuntos como perfeição, generosidade e compaixão, baseadas nos insights da segunda sura do Alcorão. Estas visões frequentemente envolvem diálogos com santos que já morreram, tais como Hallāj, Junayd ou Sahl al-Tustarī. O objetivo da obra é instruir o buscador sobre o que pode acontecer em sua jornada espiritual.

Livro da aniquilação em contemplação (Kitāb al-fanā' fíll-musāhada). Escrito em Bagdá, provavelmente durante sua segunda estadia lá, em 1212 d.C/608 H.. É uma meditação ampliada sobre a sura 98, descrevendo a experiência da visão mística e a diferença entre as pessoas do real conhecimento e as pessoas do intelecto.

Intérprete dos desejos ardentes (Tarjumān al-aswāq). Compilado em 1215 d.C/611 H., em Meca, embora tenha sido escrito durante um longo período, com um subsequente comentário composto posteriormente, no mesmo ano, em Alepo. Contém 61 poemas de amor, dedicados a uma pessoa, Nizām, aludindo aos segredos reais do amor místico e da herança profética.

Termos técnicos sufis (Istilāhāt al-sūfiyya). Escrito em 1218 d.C/615 H., na Turquia, em resposta a um pedido de um querido amigo e companheiro. Contém 199 breves definições das mais importantes expressões de uso comum entre as pessoas de Deus.

O desvelamento dos efeitos da jornada (Kitāb al-isfār). O dia e o lugar da composição não são conhecidos. A obra é uma meditação sobre o significado da jornada espiritual em geral e das jornadas dos profetas, em particular. Estas jornadas não têm fim, nesse mundo e nos próximos e são descritas como "um lembrete do que você esqueceu que está dentro de você e em sua posse".

O livro dos servos de Deus (Kitāb al-'abādila). Escrito antes de 1229 d.C/626 H., provavelmente em Damasco. Contém 117 partes dedicadas a indivíduos chamados 'Abd Allāh, cada um descrito como sendo o "filho" de um particular nome divino e de um profeta. Aparentemente a obra tem relação a um hadīt que diz que um homem possui 117 características, e explica a realização destas características em termos dos nomes divinos.

O livro dos engastes das sabedorias (Kitāb fușūs al-ḥikam). Escrito depois de uma visão que teve durante um sonho com um enviado de Deus, através da qual recebera o conhecimento do Livro dos engastes das sabedorias, em 1229 d.C/627 H., em Damasco. Dedicado ao significado espiritual das sabedorias transmitidas por 27 profetas, começando por Adão e terminando com Muhammad. 
Catálogo de obras (Fihrist al-mu'allafāt). Escrito em 1229/1230 d.C/627 H., em Damasco, para Sadruddīn al-Qūnawī, este é o próprio catálogo de Ibn 'Arabī das obras que tinha escrito anteriormente a esta data.

Certificado para o rei al-Muzaffar (Ijāza lil-Malik al-Muzaffar). Escrito em 1234 d.C/632 H., em Damasco, para o governante da cidade, rei Ashraf al-Muzaffar, menciona 290 obras de seus mestres.

A linha do manto da iniciação (Kitāb nasab al-khirqa). A data e o lugar de composição são incertos, mas provavelmente foi em 1236 d.C/633 H., em Damasco. Descreve sua própria filiação espiritual e como chegou à via. Também inclui as iniciações que fez aos outros.

Orações para a semana (Awrād al-usbū'). A data e o lugar de composição não são conhecidos, embora tenham sido provavelmente compostas durante vários anos. Das muitas diferentes orações atribuídas a Ibn 'Arabī e ainda hoje extensivamente usadas, estas são talvez as mais conhecidas. São organizadas para cada dia e noite da semana, ao todo 14, escritas para recitação privada e para meditação.

O grande diwan (Al-dīwān al-kabīr). Escrito durante um período de muitos anos, e parece não ter sido completada até 1237 d.C/634 H., em Damasco, esta vasta coleção de poemas tinha aparentemente a intenção de conter toda a poesia que tinha escrito em diferentes manuscritos. Alguns, intitulados Dīwān al-ma'ārif, incluem uma introdução que descreve a visão que o levou a escrever poesia e uma dedicação a Badr al-Habasī. A edição impressa, baseada num diferente manuscrito, parece ser apenas um volume da obra toda.

As iluminações mequenses (Al-futūhāt al-makkiyya). Iniciada em Meca em 1202 d.C depois de uma visão e completada em sua primeira versão de vinte volumes em manuscrito, em dezembro de 1231 d.C/629 H.. Uma segunda versão, em 37 volumes, foi completada em 1238 d.C/636 H.. Contém 560 capítulos, em seis partes e tinha a intenção de ser uma espécie de "epítome espiritual" do Islã, cobrindo o período total de 560 anos, do início da era islâmica até seu próprio nascimento Trata-se de uma exposição detalhada de cada faceta da vida espiritual, incluindo comentários inspirados sobre cada sura do alcorão, explicações de hadīth, jurisprudência, cosmologia e metafísica.

Dentre seus escritos presentes nessa seleção, o Futthāt al-makkiyah (As iluminações mequenses) e Kitāb fușūṣ al-ḥikam (O livro dos engastes das sabedorias) destacam-se em termos de representatividade, o primeiro constitui-se numa série de tratados, 
o segundo, objeto do presente estudo ${ }^{74}$, apresenta-se como um dos pilares de sua metafísica, tendo sido escrita em Damasco, no ano de 1229 d.C/627H., quando Ibn 'Arabī tinha 64 anos.

O Kitāb fuṣuṣ al-hikam é a obra que trata da forma mais direta e aprofundada do significado dos profetas e das sabedorias por eles transmitidas, ao teorizar sobre o papel que assumem no cenário da criação e sobre a possibilidade de acesso ao conhecimento da essência divina ou do real. Em verdade, os sentidos de algumas das questões essenciais da filosofia e da mística islâmicas, como a relação entre o criador e a criatura, a possibilidade de conhecer a realidade primeira, a revelação da sabedoria divina, a profecia, a ciência das demais ciências, são apresentados nesse livro através de um pensamento estruturado metafisicamente. 


\section{Sobre o Kitāb fuṣūṣ al-ḥikam (O livro dos engastes das sabedorias)}

É nesse cenário vário proporcionado pelo pensamento arabo-islâmico, em que convergem acontecimentos históricos e culturais, já apresentados na introdução, que se pode analisar uma das principais obras de Ibn 'Arabī, Kitāb fușuṣ al-ḥikam, que reúne, em termos neoplatônicos, a dinâmica e os princípios metafísicos fundamentais propostos pela sua filosofia, servindo como base para a compreensão de grande parte de seus outros escritos que, muitas vezes, aprofundam temas e questões nela apresentados.

Kitāb fușūṣ al-ḥikam, O livro dos engastes das sabedorias, que na tradução francesa ${ }^{75}$ intitula-se Le livre des chatons des sagesses, leva-nos inicialmente à observação de alguns aspectos que se evidenciam, de antemão, nas palavras e nas relações entre as palavras que compõem o título do livro. Começando pela última palavra, al-hikam, que pode ser traduzida por as sabedorias, nota-se que a sabedoria é apresentada nessa obra no plural trata-se, pois, das sabedorias que se apresentam a partir de uma dinâmica fundamental presente na imagem do engaste, dinâmica que permeia e marca significativamente a concepção ackbariana desenvolvida nesse livro.

Sobre a palavra engaste - termo que utilizo para a tradução em português da palavra francesa chaton $^{76}$ - vale considerar que a palavra fușūs, em árabe, possui outros significados como joia, núcleo, gema, substância, junção de dois ossos ou de cartilagens. Dentre os vários significados árabes para a palavra fușu, adoto a escolha de Gilis pelo termo chaton, pois parece ser a palavra que melhor expressa a dinâmica através da qual as sabedorias tornam-se manifestas pelos profetas, tema do presente livro.

O engaste é a parte de uma joia, um anel por exemplo, construída para receber uma determinada pedra, um receptáculo que obedece rigorosamente às configurações da pedra preciosa que será fixada no anel. Engastar é a ação de embutir, fixar ${ }^{77}$, encravar pedras, ou encaixar a extremidade de uma peça em outra. Assim, configura-se a ideia dos engastes que possibilitam engastar as pedras preciosas das sabedorias. Portanto, em decorrência da palavra "engastes", notamos que as sabedorias apresentam-se, ainda, sob um duplo aspecto: à cada sabedoria, seu respectivo engaste.

\footnotetext{
${ }^{75} \mathrm{Ibn}$ 'Arabī, Muhyi-D-Din, Le livre des chatons des sagesses (Kitāb fusūs al-hikam). Tradução, notas e comentário, Charles-André Gilis. Beirute, Líbano: Ed. Al-Bouraq, 1997. A partir daqui esse livro será citado Cf. Ibn 'Arabī, Le livre des chatons des sagesses, op. cit.

${ }^{76} \mathrm{Cf}$. tradução de Charles-Andrès Gilis, Les livre des chatons des sagesses, op.cit.

${ }^{77}$ Também no sentido de selar e a pedra preciosa seria, num sentido metafórico, um selo (al-khatam).
} 
Parece-me, portanto, tratar-se não apenas de um livro dedicado ao que, ou a quem, serve como engaste para cada uma das sabedorias nele consideradas, mas, conforme será tratado a seguir, esse parece ser o livro que, segundo o autor, revelaria o conhecimento de como a sabedoria divina manifesta-se no mundo, para os homens e através dos homens ${ }^{78}$, por meio dos engastes necessários para que cada aspecto dessa sabedoria possa ser manifesto enquanto sabedoria divina.

Mais adiante, ao nos depararmos com os vinte e sete profetas - nomeados e divididos nos vinte e sete capítulos da obra - será possível observar que, por ocasião de cada profeta, é examinada a especificidade da sabedoria por ele manifesta. De modo similar à sabedoria, a profecia não é tratada no Fuṣuṣs apenas como um aspecto singular e invariável. São os profetas, aos quais o autor faz referência nesse livro, que parecem fornecer o contexto para a análise de certas qualidades através das quais a sabedoria apresenta-se.

Considerando a atenção que o autor dedica a cada um dos profetas contemplados no Fușuș, as características gerais, de cada um deles, parecem convergir na direção de uma qualidade ou atributo essencial, que o autor identifica, no interior de cada capítulo, como sendo o atributo que um profeta particular veio, por excelência, manifestar.

Desse modo, o atributo parece ser, justamente, aquilo que particulariza e determina existencialmente um profeta. Ocorre que, enquanto certos atributos da sabedoria são cuidadosamente examinados - na medida em que determinam, particularmente, um profeta - a sabedoria, no singular, da qual decorrem todos os atributos, não é nunca esquecida pelo autor. Ibn 'Arabī, continuamente, incita o leitor a conciliar essa dupla perspectiva: a perspectiva que leva a pensar o mundo a partir da essência, que é una, e a perspectiva que leva a pensar o mundo a partir da existência determinada, sempre múltipla.

Assim, Ibn 'Arabī considera que todo atributo é, antes de tudo, um atributo do real $^{79}$, inerente à essência do real e, quando um atributo torna-se manifesto, isso significa que a essência assumiu uma forma determinada na existência. $O$ atributo, portanto, é o que qualifica a sabedoria que orienta um profeta particular. Por isso, cada atributo, escolhido pelo autor, para compor o título de cada um dos capítulos do Fușuș, parece exercer a função de um prisma, através do qual a sabedoria - ciência divina - pode ser conhecida em suas particularidades.

\footnotetext{
${ }^{78}$ Nesse caso, os profetas.

${ }^{79} \mathrm{O}$ conceito de al-haqq / o real é utilizado por Ibn 'Arabī para designar a realidade primeira.
} 
$\mathrm{O}$ real $^{80}$, ao assumir as formas determinadas que constituem a existenciação do universo, particulariza-se, manifestando-se em uma multiplicidade de existentes. Do mesmo modo, a sabedoria - no singular - atributo essencial do real, manifesta-se - no plural - por exemplo, em uma sabedoria transcendente, em uma sabedoria santíssima, em uma sabedoria profética, em uma sabedoria íntima, em uma sabedoria majestosa, e assim por diante, conforme apresentam os títulos dos capítulos que compõem o Fușuṣ.

Os vinte e sete capítulos do livro, originalmente, não receberam numeração ${ }^{81}$ tal como ocorre em outras obras do autor, mas nomes que apontam para diferentes qualificações atribuídas à sabedoria. Vejamos, a seguir, a sequência dos títulos dos capítulos.

1. "O engaste de uma sabedoria divina em um nome de Adão"; 2. "O engaste de uma sabedoria encantatória em um nome de Sete"; 3. "O engaste de uma sabedoria transcendente em um nome de Noé"; 4. "O engaste de uma sabedoria extremamente santa em um nome de Enoque"; 5. "O engaste de uma sabedoria perdida de amor em um nome de Abraão"; 6. "O engaste de uma sabedoria de verdade em um nome de Isaac"; 7. "O engaste de uma sabedoria sublime em um nome de Ismael”; 8. "O engaste de uma sabedoria espiritual em um nome de Jacó"; 9. "O engaste de uma sabedoria luminosa em um nome de José”; 10. "O engaste de uma sabedoria de verdade em um nome de Éber"; 11. "O engaste de uma sabedoria das aberturas em um nome de Selá"; 12. "O engaste de uma sabedoria do coração em um nome de Jetro"; 13. "O engaste de uma sabedoria da força intensa em um nome de Ló"; 14. "O engaste de uma sabedoria da citação existencial em um nome de Uzayr"; 15. "O engaste de uma sabedoria profética em um nome de Jesus"; 16. "O engaste de uma sabedoria toda-misericordiosa em um nome de Salomão"; 17. "O engaste de uma sabedoria da realidade atual em um nome de David"; 18. "O engaste de uma sabedoria da alma em um nome de Jonas"; 19. "O engaste de uma sabedoria secreta em um nome de Jó"; 20. "O engaste de uma sabedoria majestosa em um nome de João Batista"; 21. "O engaste de uma sabedoria real em um nome de Zacarias"; 22. "O engaste de uma sabedoria íntima em um nome de Elias"; 23. "O engaste de uma sabedoria de realização perfeita em um

\footnotetext{
${ }^{80}$ Tal como na nota anterior, o termo real designa a realidade primeira.

81 “(...) esses capítulos não são numerados, contrariamente aos que se encontram no Futūhāt. É apenas para fornecer comodidade que essa numeração aparece nos comentadores." Cfr. Ibn 'Arabī, Las iluminaciones de la Meca. Tradução e notas: Victor Pallejà de Bustinza. Madrid: Ediciones Siruela, 2005, (Prefácio do Tradutor) p.22.
} 
nome de Lukman"; 24. "O engaste de uma sabedoria do imã em um nome de Aarão"; 25. "O engaste de uma sabedoria da eminência em um nome de Moisés"; 26. "O engaste de uma sabedoria do sustentáculo universal em um nome de Khālid"; 27. "O engaste de uma sabedoria incomparável em um nome de Muhammad".

Os títulos, ao indicarem a estrutura de uma peça que está dentro, embutida na outra, evidenciam a dinâmica do engaste aplicada na relação que envolve a sabedoria referente a um de seus atributos essenciais e o profeta correspondente. Assim, cada capítulo de Kitāb fușuṣs al-ḥikam é dedicado a um profeta, começando por Adão, considerado no Islã como profeta, e concluindo com Muhammad, o qual acaba por "selar" 82 o exercício divino da profecia universal. A sequência dos profetas envolve Cristo e ainda outros profetas que a tradição judaico-cristã ignora, como Selá (Sālih). O autor elege da história, da vida e da obra de cada profeta, apenas os fatos e características que podem afirmá-lo de modo mais essencial. Isto é, apesar de serem encontrados na multiplicidade da história profética, os exemplos, metáforas e citações corânicas são utilizados na medida em que respondem essencialmente às questões implicadas na concepção de Ibn 'Arabī.

Todas as sabedorias às quais os títulos se referem de modo particular, revelariam a mesma essência do real que, para ser conhecida pelos homens, precisa sê-lo através de seus diferentes atributos. Dessa maneira, o autor, para tratar tanto da sabedoria como da profecia, escolhe fazê-lo através de vinte e sete atributos divinos.

A sabedoria, sendo um atributo essencial - isto é, necessário do real - existe independentemente de se tornar manifesta: o real é sábio e permaneceria sendo sábio caso não viesse a criar nenhum dos seres que existem na multiplicidade. É porque o real decide manifestar-se que a sabedoria torna-se essencialmente profética. Desse modo, tem-se que a sabedoria divina já era essencialmente profética, antes mesmo do primeiro profeta ter nascido. Assim, em cada profeta, a sabedoria cumpre seu destino e pode ser conhecida por meio dos atributos divinos que torna manifestos. Em outras palavras, é na figura do profeta que o sentido da sabedoria divina e do mundo existente encontram-se reunidos. Por isso, nessa perspectiva, a referência dos engastes recai sobre os profetas, especificamente sobre os nomes que recebem os profetas, sendo, assim, os receptáculos perfeitos aos quais estão destinadas as pedras preciosas das sabedorias divinas.

\footnotetext{
${ }^{82}$ Uma vez que é considerado o último dos profetas.
} 
$\mathrm{Na}$ metafísica ackbariana, todos os nomes são atributos, infinitos nomes de infinitos atributos divinos. Mas o nome que pertence a um determinado profeta, no sentido que o autor quer indicar, não é o nome pelo qual o profeta foi chamado e ficou conhecido, é justamente o atributo essencial que rege a existência desse profeta para que possa ser, pelo profeta, manifesto.

Por exemplo, o profeta Abraão é determinado pelo atributo "amigo íntimo", o que faz com que a sabedoria, por meio desse atributo, seja manifesta e reconhecida como uma sabedoria perdida de amor, como o título do capítulo cinco anuncia. Aliás, a propósito desse atributo, o autor afirma o seguinte, a respeito da relação entre o nome e a essência divina:

$\mathrm{O}$ amigo íntimo foi designado por esse nome porque ele penetra e concentra tudo aquilo que a essência divina qualifica. O poeta disse:

Você me penetrou como caminho o espírito em mim

É por isso que o amigo íntimo foi designado por esse nome:

do modo como a cor penetra o objeto colorido, o acidente casa-se com a forma da substância, não do modo como um ser estendido ocupa um espaço. Mas porque Deus penetrou a realidade atual da forma de Abraão - sobre ele a paz!

A partir disso toda atribuição é válida; cada uma manifesta-se em seu lugar e nele respeita os limites. Você não vê que Deus manifesta-se com os atributos dos seres efêmeros? (...). E você não vê que o ser criado é manifesto com os atributos de Deus, do primeiro ao último? Todos lhe pertencem verdadeiramente, tudo assim como os atributos dos seres efêmeros pertencem verdadeiramente a Deus.

(...) Saiba que uma coisa não pode penetrar uma outra sem que esteja nela compreendida. Aquele que penetra é ocultado por aquele que foi penetrado. Esse último é o aparente, uma vez que o primeiro fica escondido no interior: ele é seu alimento, como a água, ao impregnar a lã, faz crescer seu volume. Se é Deus considerado como o exterior, a criatura permanece oculta nele; ela é o conjunto dos nomes divinos: sua audição, sua visão, o conjunto dos aspectos que lhe são atribuídos e de suas percepções. Ao contrário, se é a criatura considerada como o exterior, Deus permanece oculto e interior nela: ele é sua audição, sua visão, suas mãos, seus pés e o conjunto de suas faculdades assim como a lembrança de um hadīt autêntico. ${ }^{83}$

De acordo com essa passagem, o atributo "amigo íntimo" está presente em toda qualificação essencial e é, portanto, considerado como um aspecto da manifestação da substância, conceito utilizado pelo autor. Um profeta é a atualização, de modo particular, da sabedoria essencial. É assim que, por meio do atributo, o profeta pode manifestar a sabedoria essencial. E essa é a

83Ibn 'Arabī, Le livre des chatons des sagesses, op. cit. pp. 167 e 168. 
função primordial que os nomes assumem no sistema metafísico do autor, pois é através do nome que um ser particulariza-se, isto é, assume uma forma determinada.

Nesse sentido, pode-se compreender Majid Fakhry ${ }^{84}$ que, ao considerar a questão da profecia referindo-se diretamente ao logos, afirma que Ibn 'Arabī toma o logos como o ponto de partida da sua especulação, pois o profeta utiliza o verbo, assim como o criador ao criar o mundo e ao se manifestar através de seus nomes divinos.

No entanto, deve-se atentar ainda para uma importante observação que Ibn 'Arabī realiza no capítulo 22, ao comentar sobre o duplo aspecto da realidade que reúne a sabedoria e seu receptáculo, formando a joia. Nesse caso o receptáculo corresponde não exatamente ao atributo, mas a quem o atributo é destinado, a quem o atributo conforma na justa medida da sabedoria que o mesmo atributo pretende manifestar.

O espírito dessa sabedoria e sua joia é que a realidade se divide em duas expressões (correlatas): aquele que "produz o efeito" e aquele que o "sofre". O primeiro, considerando todos os pontos de vista, todo estado e toda dignidade, é Deus; o segundo, sob todos os pontos de vista, todo estado e toda dignidade, é o mundo.

Se um evento espiritual surge, religue toda coisa ao princípio que lhe corresponde, uma vez que aquilo que advém é sempre necessariamente a consequência de um princípio (...). ${ }^{85}$

Ou seja, a sabedoria, na sua unidade é uma expressão correlata da sabedoria que se revela na multiplicidade. As duas faces, o uno e o múltiplo, são duas faces do mesmo. O múltiplo não existe por si mesmo, ele é o efeito do uno, deriva dele. O uno é a causa, aquele que produz o efeito. Todo efeito sofrerá sempre os efeitos de sua causa, pois isso é existir para o efeito, uma vez que sua existência depende daquele que o produz. Desse modo, pode-se pensar nas sabedorias como efeitos e como "eventos espirituais" que, para serem conhecidas, deve-se buscar conhecer sua origem, sua causa.

Ibn 'Arabī desenvolve assim, uma metafísica cujos fundamentos podem ser apreendidos na introdução, no primeiro e no último capítulos da obra em questão. Em tais partes, os conceitos e suas relações mais importantes podem ser identificados através de uma leitura mais atenta, constituindo-se em verdadeiras chaves para a compreensão da obra ${ }^{86}$.

Com isso em mente, entendemos ser possível circular pela leitura dos outros vinte e cinco capítulos intermediários, observando como os conceitos, então centrais, vão

\footnotetext{
${ }^{84}$ Fakhry, Majid. Histoire de la philosophie islamique. Paris: Ed. du CERF, 2007. pp. 276 e 277.

85 Ibn 'Arabī, Le livre des chatons des sagesses, op. cit., p. 575.

${ }^{86}$ Os traços característicos da concepção metafísica do autor podem ser encontrados por toda a obra, mas apresentam-se significativamente mais sistematizados nas partes selecionadas para esse estudo.
} 
sendo explorados e aprofundados, adquirindo um contorno conceitual mais amplo. Desse modo temos uma visualização mais clara da dinâmica que anima um sistema complexo de pensamento, no qual parecem convergir perspectivas do que contemporaneamente podemos incluir em áreas como a cosmologia, a metafísica, a mística e a teologia.

Fuṣuṣ al-hikam, embora seja uma obra teórica e explicativa, conserva também o modo descritivo da linguagem, em larga dimensão simbólica e de forte poder imagético. Propriedades de um discurso formulado na confluência de inúmeras vertentes teóricas proporcionada pela cultura árabe e islâmica. Aspecto que não pode ser ignorado em um texto cuja estrutura enunciativa revela-se mesmo muito particular, parecendo escapar à tentativas de classificações apressadas ou comprometidas com visões encerradas em uma única ciência.

Nesse sentido, não se deve esperar da sequência dos capítulos um desenvolvimento linear que obedeça exclusivamente às exigências racionais de um discurso argumentativo. Ainda que haja sim, fundamentos e um sistema estruturados logicamente com constantes referências explicitas e implícitas à história da filosofia, propriamente à falsafa, nosso autor permanece livre dessas exigências sempre que elas representarem um limite que não coincide com os limites do conhecimento proporcionado pela experiência. Pois a ciência que pretende atingir, a ciência principal da qual nos fala, é a ciência da qual procede todas as outras, que tudo abarca, muitas vezes chamada por ele de ciência dos segredos ${ }^{87}$, ciência daquilo que pode permanecer invisível mesmo aos olhos do teólogo e do filósofo.

Se quisermos pensar, ainda assim, sobre a sequência dos capítulos, faz muito mais sentido recorrermos à uma lógica que não se encontra dissociada das imagens, metáforas e dinamismos simbólicos, examinemos brevemente esse aspecto.

Para continuarmos na dinâmica proposta pela imagem do engaste, o nome "misericordioso", por exemplo, é um atributo divino no qual estão contidos os demais atributos, nomes destinados a se tornarem manifestos e conhecidos. A sabedoria que o nome

\footnotetext{
87 Para Ibn 'Arabī, as ciências existem segundo três níveis, o conhecimento do intelecto que é todo aquele que pode ser obtido por evidência imediata ou pela indagação de um indício demonstrativo com a condição que se descubra a aparência real desse estado. O segundo nível de ciência é o conhecimento dos estados, o único caminho que conduz a ele é o da experiência imediata: não pode ser definido intelectualmente, nem existe qualquer prova conceitual que possa sustentar esse conhecimento. E o terceiro nível de conhecimento é a ciência dos segredos, também se trata de um conhecimento que está acima do estágio do intelecto, um conhecimento que advém do sopro do espírito santo no coração, sendo particular dos anjos, profetas, santos, e dos amigos de deus, pois é adquirido por comunicação divina, angélica ou profética. Aquele que conhece a ciência dos segredos sabe todas as outras ciências e as domina por completo, não sendo este o caso daquele que possui o restante das ciências. Os três níveis de conhecimento admitem tanto a verdade como o erro ou a mentira, por isso é sempre necessário verificar a veracidade da sua fonte, bem como a infalibilidade daquele que a comunica, como no caso dos profetas. Cfr. Ibn 'Arabī, Las iluminaciones de la Meca. Trad. Victor Pallejà de Bustinza. Madrid: Ediciones Siruela, 2005, pp. 56 e 57.
} 
misericordioso reúne, é a ciência dos segredos, a ciência muhammadiana que contem dentro de si todas as demais ciências, pois é considerada a ciência mais elevada.

Levando em conta que o atributo "misericordioso" exerce a função do engaste para a sabedoria, a sabedoria é primeira, pois dela surge o atributo misericordioso, uma vez que o atributo não teria realidade em si mesmo. Se adiantarmos aqui, também o fato de que esse é justamente o nome conferido a Adão, teríamos já um indício da razão, pela qual, o primeiro capítulo é destinado à sabedoria divina que encontra em um nome de Adão seu receptáculo.

No entanto, ao lermos o capítulo 27 notamos que o autor identifica a sabedoria mais alta ao profeta Muhammad, e que por isso afirma inclusive que Muhammad já era profeta enquanto Adão ainda era barro, podemos então perguntar por que o livro não inicia com o capítulo referente à Muhammad já que sua sabedoria é primeira em relação à sabedoria de Adão?

Ou seja, caberia pensar na sequência dos capítulos, de modo que o último fosse o primeiro e, aquele que é o primeiro, poderia segui-lo como o segundo capítulo do livro. Porém o sentido da original disposição ficará mais claro ao longo desse estudo, uma vez que Muhammad, embora essencialmente tenha sido concebido antes mesmo de Adão existir, ele representa também o selo da profecia e com isso, também, fecha o livro. Pois, essencialmente, não há qualquer profeta que subsista fora da sabedoria reunida na sabedoria muḥammadiana. Enquanto o capítulo destinado a Adão permanece sendo o primeiro, porque representa, justamente, a possibilidade da manifestação do real, ou seja, a própria possibilidade da manifestação da sabedoria muhammadiana.

Tudo isso faz sentido, se levarmos em conta que Ibn 'Arabī concebe o processo de existenciação como sendo originário de nomes que constituem atributos essenciais do real. Esses atributos estariam todos inicialmente contidos na essência mesma do real, mesmo num estado não manifesto. Iniciado o processo de existenciação, todo existente é uma manifestação de um nome que emana do real e, por isso, cada existente continua tendo a capacidade de emanar, de manifestar o que é próprio do real, já que, na sua origem, encontrase um nome essencial que funciona como um princípio existenciador ${ }^{88}$. Todo existente deve

\footnotetext{
88 Esse modus operandis da metafísica de Ibn 'Arabī, que pressupõe a essência procedente do real, continuamente sendo emanada enquanto realiza o processo de existenciação através dos nomes divinos, é por ele chamado de tajallī, literalmente transbordamento, mas é comumente traduzido por teofania e pode ser entendida como uma manifestação do logos da revelação profética, procedente do desejo criador de Deus através de seu "sopro de misericórdia"(nafas rahmanī). Nosso autor dedicou um livro inteiro sobre esse tema chamado Kitāb al-tajalliyāt, que recebeu tradução, introdução e comentários em francês de Stéphane Ruspoli. (RUSPOLI, S. Le livre des théophanies d'Ibn 'Arabī. Paris: CERF, 2000.)
} 
sua realidade ao que constitui sua essência, um existente que não seja o existente primeiro ou o real, não subsiste por si mesmo.

Cada atributo é definido por um nome e esse nome é aquilo através do qual o real manifesta-se de modo determinado. Dessa forma, os nomes assumem na metafísica do autor a função de, por um lado, manifestar os aspectos essenciais da sabedoria divina e reger todo existente que o possui e, por outro, permitir que a realidade essencial seja conhecida por meio de seus atributos.

Desse modo, seguem, respectivamente, a análise da introdução do Fuṣūs, escrita por Ibn 'Arabī, a análise do primeiro capítulo, a análise do vigésimo sétimo capítulo e, em seguida, a conclusão do presente estudo. Ao longo das análises serão feitas algumas referências, em notas explicativas, a outros textos do autor sempre que for necessário aprofundar o entendimento de algum conceito e possíveis implicações teóricas cujo desenvolvimento tenha sido realizado de forma mais minuciosa fora da obra em questão. 


\section{CAPÍTULO II}

\section{A METAFÍSICA DO REAL NO LIVRO DOS ENGASTES DAS SABEDORIAS}

\section{Introdução: Ibn 'Arabī apresenta Kitāb Fuṣūṣ al-ḥikam}

Ibn 'Arabī inicia o Kitāb fuṣūṣ al-hikam com uma introdução, na qual louva o nome de Deus e dedica-lhe o trabalho de escrita do presente livro. Observa, ainda, que este lhe fora revelado em sonho, por um enviado de Deus, o Livro dos engastes das sabedorias.

1. Em nome de Deus, o todo-misericordioso, o misericordiosíssimo.

Louvor a Deus que fez descer as sabedorias sobre o coração das palavras, na unidade da via axial, desde a estação mais antiga, apesar da diferença das formas e das regras tradicionais próprias às diferentes comunidades; e que Deus derrame sua graça unitiva e sua paz sobre aquele que assiste às aspirações espirituais graças aos tesouros da liberalidade e da generosidade pela palavra mais eficaz, Muhammad, assim como sua família! $!^{89}$

Inicialmente, é preciso levar em conta que a obra apresenta-se implicada em uma relação hermenêutica que parece transcender o próprio escrito, isto é, compreender a obra, envolve a compreensão do processo originário que a constituiu. Considerando tratar-se de uma introdução ao livro do Fuṣūṣ, o autor refere-se ao seu conteúdo como tendo uma procedência divina, descrevendo ainda o modo como as sabedorias, nele contidas, procederam de Deus.

As sabedorias, segundo o autor, teriam descido, de modo que poderíamos pensar que tenham percorrido distâncias que não sejam exatamente físicas, mas de outra ordem. Um percurso de natureza transcendente pois, como veremos ao longo desse estudo, o autor trata aqui de questões essencialmente metafísicas. Pois bem, as sabedorias teriam descido desde a estação mais antiga ou primeira - como dirá em outras passagens percorrendo "uma espécie de trecho" que se estenderia, ao menos, entre uma estação e outra. Por hora, sabemos apenas tratar-se de uma primeira estação, a mais antiga.

Desde já é importante ter em mente que, tal como outros autores da falsafa, Ibn 'Arabī está inserido numa tradição que perpassa

(...) os conhecimentos da época: lógica, física, matemática, metafísica, medicina, astronomia, música, psicologia, ética e política. (... $)^{90}$.

\footnotetext{
${ }^{89}$ Ibn 'Arabī, Le Livre des Chatons des Sagesses, op. cit., p. 27. Ressalte-se que todas as traduções para o português deste livro, aqui contidas, são nossas.

90 Attie Filho, Miguel. Falsafa: a filosofia entre os árabes: uma herança esquecida. São Paulo: Palas Athena, 2002. p.34.
} 
Desse modo encontramos, em seu pensamento, uma estruturação que se deve, em muito, ao que fora produzido pela falsafa, especialmente pela filosofia de Ibn Sīnā que, por sua vez, se vale da concepção de Al-Fārābī:

(...) do existente primeiro - que guarda semelhanças com o Uno de Plotino explicando seus atributos e o modo pelo qual, a partir d'Ele, derivou a aparente multiplicidade das coisas existentes no mundo. Numa formulação bastante original, de um ponto de vista islâmico heterodoxo, a metafísica da criação fez com que a unidade absoluta do existente primeiro fluísse de si a multiplicidade dos existentes mantendose, ainda assim, dentro dos limites da própria unidade e respeitando o axioma segundo o qual "do uno só procede o uno" (Ex uno non fit nisi unum), aliando as esferas planetárias para compor uma cosmologia. ${ }^{91}$

Tal como Al-Fārābī e Ibn Sīnā, Ibn 'Arabī absorveu o modelo ptolomaico das esferas concêntricas dentro do qual o universo encontra-se geocentricamente organizado. Deus ou o ser primeiro - ou ainda o equivalente em Ibn 'Arabī, o real -, por ser ao mesmo tempo inteligência, inteligente e inteligível, sábio e sabedoria, ciente e a própria ciência, encontra-se encerrado em numa unidade. Tal unidade, ao criar a multiplicidade dos existentes, o faz a partir de si mesma, como se auto-transbordasse para dentro de si, gerando, com isso, todas as formas da existência determinada. Fora da unidade do real, nada haveria. Dessa maneira, o processo de existenciação envolve - em sistemas de pensamento como o de Ibn'Arabī, que se valem desse modelo - diferentes instâncias decorrentes desse auto-transbordamento. A cada transbordar de si, uma nova esfera é criada, não para fora, mas para dentro. Esferas, que Ibn 'Arabī chama de estações.

O ser primeiro, por englobar tudo, seria a primeira esfera ou estação, depois, as demais esferas dela seguiriam, concentricamente, sempre para dentro de si, na direção do centro, ao redor do qual, a lua permanece como a décima esfera, a última das estações e, ainda, abaixo da qual, encontra-se a Terra, considerado o lugar mais baixo de todos os céus, bem no centro desse sistema.

Por isso, dizer que as sabedorias viajam desde a estação mais antiga é o mesmo que dizer que, desde sua essência, desdobram-se até assumirem formas cada vez mais particulares, formas cada vez mais determinadas. Desse modo, as sabedorias parecem já apresentar, nesse percurso, uma orientação na direção de uma determinação que as particulariza. Daí os títulos de cada um dos vinte e sete capítulos contidos no livro, em que

${ }^{91}$ Attie Filho, Miguel. Falsafa: a filosofia entre os árabes: uma herança esquecida. São Paulo: Palas Athena, 2002. pp. 200. 
cada um deles encontra-se em referência a uma sabedoria particular, designada pelo seu atributo.

Mantendo os olhos nos títulos dos capítulos do Fușusș, cabe pensar que o destino, ou um dos destinos, que a sabedoria encontra, no processo de emanação, é o coração daquele que melhor pode proferi-la utilizando-se da palavra, ou seja, o profeta. As sabedorias estariam, a princípio, todas reunidas na estação mais antiga da via - pensemos na via como sendo, inicialmente, o trajeto que percorrem as sabedorias - e, partindo dela, desceriam percorrendo possivelmente outras estações, de acordo com as esferas existentes, como já foi dito. Mas, seja qual for o trânsito das sabedorias, parecem estar sempre compreendidas na unidade da via, uma vez que a estação mais antiga engloba as demais. A qualidade de unidade evocada em relação às sabedorias em uma ordem transcendente faz frente às diversas comunidades históricas que, levando em conta os diferentes profetas que integram o Fuṣuss, encontram aqui suas referências, como a comunidade cristã, a comunidade judaica e a comunidade islâmica.

Assim, as sabedorias, das quais nos fala o autor, parecem valer para todas as comunidades, independente das diferenciações de credo, regra e forma que cada comunidade apresenta $^{92}$, indicando-se, com isso, algo de universal em relação às sabedorias. Sabedorias que se conservam transcendentes às formas históricas específicas assumidas por cada comunidade. Mas, ainda na primeira frase da introdução, o autor invoca o primeiro dos nomes ou atributos de Deus, na ordem da existenciação: o misericordioso ${ }^{93}$, para assim dedicar-lhe

\footnotetext{
${ }^{92}$ Sobre a unidade que rege as sabedorias em face às variações de credo, ver também Ibn 'Arabī, Le ivre des chatons des sagesses, op. cit., pp. 317 à 323 .

93 Para que se possa adentrar o significado desse nome ou atributo essencial, o "misericordioso", transcrevo aqui alguns trechos de Le dévoilement des effects du voyage, $O$ desvelamento dos efeitos de viagem, de Ibn 'Arabī, que podem contribuir para a compreensão de como o autor refere-se ao significado dos nomes ou palavras de acordo com as funções que desempenham na existenciação. Cada nome, sendo um atributo divino, possui uma função específica na metafísica desse autor, uma função de dar origem à manifestação dos existentes:

"Viagem senhorial desde a nuvem até o trono do estabelecimento onde assume posse o todo-misericordioso. Uma tradição conta que foi perguntado ao enviado de Deus - que Deus derrame sobre ele a graça e a paz! -: «Onde estava nosso senhor antes dele ter criado a criação? Ele respondeu: - Dentro de uma nuvem, mais baixo e mais abaixo do qual não havia mais ar.» Saiba que esta nuvem é a muralha da pessoa divina, imenso obstáculo que impede os seres de reaver a divindade absoluta e esta de reaver os seres, considerando do ponto de vista das definições essenciais. (...) Uma vez existenciada a esfera que abraça todos os seres e que a chamamos de o trono ou assento real santíssimo, necessariamente carecia de um rei. Como Deus queria a existenciação, fruto necessário da generosidade da existência divina, a qualidade de toda-misericórdia deveria reger esta separação entre o divino e o humano. O nome todo-misericordioso estabeleceu-se sobre o trono dentro da muralha da nuvem, como convém à qualidade divina de toda misericórdia, que é um aspecto da nuvem senhorial. Essa viagem da qualidade de toda-misericórdia desde a nuvem senhorial; até o seu estabelecimento sobre o trono, procede da generosidade, do mesmo modo que tudo aquilo que está deste lado do trono emana daquele que se estabeleceu sobre, quer dizer o nome o todo-misericordioso, cuja misericórdia contem toda coisa por necessidade essencial e dom gratuito. Como decorrência da viagem do nome o todo-misericordioso, viajam com ele todos os nomes ligados à criação: seus oficiais, curadores, emirs, como o fornecedor, o auxiliador, o vivificante, aquele que faz viver, aquele que faz morrer, o danoso, o benéfico e todos os nomes de atos em particular. Todo nome
} 
esse livro. Ao fazê-lo, o autor não só inicia uma ação, a ação de escrita propriamente dita do livro, como faz uma referência à origem do livro, à fonte ${ }^{94}$ de onde procede Kitāb fuṣuṣ alhikam. Por isso, do ponto de vista da existenciação, a estação mais antiga é presidida, regida pelo nome "o todo-misericordioso" e, portanto, as sabedorias viajariam desde a estação mais antiga, onde estariam reunidos todos os nomes correspondentes às sabedorias. Nesse sentido, vale notar ainda que Muhammad é referido pelo autor, nesse trecho, como a palavra mais eficaz, ou seja, a palavra que reúne em um só nome o poder de todas a sabedorias que encontraram, na pessoa do profeta Muhammad, sua máxima expressão ${ }^{95}$.

2. Em verdade, eu vi o enviado de Deus - que Deus derrame sobre ele sua graça unitiva e sua paz! - no decorrer de um sonho auspicioso que tive durante a última década de Muharram no ano de $627^{96}$, no recinto de Damasco. Ele segurava em suas mãos - sobre ele a graça e a paz! - um livro. Ele me disse: "Este é o Livro dos Engastes das Sabedorias; pegue-o e exprima-o aos homens, que eles possam disto tirar proveito!”. Eu respondi: “A escuta e a obediência são devidas a Deus, ao seu enviado e à aqueles entre nós que possuem o comando, conforme nos foi ordenado. ${ }^{97}$

3. Eu realizei o desejo, purifiquei a intenção, concentrei o esforço e a aspiração para a publicação desse livro dentro dos limites traçados para mim, pelo enviado de Deus sobre ele a graça e a paz! - sem nada acrescentar ou subtrair.

Eu pedi a Deus o altíssimo faça de mim, nessa circunstância como em todas as outras, um de seus servos sobre os quais o demônio não tenha poder; e de me conceder a graça especial, em tudo que escrevem meus dedos, que exprime minha língua e o que conserva meu coração, de uma inspiração transcendente e de uma insuflação espiritual no interior da alma através de uma confirmação preservadora; de tal maneira que eu seja um intérprete, não alguém que decide arbitrariamente; afim de que aqueles dentre as pessoas de Deus que são os mestres do coração realizem com certeza, uma vez que tenham acessado o conhecimento, que sendo proveniente da estação mais santa, puro de interesses individuais que poderiam introduzir o equívoco. ${ }^{98}$

Das mãos do enviado, Muhammad, o autor recebeu o presente livro, o que quer dizer a princípio que as sabedorias que o referido livro abarca, assim como o próprio livro que o

que expresse um ato fez a viagem com o todo-misericordioso, nenhum outro nome disto participa." Ibn "Arabī, Le dévoilement des effects du voyage. Trad. Denis Gril. Paris: Éditions de l'éclat, 2004, pp12, 13 e 14.

${ }^{94}$ A fonte aqui é justamente o nome ou o atributo "o todo misericordioso", o primeiro dos atributos divinos em relação à existência determinada.

95 De acordo com o que foi dito no capítulo dois desse estudo e poderá ser melhor compreendido no capítulo II, ítem 4.1 e na análise do vigésimo sétimo capítulo do $F u s ̦ u ̄ s$, no ítem 4.4 desse mesmo capítulo.

${ }^{96}$ No ano de 1249.

97 Ibn 'Arabī, Le livre des chatons des sagesses, op. cit., p. 27.

98 Ibidem., pp. 27 e 28. 
autor transmitiu, desceram da estação muḥammadiana. O que pode significar que nosso autor ascendeu à estação mais alta, a mais sagrada, tendo recebido a revelação de sua ciência, para fazer descê-la através da escrita e publicação desse livro, exprimindo-a aos homens para que possam ser beneficiados por essa ciência. Se assim for, como ele teria realizado tal ascese, seria o nosso autor um profeta como Muhammad ${ }^{99}$

4. Eu espero que Deus, tendo escutado minha prece que é um pedido, responda ao meu apelo. Transmito unicamente o que me foi transmitido; insiro nestas linhas unicamente o que me foi progressivamente revelado.

Não sou nem um profeta, nem um enviado, mas um herdeiro e um "cultivador" em vista da via futura. ${ }^{100}$

O autor não deixa de advertir que ele não é um profeta, nem um enviado, e sim um herdeiro em vista da via futura. Mas em que consistiria ser, assim, um herdeiro? Por hora, segundo o texto, pode-se afirmar que a condição de herdeiro lhe cabe por ter recebido e aceito, na qualidade de servo, o comando divino para transmitir o conhecimento proveniente da estação mais santa à todos aqueles que o procuram. E o faz purificando a intenção através de uma prece, deixando-a claramente expressa na introdução, a partir do terceiro parágrafo em diante $^{101}$.

${ }^{99}$ No sentido de lançar luz a questões como essas, vale atentar ao seguinte trecho do prefácio escrito por Ibn 'Arabī para seu livro Futuhat al-makkiyya, As iluminações mequenses:

"[O Profeta] a quem contemplei ao compor esse prefácio, no mundo das realidades [enquanto símiles] na presença da glória, por desvelamento ao coração diante da dignidade oculta. Assim o contemplei naquele mundo - Deus o bendiga e o salve! - como soberano inacessível às intenções, a salvo do olhar, ajudado e protegido. Todos os enviados estavam em filas frente a ele. Sua comunidade, - «que é a melhor comunidade» (3:110) o envolvia. Os anjos subjugantes se dispunham em círculo entorno do trono de sua estação e os anjos criados pelos atos de louvor em coro, por ordem de iguais, diante dele. (...) Nesse momento [o profeta] o soberano supremo, a aguada mais gostosa e doce, a luz mais desvelada e manifesta deu a volta e me viu atrás do selo [lugar onde me encontrava] por partilhar eu e ele da mesma condição. O soberano lhe disse: «Este é teu semelhante, teu filho e teu amigo íntimo. Instale diante de mim o púlpito das mesquitas de tamargueira». Logo [continuou dizendo o profeta] sinalizando para mim: «Suba nele, oh, Muhammad! E faça o elogio daquele que me enviou e a mim, pois em ti há [uma parte minha] que não pode privar-se de mim e que tem a soberania da sua pessoa. Portanto não se volte a mim, senão em sua totalidade, pois [tal coisa] deve retornar ao reencontro. Certamente não pertence ao mundo da miséria, já que depois que fui enviado ao mundo, não há nada de mim que não seja feliz, que não tenha sido louvado e acolhido com gratidão na assembleia suprema.» Então o selo instalou o púlpito nesta visão solene. Sobre o frontispício do púlpito estava escrito em luz muito brilhante: «Esta é a estação muhammadiana mais pura. Quem a ela ascende é seu herdeiro e o real (al-haqq) o envia para preservar e difundir o respeito à lei revelada (sari 'a)». Neste momento recebi os dons das sabedorias (hikam). Foi como se me tivera sido dada a 'totalidade das palavras'(jawami al-kalim). Dei graças a Deus - honrado e glorioso! - e ascendi e alcancei o lugar de onde [o profeta] - Deus o bendiga e o salve! - se encontrava e se estabeleceu. (...)". Ibn 'Arabī, Las iluminaciones de la Meca. Trad. Victor Pallejà de Bustinza. Ediciones Siruela. Madrid, 2005, pp. 39 e 40 .

${ }^{100}$ Ibn 'Arabī, Muhyi-D-Din, Le livre des chatons des sagesses (Fuṣūs al-hikam). Tradução, notas e comentário, Charles-André Gilis. Beirute, Libano: Ed. Al-Bouraq, 1997. p. 28.

${ }^{101}$ Segundo Ibn 'Arabī, a via até Deus é composta de quatro ramos, sendo um desses ramos os requerimentos. Esses requerimentos, por sua vez, são justamente o que está colocado no parágrafo três da introdução do Fușuss, a saber, o movimento dado pelo pensamento, a vontade, a resolução, a intensidade do espírito e a intenção. Cf. 
A leitura do trecho do prefácio do Futuhat, transcrito na nota anterior, fornece alguns dados a mais a respeito do lugar a partir do qual fala Ibn 'Arabī. Nosso autor, segundo seu próprio relato, ascendeu à estação mais alta, na qual o Profeta está estabelecido, partilhando com ele da mesma condição, no sentido de também acessar a mesma ciência, ainda que não pelos olhos do Profeta - o que considera um diferencial importante ${ }^{102}-$. E embora não sendo profeta, possui em seu próprio nome o nome de Muhammad. Abu Bakr Muhammad Ibn 'Ali ibn Muhammad al-Hātimī al-Ta'î ibn al- 'Arabī é herdeiro dessa estação porque a ela ascendeu e, como toda subida pressupõe a sua consequente descida, lá lhe é dado o comando de preservar e difundir aquilo que recebera, a saber, a ciência própria dessa estação $^{103}$, assim como os dons das sabedorias que ele relaciona com a totalidade dos nomes.

Ora, receber os dons das sabedorias equivale a receber, por dom, ${ }^{104}$ a capacidade de ver, de conhecer, por experiência, o que lhe é revelado, justamente por quem é a personificação dessa ciência, o profeta. Significa que, de fato, esse conhecimento lhe fora revelado e o saber a que nos referíamos, desde o início é esse, o saber da ciência mais elevada que tudo abarca.

Cada existente encontra sua realidade essencial nos nomes ${ }^{105}$, melhor, há sempre um nome subsistente em cada existente. Ora, não seria justamente essa a noção de

Ibn 'Arabī, Las iluminaciones de la Meca. Trad. Victor Pallejà de Bustinza. Madrid: Ediciones Siruela, 2005, p. 65.

${ }^{102}$ Cf. A seguinte passagem: “(...) Sobre o degrau em que eu me encontrava foi estendida a manga de uma túnica branca. Me coloquei sobre ela para não tocar diretamente o lugar que seus pés - deus o bendiga e o salve! haviam tocado, por respeito a sua incomparabilidade e honra, advertido e conhecedor de que a estação desde a qual [o profeta] contemplou seu senhor, seus herdeiros não a contemplam de nenhuma outra maneira que desde seus próprios trajes. Se isso não tivesse sido assim, não teríamos sido dado a conhecer o que vimos, nem conhecido o que conhecemos." Ibn "Arabī, Las iluminaciones de la Meca. Trad. e notas: Victor Pallejà de Bustinza. Madrid: Ediciones Siruela, 2005, p. 40

103 Ciência que abarca todas as outras ciências, tema do cap. 27.

104 Qual vem a ser a relação dos dons com as sabedorias será tema do cap. 2.

105 "Prefácio ao livro: A investidura de Ibn 'Arabī como selo da santidade muhammadiana.

[41] Em nome de deus, o misericordioso, o clemente.

O louvor é de Deus, que deu existência às coisas desde o nada, fazendo este inexistente ao erigir sua existência através da orientação de suas palavras, a fím de que por este meio realizássemos o segredo da sua origem temporal e eterno, em relação a sua eternidade, e compreendêssemos, ao verificar isso, o que ele nos ensinou a respeito da veracidade de seu pé - vale observar que qadam, pé, e qidam, eternidade ou pré-existência, possuem a mesma raiz -. Mostrou-se - exaltado seja! - e manifestou e fez manifestar, sem deixar nada oculto; mesmo assim, foi ocultado e fez ocultar. O nome divino 'o primeiro' estabeleceu a existência específica (wuyud 'ayn) do servo, que já havia sido estabelecida. O nome divino 'o último' estabeleceu o decreto imutável da extinção e da perda final [de todos os seres] que havia sido estabelecida com anterioridade. Pois se não fosse pela distinção entre o atual e o que se faz presente, o ignorado e o conhecido, não se conheceria o significado de seus nomes [42] 'o primeiro' e 'o último', nem 'o oculto' e 'o manifesto'. Certamente, seus belos nomes encontram-se desse modo em seu máximo esplendor. No entanto, entre eles há diferenças segundo suas [respectivas] moradas. Isso resulta evidente quando se toma intermediários para a ocorrência de eventos. Pois não é servo do 'paciente' o servo do 'generoso', nem servo do 'magnânimo' o servo do 'agradecido'. Cada servo tem um nome que é seu senhor. Ele é um corpo cujo coração é esse nome." Ibn 'Arabī, Las iluminaciones de la Meca. Trad. e notas: Victor Pallejà de Bustinza. Madrid: Ediciones Siruela, 2005, p. 35 e 36. 
substância em Aristóteles? Os nomes, do ponto de vista do real (al'haqq) seriam seus atributos. Os mesmos nomes, do ponto de vista da multiplicidade dos existentes, seriam as próprias substâncias. Desse modo, os atributos do real conservar-se-iam enquanto ciência, na estação mais elevada, na estação muhammadiana, e apenas se tornam atualizados ou manifestos a partir do efeito de seus nomes. Apenas a qualidade do nome viaja, por processão $^{106}$, mas o nome, ele mesmo, enquanto substância, permanece sempre em sua estação.

5. O que vem assim de Deus, escute-o e para deus volte-se! Quando você escutar o que lhe trago, guarde-o atentamente! Em seguida, tenha uma compreensão distinta de um propósito sumário; opere a síntese! Em seguida, faça beneficiários aqueles que o procuram; não os recuse! Tal é a misericórdia que se estendeu até você. Ao seu redor, derrame-a!

6. É de Deus que eu espero ser dentre aqueles que beneficiaram a confirmação divina, são confirmados e podem, por sua vez, confirmar aos outros; daqueles que foram sujeitados à lei muhammadiana puríssima, se assim foram sujeitados de seu pleno e assim sujeitaram outros. Possamos nós sermos reunidos em seu grupo da mesma maneira que pertencemos a sua comunidade!

7. A primeira coisa que o rei transmitiu ao servo, $\mathrm{e}^{107} \cdot{ }^{108}$

A relação de senhorio é uma constante referência nos escritos de Ibn 'Arabī, retoma sempre a lembrança de que um servo nunca existe sozinho, se há um servo é porque há também o seu senhor. Esse é um modelo de relação cuja compreensão deve ser aplicada à toda realidade existente, uma vez que o múltiplo apenas existe como forma de manifestação do uno.

Que nunca se perca de vista que, para esse autor, há apenas uma única realidade existente, apenas o uno, apenas o real, não há outro existente ${ }^{109}$. Compreender isso é operar a síntese sugerida pelo autor no parágrafo quinto da introdução, pois um homem só pode compreender sua realidade essencial, se compreender que a criatura não é diferente do

\footnotetext{
${ }^{106}$ No sentido de proceder, fluir, emanar.

${ }^{107} \mathrm{O}$ texto da introdução acaba exatamente aqui, evidenciando que se completa, em sua continuidade, com o título do primeiro capítulo.

${ }^{108}$ Ibn 'Arabī, Muhyi-D-Din, Le livre des chatons des sagesses (Fuṣūṣ al-hikam). Tradução, notas e comentário, Charles-André Gilis Beirute, Libano: Ed. Al-Bouraq, 1997. pp. 27,28 e 29.

${ }^{109}$ Sobre essa perspectiva que orienta marcadamente a concepção de Ibn 'Arabī, vale a leitura do seguinte trecho escrito por ele: “(...) Se dirige a palavra ao seu seu servo, ele é o ouvido e aquele que escuta, se o servo cumpre o que ele ordenou que seja feito, ele é então o obedecido e o obediente. Quando essa verdade me preencheu de perplexidade, recitei acerca da condição própria da criatura: O senhor é uma realidade e o servo é uma realidade. Se apenas soubesse qual dos dois é aquele que se submete às obrigações legais! Se tu dizes: o servo, esse está morto. Ou se dizes: o Senhor, de onde [procede] a obrigação legal? Ele - exaltado seja! - obedece a si mesmo quando quer, através da sua criação, e divide a si mesmo com equidade, segundo o que determina necessariamente sua própria realidade. Assim, não há senão aparições vazias, completamente instáveis, repetindo-se em eco. Segredo ao qual fizemos alusão para aqueles que são guiados." Ibn "Arabī, Las iluminaciones de la Meca. Trad. Victor Pallejà de Bustinza. Madrid: Ediciones Siruela, 2005, p. 37.
} 
criador, estando a realidade dos múltiplos "subjugada" por aquilo que ela é essencialmente, isto é, pelo real, ou o que é o mesmo, pelo uno.

É com esse entendimento que se deve considerar a qualidade senhorial aplicada à nuvem ${ }^{110}$, no sentido de estação, e equivalente à primeira delas, tal como as esferas dos modelos cosmológicos absorvidos por sistemas metafísicos conforme foi dito anteriormente, no início desse capítulo.

Recomenda ainda ao leitor que receba e guarde atentamente o conhecimento apresentado nesse livro, tendo operado a síntese ao buscar compreendê-lo essencialmente, e procedendo de forma a tê-lo consigo para disponibilizá-lo a quem manifestar interesse, mantendo assim disponível o conhecimento que lhe fora disponibilizado.

${ }^{110}$ Cf. nota 93 . 


\section{Espelho do real e a sabedoria de Adão}

O primeiro capítulo do Kitāb fușūṣ al-hikam configura-se como se fosse uma matriz das relações conceituais fundamentais a estruturar a obra como um todo. Nele, o autor apresenta uma reflexão sobre o significado e os aspectos da sabedoria de Adão, o primeiro dos profetas.

No entanto, antes de explorar o que é próprio do nome destinado a Adão, Ibn 'Arabī dedica-se a apresentar as condições de possibilidade da manifestação da sabedoria divina, através do ato de vontade do real de ver a si mesmo.

1. Uma vez que o real ${ }^{111}(a l-h a q q)$ quis - glória a sua transcendência! -, em seus nomes excelentes (al-asma al-husnā) cuja multidão é inumerável, ver suas determinações ${ }^{112}\left(a^{\prime} y \bar{a} n\right)$ - se você quiser, você pode dizer "ver sua determinação"( 'ayn)- em um ser total (kawn) que encerra a [ordem] $]^{113}$ toda (al$a m r)^{114}$, um ser que possui o atributo da existência (al-wujūd), a fim de nele tornar manifesto seu próprio segredo (sirr) a si-mesmo... ${ }^{115}$.

Nesse parágrafo inicial, Ibn 'Arabī apresenta a vontade divina como um princípio ordenador, uma vontade - vontade criadora - que não é intransitiva ${ }^{116}$ e se realiza pela visão, cuja efetivação ocorre ao ver manifesto o segredo, aquilo que antes permanecia oculto.

O real $(a l-h a q q)$ quis ver suas determinações primeiras, determinações presentes nos nomes divinos em um ser que compreendesse a totalidade desses nomes. Esse ser reuniria, portanto, em si, toda a multidão infinita dos nomes, o que equivale a dizer, toda a ordem ou a realidade considerada em sua totalidade.

Ao ver esse ser, dotado de existência e capaz de abrigar todos os nomes, o real pôde ver sua própria determinação, ou, dito de outro modo, o real pôde ver suas determinações ao ver todos os seus nomes em um ser existente, com a finalidade de tornar manifesto aquilo que, de outro modo, permaneceria oculto, tal como um segredo ${ }^{117}$.

\footnotetext{
${ }^{111} \mathrm{Na}$ tradução francesa de Gilis houve preferência pela palavra "Deus", ainda que, em nota, faça referência a "al-haqq", o real, termo utilizado por Ibn "Arabī, por isso a escolha do termo "o real" aqui.

${ }^{112}$ Em tradução direta do árabe verifica-se que Ibn "Arabī utilizou o termo "determinação" e não "essência" tal como foi traduzido por Gilis.

${ }_{113}$ Diferentemente da tradução adotada, escolheu-se utilizar para esse termo al-amr, ordem e não realidade.

114 Termo que designa a realidade manifesta e está de acordo com kawn aqui traduzido por "ser".

${ }^{115} \mathrm{Ibn}$ 'Arabī, Le livre des chatons des sagesses, op. cit., p. 43.

${ }^{116}$ No sentido de que se trata de uma vontade que, para se realizar, exige algo específico, a saber, a visão de si mesmo em outra coisa.

117 O significado implicado nessa passagem é melhor explorada no capítulo quatro, $O$ engaste de uma sabedoria santíssima em um verbo de Enoque. Nesse capítulo, há um trecho que auxilia no que não pode ser ainda esclarecido no primeiro parágrafo do primeiro capítulo, traduzido acima no corpo do texto. A saber, antes de manifestar o ser que compreende a realidade total por meio da totalidade dos nomes do real, o que permanecia
} 
A visão que uma coisa tem dela mesma, por ela mesma, não é comparável àquela que ela tem dela mesma em uma outra que lhe serve de espelho, uma vez que sua visão se opera, então, na forma que lhe confere o suporte do seu olhar. Sem a existência desse suporte, ela não poderia nem se manifestar nem aparecer para ela mesma ${ }^{118}$.

O que parece ser distinto aqui é a visão, isto é, a visão do mesmo por si mesmo é distinta da visão do mesmo de si em um outro cuja forma seja existente. A visão de si é dada por essa forma, depende dessa forma, e é de acordo com a forma. Sem tal forma, não haveria visão de si mesmo em um outro.

O real existenciou o mundo em sua totalidade como um esboço harmonioso, mas desprovido de espírito; semelhante a um espelho não polido. É próprio da natureza da ordem divina jamais dispor harmoniosamente um receptáculo se isso não for em vista de acolher um espírito divino, o que é evocado pela ideia da insuflação; e isso nada mais é que o resultado da pré-disposição, por parte de tal forma, para a recepção do fluxo magnificente, perpétuo, aquele que não cessa nem cessará. Com efeito, não subsiste senão um único receptáculo, e não existe receptáculo que não proceda do fluxo sagrado, a ordem inteira dele faz parte, desde seu começo até seu fim: e a ele retorna a ordem inteira ${ }^{119}$, assim como tudo dele procede em sua origem - ... a ordem implicava a clarificação do espelho do mundo e Adão é a essência da pureza transparente desse espelho, assim como o espírito dessa forma.$-{ }^{120}$

O processo de existenciação aqui descrito sugere que se distinga alguns elementos que dele participam. Sabe-se, até esse ponto, que o real, em um ato de vontade de ver a si mesmo por meio de um outro, cria, conferindo existência a uma determinada forma que é total, reunindo nela todos os seus nomes, isto é, seus atributos.

No entanto, não bastaria haver a forma existente - o que seria o mesmo que estar diante de um espelho não polido, insuficiente para gerar qualquer reflexo ou imagem de si para si. Seria preciso o acréscimo daquilo que vivificasse a forma, ativando-a em sua

como um segredo, permanecia também oculto para o próprio real? Porque um segredo pode ficar guardado por alguém que o conhece e apenas não o manifesta. Vamos ao trecho do quarto capítulo: "(...) Al-Kharrāz - que Deus lhe tenha misericórdia! -, que fora uma das faces de deus e uma de suas línguas, disse ao falar de si mesmo, que 'Deus não pode ser conhecido senão pela reunião de seus contrários...' que lhe são aplicados uma vez que... "ele é o primeiro e o último, o exterior e o interior" (Cor., 57, 3.): ele é a essência daquilo que é aparente e a essência daquilo que permanece no interior do seu estado de manifestação; não há qualquer outra pessoa além dele para vê-lo e ninguém no interior de quem pudesse permanecer dentro; é ele que aparece para si mesmo e que é velado a si mesmo; é ele que tem como nome Abu Sa'id al-Kharrāz; e o nome dos outros "seres produzidos" são igualmente os seus. (...) O ser é único apesar de suas diversas atribuições. É impossível ignorar uma situação como essa, pois todo homem possui a ciência por ele mesmo e ele é a imagem de Deus." Ibn 'Arabī, Le livre des chatons des sagesses, op. cit., pp. 153 e 154.)

${ }^{118} \mathrm{Ibn}$ 'Arabī, Le livre des chatons des sagesses, op. cit., p. 43.

${ }^{119}$ Corão, $11,123$.

${ }^{120} \mathrm{Ibn}$ 'Arabī, Le livre des chatons des sagesses, op. cit., pp. 44 e 45. 
função, atualizando-a - o equivalente a polir a superfície do espelho. Trata-se, portanto, do fluxo $^{121}$ que a forma necessita receber, para tornar-se não só um receptáculo do fluxo do real, mas também um receptáculo para o real que continua fluindo através dela. ${ }^{122}$

Ocorre que, sendo um ato de vontade de ver específica do real, ele, ao criar a forma para ser o suporte desse reflexo, cria uma forma já pré-disposta a receber o que ele próprio irá nela projetar, de modo que, quando a forma se manifesta, apresenta-se completamente apta a servir ao propósito para o qual fora criada.

Se todo receptáculo procede do fluxo da essência do real, se todo receptáculo é a atualização, em forma, do que permanecia em potência no real enquanto não-manifesto, então, todos os receptáculos são diferentes expressões do mesmo, cada múltiplo é expressão do si mesmo e, por isso, manifesta a essência do uno.

Não há, assim, qualquer receptáculo, na ordem dos múltiplos, que não tenha sido pré-concebido pela essência fluida do real e, consequentemente, que não tenha sido previamente abarcado pelo receptáculo da forma total.

O que vem a ser Adão, a partir do que começa a se configurar no início desse capítulo, parece coincidir com a função exercida pela forma total, receptáculo para o que Ibn 'Arab̄̄ vem apresentar como sendo a sabedoria, a qual necessita de uma forma capaz de abrigar todos os nomes para se manifestar.

Vale ressaltar que a forma total, sendo representada por Adão, confere à sabedoria uma condição de caráter profético. Ou seja, a sabedoria, na sua origem e naquilo que possui de mais essencial, assume a forma profética. Desse modo, a profecia exerce para a sabedoria, cujo destino encontra-se implicado na revelação, uma definição.

Se, nesse aspecto, é importante lembrar que o autor considera Adão um profeta, é importante também compreender em que sentido ele o faz. Antes de mais nada, Adão representa, na metafísica do autor, a própria condição de possibilidade da essência do real tornar-se manifesta, tornar-se revelada, e, portanto, conhecida. Esse é o significado da imagem utilizada pelo autor do espelho polido que reflete o real.

\footnotetext{
121 A palavra no texto árabe é fayd : transbordar.

122 Se fizéssemos uma comparação do real com o som, teríamos o seguinte: o som propagando-se no espaço infinito, sem forma, não seria para nós audível. Seria preciso a existência de uma forma a habitar esse espaço para que, a partir da forma, o som pudesse reverberar em algum corpo - o que seria oferecido pela resistência da matéria enformada - e se tornar audível. Desse modo, o ouvido humano seria capaz de reconhecer um som e o som reconhecido por meio de uma forma não seria o mesmo, caso a mesma vibração incidisse em uma forma diferente da primeira. O som, portanto, é sempre segundo uma determinada forma. Assim, a vibração emanada, propagando-se pelo espaço, alcançaria alguma forma e dela continuaria a propagar-se, mas agora vibrando a partir dessa forma, isto é, tendo adquirido configurações outras conferidas pela especificidade da forma.
} 
A unidade do real para o real, por estar implicada em um fluxo permanente, ao encontrar sua forma-receptáculo, primeira determinação, encontra nela o nome de todos os seus atributos, por meio dos quais se particulariza, podendo ver-se refletida em cada um de seus nomes. Ao ser assim projetada, ao encontro da multiplicidade de seus nomes, a sabedoria obtém, mediante o nome de cada profeta, o modo, por excelência, para suas manifestações.

Assim, temos que Adão corresponde à forma-espelho, superfície perfeitamente polida, capaz de refletir a sabedoria decorrente da ciência mais elevada. Essa é a sabedoria que irá apresentar-se como muhammadiana - tratada no último capítulo. O mundo inteiro principia por meio da multidão dos nomes do real que estão em Adão.

Por tratar-se da unidade do real, cada manifestação desse uno, está engastada e é engaste para outra manifestação, naquilo que é exigido pela unidade. É importante notar, pois, o modo como cada existente apresenta-se já implicado, desde sua origem, em outro existente. Com isso, é possível começar a vislumbrar a dinâmica que envolve os capítulos de Fuṣūṣ. Estamos longe de uma construção linear, meramente explicativa, como já dissemos. As peças-chave desse complexo sistema de pensamento não estão colocadas lado a lado e, muitas vezes, o que parece ser um único conceito torna-se um conjunto deles; e cada um, se visto em uma dada perspectiva, apresenta uma coloração, se transferida a perspectiva, assume outra coloração. Por isso, o modo de gerar conceitos e suas respectivas significações, parece acompanhar esse modelo de implicações. É preciso procurar pela perspectiva que está sendo adotada, por exemplo, se o autor está afirmando algo com relação à unidade ou à multiplicidade.

Dentro dessa perspectiva do múltiplo como fluido da unidade do real, Ibn 'Arabī passa a discriminar algumas das formas particulares de tal manifestação. Vamos a essa passagem:

Os anjos seriam algumas das faculdades dessa forma que é, por sua vez, a forma do universo, a qual algumas pessoas designam, na linguagem que lhes é própria, como o grande homem ${ }^{123}$. Os anjos são para aquele o que as faculdades espirituais e sensíveis são na constituição do homem. Cada uma delas, é ocultada por si mesma e não vê nada além do que a excelência de sua própria essência. Cada uma pretende ser digna dos postos mais elevados, dos graus mais sublimes próximos de Deus, de modo que ela participa da qualidade divina sintética pelos diferentes aspectos que ela rege: aquele que se volta ao real, aquele que se volta à realidade das realidades e - na

123 O “grande homem”, como está no texto árabe, e não "macrocosmos” como consta da tradução francesa. 
condição que comporta essas qualificações - aquele que se volta à natureza total que inclui o conjunto dos receptáculos do universo, do seu topo ao seu mais profundo. ${ }^{124}$ Importa ressaltar aqui que aquele que busca conhecer a realidade total - isto é, o grande homem -, aquele que busca conhecer a verdade, ao se utilizar das faculdades humanas, sejam as espirituais, sejam as sensíveis, tem suas faculdades regidas por esses anjos.

Tudo isso, o intelecto não pode compreender pela via da especulação racional. Uma compreensão desse tipo não pode ser operada senão por meio de uma intuição divina que permite conhecer a origem das formas do universo, que são os receptáculos dos espíritos que os regem. ${ }^{125}$

Ibn' Arabī termina o primeiro parágrafo do primeiro capítulo indicando ao leitor o modo de compreensão mais apropriado a ser empregado na leitura de seus textos, a saber, a intuição divina. Com isso o autor também parece eleger o leitor que estaria mais apto a compreendêlo. ${ }^{126}$

Esse que acabamos de mencionar porta os nomes de "homem" e de "califa". "Homem", pela universalidade da sua constituição que inclui todas as verdades primeiras. Ele é para o real o que a pupila é para o olho, que é o órgão do olhar. É por que essa faculdade é designada como sendo a vista, que a pupila porta - igualmente o nome de "homem": por ele, o real olha as criaturas e lhes concede misericórdia. Ele é o homem novo e eterno, o gerado sem começo nem fim, o nome que separa e une.

O mundo está acabado por seu ser que dele faz parte do modo como o engaste faz parte do anel. Ele é a impressão e o signo sobre o selo que o rei coloca sobre seus tesouros. O altíssimo o chamou 'califa' por essa razão. Ele preserva através dele suas criaturas, como o selo preserva os tesouros. Uma vez que o selo do rei permanece colocado, ninguém terá a audácia de abrir seus cofres sem sua permissão. Ele o predispôs à guarda do reino. $\mathrm{O}$ mundo não cessa de ser preservado enquanto o homem perfeito nele permanece. ${ }^{127}$

\footnotetext{
${ }^{124} \mathrm{Ibn}$ 'Arabī, Le livre des chatons des sagesses, op. cit., pp. 45 e 46.

${ }^{125}$ Ibidem, p. 46.

${ }^{126}$ Sobre esse aspecto, ver a seguinte passagem: “(...) aquele que é dotado de capacidade para receber os dons espirituais, que busca um desenvolvimento em ciência e que é receptivo aos atos da generosidade divina através da via dos segredos da existência. Pois, para quem é dotado, se persiste no retiro intelectual e na invocação divina, esvazia o receptáculo do coração de pensamentos discursivos e se senta diante da porta do seu senhor como pobre que nada tem, então Deus - exaltado seja! - o concederá e dará parte da sua ciência, dos segredos divinos e do senhorio que Deus encomendou ao seu servidor Jidr.(...) Assim, quem é dono de aspiração espiritual durante o retiro com Deus poderá alcançar, por meio dele, conhecimentos que estão ocultos a todo teólogo dogmático (mutakallim) sobre a terra e, a todo mestre da reflexão - filósofo especulativo - e da prova que careça de tal estado espiritual, que certamente está mais adiante da indagação intelectual." Ibn 'Arabī, Las iluminaciones de la Meca. Trad. e notas: Victor Pallejà de Bustinza. Madrid: Ediciones Siruela, 2005, p. 55 e 56.

${ }^{127} \mathrm{Ibn}$ 'Arabī, Le livre des chatons des sagesses, op. cit., p. 47.
} 
Cada homem, na multiplicidade dos existentes, foi gerado a partir de Adão, cuja constituição perfeita encontra-se na origem de todo homem. E é justamente o conhecimento dessa forma perfeita - que abarca a ciência de todos os nomes divinos, sua própria origem essencial - que os homens devem buscar conhecer.

Sem Adão, o real não conseguiria ver a si mesmo em outro. Por meio de Adão é que o real pode ver a si - a própria unidade - em cada particular, reconhecendo-o como aquilo que procede de si mesmo. Essa é a razão da comparação, na imagem a que o autor refere-se, entre Adão e a pupila no olho do real, similar à anterior imagem do espelho que recebeu o polimento.

Sendo o "todo-misericordioso" o nome portado por Adão e, sendo esse o nome que contem todos os atributos divinos, através da constituição de Adão "o real olha todas as criaturas e lhes concede misericórdia" 128 . Ou seja, reconhece a si mesmo ao olhar para todas as criaturas, que, por sua vez, encontram sua causa na misericórdia, uma vez que todas procedem do nome "todo-misericordioso".

Adão, forma embebida da essência fluida e toda transbordante, por meio da qual o universo encontra-se atualizado e manifesto, recebe o nome de homem como já foi visto, o homem perfeito - tema que será melhor desenvolvido no capítulo quatro do Fușūṣ̣, no qual o autor esclarece sobre as razões pelas quais Adão porta o nome "califa".

Essa é uma das coisas mais estranhas: o homem é o mais elevado dos seres existenciados, quero dizer o homem perfeito; e portanto a elevação não lhe é atribuída senão em relação ao lugar ou em relação ao posto, quer dizer, ao grau; ela não pertence à sua essência: ele é "elevado", seja pela elevação do lugar, seja pela do posto, uma vez que é a esses dois que a elevação pertence. A elevação do lugar é, por exemplo, “o todo-misericordioso está sentado em majestade sobre o trono"(Cor., 20,5) uma vez que esse é o mais elevado dos céus; a elevação do posto, é "Todas as coisas perecem salvo sua face" (Cor., 28,88) e "A ele pertence a ordem inteiramente" (Cor., 11, 123) (...). Quando Deus, o altíssimo, diz: "E nós o exaltamos em um lugar elevado", ele faz da elevação um atributo do lugar; "E como teu senhor disse aos anjos: em verdade, eu vou estabelecer sobre a Terra um califa, trata-se da elevação do posto. (...) Nesse caso, ele atribuiu a elevação aos anjos. Portanto, se ela thes pertencesse por serem anjos, ela lhes concerniria indistintamente. Como não é o caso para alguns, ainda que estejam associados aos outros na mesma definição, podemos concluir que essa elevação é aquela do posto próximo a Deus. Da mesma forma é o

${ }^{128}$ Ibidem, p.47. 
que se dá para os califas: se a elevação deles pelo califado lhes pertencesse de modo essencial, todo homem seria califa. Como esse não é o caso, sabemos que essa elevação é a do posto. ${ }^{129}$

A forma completa-se, atualiza-se, no processo de constituição de si, com a presença daquilo a que está apta e designada a receber. O espírito, ou a essência, toma parte na forma, nela vem habitar, tal como a pedra preciosa encontra seu encaixe perfeito no engaste do anel. A imagem que relaciona o homem perfeito à pupila do real, sintetiza muito bem o significado de Adão tanto para o real quanto para o homem. Se considerarmos a mesma essência emanando a si mesma e, assim, criando a multiplicidade dos existentes, haveria alguma continuidade entre o criador e criatura, garantida por um intermediário, Adão.

Tanto o real quanto o homem voltar-se-iam na direção de tal ser intermediário, seja por meio do processo existencial, no caso do real, seja pelo processo gnosiológico, no caso do homem. Uma vez que o real, ao existenciar o mundo, o faz na direção de Adão, o mundo é posterior a ele, é seu efeito, assim como os homens e toda a multiplicidade dos existentes. $\mathrm{O}$ homem que deseja conhecer a verdade, a realidade de sua própria essência, deve prosseguir no caminho inverso, partindo da realidade dos existenciados, procurando a essência através de seus nomes. Dessa maneira, o mundo permanece todo inserido no grande homem, deriva da forma perfeita originária do real, forma-receptáculo da sabedoria muhammadiana ou do nome todo-misericordioso e, assim, prossegue a estrutura do engaste que se apresenta essencial e fundante do sistema akbariano já existente entre o real e Adão e, agora, entre Adão e o mundo, assim estendendo-se infinitamente.

Você não o vê? Quando ele se for, quando o selo se quebrar sobre o cofre desse mundo, o que o real nele guardava não permanecerá mais nele e dele sairá; cada parte voltará a encontrar aquela que lhe corresponde, a ordem manifesta transportar-se-á na vida futura. O califa será então o selo dos tesouros dos existentes dessa vida que virá, seu selo para sempre. ${ }^{130}$

Dito de outro modo, essa conformidade da forma em relação à sua essência é o que garante a salvaguarda do mundo. A forma, por ser assim, enquanto estiver servindo ao que fora designada, estará sempre assegurada. Mas se a forma se quebrar, se por algum motivo deixar de ser o que é, aquilo que a essência do real fazia fluir por meio dela, será interrompido e desviado. A forma, que assim tornar-se desprovida do fluxo, ficará vazia, deixará de fazer as vezes de um espelho polido, ficando impossibilitada de abarcar os nomes que, originalmente, lhe foram designados.

\footnotetext{
${ }^{129}$ Ibidem, pp. 150 e 151.

${ }^{130}$ Ibidem, pp. 47 e 48.
} 
O califa nunca deixará de ser o califa e de atuar enquanto tal na sua perfeição dentro da ordem porque a própria ordem exige isso, ainda que não seja mais nesse mundo.

3. O conjunto dos nomes ligados às formas divinas é manifesto na condição humana que engloba e une através desse ser adâmico. Graças a ele, o real o fez valer na sua argumentação com os anjos. Tome cuidado, pois é você que ele adverte através do exemplo de outro alguém! Considere a origem da sua derrota: os anjos perderam de vista a constituição privilegiada desse califa, assim como a adoração essencial requerida pela dignidade divina; uma vez que ninguém pode conhecer do real senão aquilo que ele confere à sua própria essência, e os anjos não possuem a qualidade sintética de Adão. Eles perderam de vista que os nomes divinos através dos quais eles celebram a transcendência e a santidade divina lhe são particulares; ignorando que o real possui nomes cuja ciência não lhes é dada, de modo que não podem celebrar sua transcendência e sua santidade da mesma maneira que Adão. Dominados pelas limitações que mencionamos, sob as influências de seu estado e de sua condição, disseram: "Você irá estabelecer nesse lugar alguém que irá semear a corrupção?"; visando por isso unicamente a oposição, implicada pela natureza de Adão, que foram eles mesmos que manifestaram! Sua acusação contra Adão aplica-se à sua própria atitude a respeito do real! Foi sua própria natureza que lhes rendeu tal atitude, e eles não tinham consciência disso! Se tivessem conhecido a si mesmos, eles saberiam; e se soubessem, teriam sido preservados. Eles somaram a pretensão à difamação ao evocarem sua própria maneira de celebrar a transcendência e a santidade. Uma vez que havia na constituição de Adão nomes divinos deles ignorados, não poderiam com ele rivalizar nessa celebração.

$\mathrm{O}$ real nos recitou isso a fim de que nos detenhamos e que aprendamos o senso das conveniências para com ele e que, uma vez cientes de nossa condição, não emitamos nenhuma pretensão a respeito daquilo que temos realizado e dominado. Assim, como poderíamos nos permitir enunciar uma pretensão que se estendesse a aqueles cujo estado e a ciência não possuímos, sem, com isso, cobrirmo-nos de ridículo? Esse conhecimento é daqueles através dos quais o real educa seus servos que possuem o senso de conveniência, os homens de confiança, os califas. ${ }^{131}$

Nessa passagem, Ibn 'Arabī, novamente, refere-se ao posto ocupado por Adão, assumido no interior da condição humana, posto esse que não pode ser compartilhado pelos anjos, cuja condição difere da dos humanos. Essa parece ser uma questão fácil de ser ignorada pois se pode pensar que os anjos possuem uma constituição mais perfeita que os homens, no sentido de estarem mais próximos de Deus, o que é correto. Mas quem considera tal questão, conhece

${ }^{131}$ Ibidem, pp. 48 e 49. 
mais perfeitamente a condição adâmica, isto é, a origem da forma humana que, como já foi dito, foi elevada a tal posto, por isso há que se considerar as coisas desse modo.

Além disso, a ciência dos segredos requer a revelação - não se pode conhecê-la somente pela razão -, a revelação depende dos dons, os dons dependem, entre outras coisas, da forma condizente de se adorar o real, de louvá-lo, de acordo com seus nomes, de modo que ao ignorar a exata condição de Adão, ou a totalidade de seus nomes, também ignora-se tanto os limites, como a forma correta de aquisição do conhecimento. Por isso os anjos incorreram em tal erro, ao negligenciarem sua incompletude face à condição humana - possuidora de todos os nomes divinos.

Os nomes divinos - determinantes particulares de cada ser -, através dos quais os anjos celebram a transcendência e a santidade divina, são aqueles próprios da condição angélica. Isso significa dizer que, se os anjos tentarem louvar a Deus com nomes que pertencem à condição própria de outro ser, como a dos humanos, ferirão a ordem divina, incorrendo contra a verdade e sua plena realização, pois justamente atuam segundo sua impossibilidade, negando o louvor necessário à dignidade divina.

4. Isso dito, voltemos à sabedoria. Saiba que as ideias universais são desprovidas de realidade própria; entretanto, elas podem, sem qualquer dúvida, serem concebidas e conhecidas no mental. Elas permanecem sempre interiores em relação à existência determinada, exercendo totalmente seu poder e seu efeito sobre tudo que dela faz parte; ou ainda, elas não são nada de outro, quero dizer: diferente das qualificações dessa existência. Elas não cessam de ser inteligíveis por elas mesmas: elas são "exteriores" do ponto de vista das determinações existenciais e "interiores" sob o aspecto da sua inteligibilidade. Toda existência determinada depende das ideias universais que não podem, nem ser separadas do intelecto, nem cessar de ser inteligíveis pelo fato da sua atualização em modo determinado; pouco importa que essa qualificação seja submetida ou não à condição temporal, uma vez que, nos dois casos, sua relação com a ideia universal é a mesma. Por outro lado, a ideia universal é regida pelas qualificações da existência determinada, segundo o que requerem as realidades primeiras correspondentes. Por exemplo, a ciência na sua relação com o sábio ou a vida na sua relação com o vivente. A vida é uma realidade primeira inteligível e a ciência é uma outra, distinta da vida tal como a vida é distinta dela. Ora, dizemos do real que ele possui ciência e vida, e que ele é o vivente, o sábio, e dizemos exatamente a mesma coisa do anjo e do homem. As noções de ciência e de vida permanecem idênticas - em todos os casos -, do mesmo modo que a relação da primeira com o sábio e da segunda com o vivente. Não obstante, nós dizemos da 
ciência do real que ela é eterna e da ciência do homem que ela é efêmera. Considere esse poder de atribuição sobre a realidade inteligível! Considere essa conexão entre os princípios inteligíveis e as qualificações da existência determinada: de um lado, a ciência rege aquele ao qual ela se dirige e o torna um sábio; por outro, este rege a ciência tornando-a efêmera, no caso de um ser efêmero, e eterna, no caso de um ser eterno. Cada um é então, ao mesmo tempo, "regente" e "regido". ${ }^{132}$

Como se pode observar, nessa passagem o autor examina a natureza das ideias universais, seu significado em relação à existência determinada, o modo como se pode afirmar que a existência determinada qualifica as ideias universais e a condição de inteligibilidade inerente aos universais. É possível afirmar que, para Ibn 'Arabī, as ideias universais, embora não possuam realidade própria - não subsistem por si mesmas, uma vez que suas existências decorrem do real, único existente por si -, são o que qualifica a existência determinada. Ou, o que é o mesmo, a existência determinada se dá segundo as ideias universais.

As ideias universais são inteligíveis por si mesmas e inseparáveis do intelecto. O fato de se atualizarem por meio da existência determinada, não as torna menos inteligíveis. As ideias universais permanecem interiores em relação à existência determinada. Em relação à multiplicidade dos seres, o primeiro a ser conhecido é a existência determinada, e, por meio dela, a intelecção dos universais. Conservando a distinção entre ambos, é como se a existência determinada fosse a face externa das ideias universais.

A realidade primeira de cada uma das ideias universais permanece idêntica em si mesma, apesar de determinar existentes distintos.

5. É bem conhecido que, a despeito de sua inteligibilidade, as ideias universais são desprovidas de realidade própria e que elas não existem a não ser pela sua função atributiva ou poder de reger. Elas são regidas pelos seres determinados aos quais elas se aplicam, sem ser submetidas por isso à separação e à divisibilidade, o que lhes seria impossível. Sua essência é presente em todo ser que elas qualificam; por exemplo, a "qualidade humana" é presente em toda pessoa que faz parte do gênero humano sem ser, nem divisível, nem submetida ao número pelo fato dela se referir à pluralidade de pessoas; e sem cessar de ser inteligível. Se podemos afirmar, assim, uma conexão entre o que é provido de realidade atual determinada e o que é desprovido - uma vez que se trata de relações puramente conceituais - a fortiori poderemos conceber uma conexão, entre os seres que são providos, pois há sempre entre eles um elemento comum - que é a realidade determinada - ausente no primeiro caso. Se a conexão existe na ausência do elemento comum, ela será mais forte e mais verdadeira quando

${ }^{132}$ Ibidem, pp. 49, 50 e 51. 
esse elemento existe. Ora, é indubitável que o ser efêmero é um ser "produzido" que, pelo fato da sua contingência, é dependente de um ser "produtor", sua realidade atual provém de um outro que não é ele mesmo, ao qual está ligado por sua dependência. Em contrapartida, a realidade daquele do qual depende não pode ser senão necessária, pois lhe é essencial; ele se basta nele mesmo em sua realidade e não está sujeito a nada. É, antes, ele que, por sua essência, confere a realidade atual, a este ser efêmero que retira dele sua origem. Como ele implica este ser por sua essência, este é "necessário por ele; como, por outro lado, sua dependência em relação àquele de quem procede sua manifestação é dada - também - a sua essência, essa dependência implica que ele seja segundo sua forma em tudo que lhe é atribuído, quer se trate de um nome ou de um atributo; com exceção, sempre, da necessidade essencial, que é incompatível com o ser efêmero. Ainda que este seja necessário, ele o é, não por ele mesmo, mas por outro que não ele. ${ }^{133}$

As ideias universais existem enquanto inteligíveis e enquanto poder de determinar a existência dos particulares. A essência das ideias universais é presente em todos os existentes que são por ela qualificados e, ainda assim, não se tornam divisíveis.

Pode-se pensar, desse modo, a conexão, sempre inteligível, entre o que é provido de existência atual determinada e o que é desprovido - as ideias universais -, tem-se que, para cada existente determinado, há uma conexão necessária entre ele e a ideia universal que lhe corresponde. Desse modo, qualquer ideia universal subsiste independentemente de estar atualizada em uma existência determinada. Assim, é possível conceber a conexão no interior do existente determinado, ligando-o às suas ideia universais correspondentes. Do mesmo modo, pode-se pensar também, não em cada existente determinado, mas na relação entre eles, ou seja, existentes determinados com existentes determinados. Ora, entre eles existirá sempre um elemento comum: todos são existência determinada. Esse elemento comum estaria presente apenas na relação entre existentes determinados e, ausente, em relação ao primeiro caso, na relação entre cada existente determinado com a ideia universal correspondente - onde há apenas a conexão e não o elemento comum -. Isso significa que, se a conexão existe na ausência do elemento comum, ela será ainda mais forte e mais verdadeira na presença do elemento comum, ou seja, ao se considerar os existentes determinados uns em relação aos outros.

O existente efêmero, dada sua conexão necessária com a ideia universal - que nele está contido, o rege e é por ele regida, sem que, por isso, torne-se menos inteligível, separável ou divisível, permanecendo a mesma, essencialmente, em todos os existentes que 
qualifica - e sua contingência, não pode subsistir por si. Disso, Ibn 'Arabī conclui que os efêmeros são sempre produzidos, enquanto as ideias universais, sempre potencialmente produtoras. Ora, o que é produzido depende do produtor, sendo ambos distintos entre si. Assim, a realidade daquele que gera a realidade atual determinada só pode ser necessária, uma vez que ela é essencial para toda qualificação, auto suficiente e, desse modo, por sua própria essência, confere realidade atual ao efêmero, tornando-se, ela própria, efêmera do ponto de vista do existente determinado.

Assim, o existente efêmero é necessário apenas pela realidade das ideias universais, ou, dito de outro modo, a sua dependência em relação à realidade que o gera é dada pela essência da realidade primeira. Não se pode deixar de considerar que o existente efêmero é necessário, embora não por ele mesmo.

6. Sendo assim, já que, como temos dito, o existente efêmero é manifesto segundo sua forma - da existência geradora -, saiba ainda que o real nos convidou, para obter a ciência sobre ele, a observar esse ser; ele mencionou, com efeito, que ele nos fez ver seus sinais nele, de modo que nós procuramos, em nós mesmos, as indicações que lhe pertencem; as qualificações que nós lhe damos não são outras que nós, com exceção do privilégio da necessidade essencial. Como a ciência que temos dele é obtida por nós e a partir de nós, nós lhe atribuímos tudo aquilo que nós atribuímos a nós mesmos. É dessa maneira que nos chegam as notificações divinas, pelas bocas dos intérpretes. O real descreve-se para nós e por nós: quando nós o contemplamos, nós nos contemplamos a nós mesmos e quando ele nos contempla, é ele mesmo quem ele contempla.

Portanto, nós não duvidamos de que somos numerosos, enquanto indivíduos e enquanto tipos. Nós sabemos muito bem que, a despeito do nosso pertencimento a uma realidade primeira que nos reúne, existe um fator de separação que torna os indivíduos distintos uns dos outros; sem o que não haveria multiplicidade dentro da unidade. Do mesmo modo, ainda que ele - o real - nos atribua as qualificações que atribui a si mesmo, sob todos os aspectos, há, necessariamente, um fator de separação que não é outro senão a necessidade que temos dele, no seio da realidade atual. Nossa existência depende dele, do fato de nossa contingência, já que ele é livre de toda necessidade comparável à nossa: a eternidade retorna a ele, assim como a "primordialidade", que não deve ser confundida com esse começo que define o início da existência, a partir de um estado de não manifestação.

Ainda que ele seja o primeiro, não podemos lhe atribuir nenhum começo; e é por isso que dizemos dele que ele é o último. Se seu começo fosse aquele que marca a existência por um condicionamento, ele não poderia ser o último em relação à 
realidade condicionada, uma vez que não há o último no domínio da contingência; os seres contingentes são uma multidão indefinida que não pode ter fim. Ele é, então, último, unicamente pelo fato de que toda a realidade a ele retorna, depois de nos ter sido atribuída: ele é o último, dentro daquilo que é a essência de sua qualidade de primeiro, e ele é o primeiro, naquilo que é a essência da sua qualidade de último. ${ }^{134}$

O real vendo-se a si mesmo em outro, realiza-se, também, por meio do conhecimento que é possível obter a partir da ciência dos nomes divinos - ciência divina - por meio da aquisição da ciência das ideias universais e suas relações com os existentes determinados. Com essa compreensão, deve-se contemplar os existentes efêmeros, pois, se bem observados, informam sobre sua relação necessária com a realidade primeira, sobre o real. E isso é o mesmo que dizer que o real nos faz ver seus sinais nos existentes efêmeros, para que sua própria vontade, de ver a si mesmo, seja realizada. O que significa perceber a essência no existente determinado, que dela procede, e, pela necessidade essencial, compreender que a essência não difere daquilo que determina. Portanto, as qualificações, que atribuímos à realidade primeira, dizem respeito a nós mesmos. E não haveria como ser diferente, pois tudo que somos capazes de atribuir ao universal, o fazemos pelo que dele encontramos em nós, seja a respeito de qualidades que manifestamos ou a respeito das faculdades que possuímos. Ou seja, não poderíamos atribuir algo, nem inteligir, sem que esse algo estivesse contido em nós, a nos reger segundo sua forma pré-existente.

O que os intérpretes ${ }^{135}$ comunicam é o que a ciência divina comunica de si por meio deles. Uma única visão compõe-se de duas perspectivas que, plenamente incorporadas na enunciação desse autor, revelam-se unidas, como: "quando nós o contemplamos, nós nos contemplamos a nós mesmos e quando ele nos contempla, é ele mesmo quem ele contempla"136.

Ao completar-se, desse modo, a realização da vontade divina do real de ver a si mesmo a partir de outro, quando ocorre o reconhecimento da essência por um existente efêmero, algo nesse existente parece agora retornar a si mesmo enquanto real, retornando a sua condição original, essencial. Esse retorno à realidade primeira, dá-se por meio daquele que compreende que pertence à realidade primeira e que dela não difere, senão pelo fato de se encontrar existencialmente determinado, assumindo também as qualidades de um existente efêmero e, por tais determinações, saber que depende total e necessariamente do real, embora compreenda que dele não difere e apenas nele subsiste.

\footnotetext{
${ }^{134}$ Ibidem, pp. 53 e 54.

135 Profetas, anjos, santos, herdeiros.

${ }^{136}$ Ibidem, pp. 53 e 54.
} 
Nesse círculo dos existentes determinados no interior do real, que se completa no retorno a si mesmo, atualiza-se o retorno dos universais. A essência fluída em toda forma determinada, através da ciência de si, retorna ao que ela nunca deixou de ser e sem que precise deixar de estar determinada, pois a visão do real continua na medida em que o outro continua sendo.

As atribuições que a realidade primeira atribui a si mesma são atribuídas a nós e encontram-se reunidas em Adão - aquele que reúne todos os atributos divinos. Assim, através da conexão essencial que temos todos com Adão, essas atribuições nos regem segundo a forma da realidade primeira. Enquanto existentes na realidade atual, da realidade primeira estaremos separados, mas essa separação não é nada de outro, senão a nossa necessidade e total dependência da fonte que nos gerou, que subsiste em nós e na qual existimos, uma vez que somos dela manifestos como atuais e determinados e, assim, plenamente estabelecidos na relação senhorial.

A realidade primeira, sendo incondicionada, não possui um começo, dessa maneira, se dela se diz que é primeira e última, é porque dela tudo procede e a ela tudo retorna, ou seja, apenas se pode dizê-lo, a partir da perspectiva da realidade essencial.

7. Saiba igualmente que o real descreveu-se como exterior e interior; então, ele fez existir o mundo como oculto e manifesto, a fim de que nós compreendêssemos o interior, através de nosso aspecto oculto e, o exterior, através de nosso aspecto manifesto. Ele se qualificou também pela satisfação e pela cólera; então, ele fez existir o mundo dotado de temor e esperança: o temor de sua cólera e a esperança de sua satisfação. Ele se descreveu ainda como belo e dotado de majestade; então, ele nos fez existir no temor reverencial e na intimidade familiar. Do mesmo modo, para tudo que o altíssimo atribuiu-se e pelo que se designou. Suas qualificações complementares são representadas pelas duas mãos, estendidas por ele, em vista da criação do homem perfeito, uma vez que, esse reúne tão bem as realidades universais do mundo, assim como seus elementos. O mundo está manifesto e o califa é seu mistério oculto. É por isso que o soberano permanece invisível e que o real descreve-se como oculto pelos "véus de sombra...", que são os corpos grosseiros, “... e de luz" que são os espíritos sutis. O mundo é composto desses dois aspectos; ele é para ele mesmo seu próprio véu e não pode compreender o real como o real compreende a si mesmo; ele permanece velado para sempre, ainda que saiba que é distinto de seu existenciador, pelo fato da sua dependência; não há qualquer parte para a necessidade essencial que seja própria à realidade do real e não poderá jamais compreendê-lo. Essa verdade essencial torna o 
real impossível de ser conhecido, para sempre, pela experiência e a contemplação direta; o efêmero não pode acessá-lo.

Deus reuniu suas duas mãos para a criação de Adão, unicamente em vista de mostrar sua excelência; é por isso que ele disse a Iblīs: "O que lhe impede de te prostrar diante daquele que criei com minhas duas mãos?", não designando por isso, senão a reunião das duas formas: a forma do mundo e a forma do real, que são as duas mãos de Deus. Iblīs é um elemento do mundo; ele não possui essa qualidade sintética.

É por isso que Adão é califa. Se ele não tivesse se manifestado na forma daquele que o propôs e investiu, ele não seria califa; se ele não tivesse, em si, tudo que procuram seus sujeitos - uma vez que é dele que dependem, de tal modo que ele deve necessariamente realizar todas as suas necessidades - ele não teria se estabelecido sobre eles como califa. Somente o homem perfeito é digno do califado, de modo que o altíssimo constituiu sua forma exterior a partir das realidades essenciais do mundo e, a partir de suas formas, e sua forma interior segundo sua própria forma. É por isso que ele disse a seu respeito: "Eu sou seu ouvido e sua orelha", ele distinguiu as duas formas. No restante, ele é assim para todos os seres existentes que fazem parte do mundo, na medida em que requerem a essência particular desse ser. Entretanto, ninguém possui a reunião sintética daquilo que pertence ao califa: é pela síntese que ele triunfa. ${ }^{137}$

O real descreveu a si mesmo como o exterior - al-zāhir - e o interior - al-bātin -, tendo manifestado o mundo conservando esse duplo aspecto para que possa ser conhecido pelo homem, tanto através da contemplação de seu próprio interior como pela contemplação de toda existência determinada. Ele também descreveu-se pela qualidade do temor e da cólera e manifestou o mundo como um lugar de crença e esperança. Descreveu-se ainda pela beleza e majestade, dotando os homens de crença reverencial (al-hayba) e intimidade (al'uns). E, assim por diante, em relação a tudo que se refere a ele e, pelo qual, designou-se na totalidade de seus atributos. Adão representa, por sua constituição, as duas mãos de Deus, a saber, os dois aspectos complementares que são a essência e a existência determinada ${ }^{138}$, ou, o que é o mesmo, a forma sintética - que reúne desde as ideias universais até os elementos.

O mundo é o externo aparente, enquanto a realidade adâmica, o oculto que subsiste em toda determinação. É por isso que o califa, forma total que por seu posto reflete o real na sua totalidade atributiva, permanece invisível. Nesse sentido é que o real diz esconder-se atrás dos véus - que são os corpos naturais - e dos véus de luz - que são os

\footnotetext{
${ }^{137}$ Ibidem, pp. 54, 55 e 56.

138 Posteriormente, essa qualificação de Adão será importante para compreender a qualificação que o autor atribui, por extensão, à mulher, ao perfume e à prece ritual no vigésimo sétimo capítulo.
} 
espíritos sutis, pois o mundo é feito de substância grosseira (kāthīf) e de substância sutil (latīf). O mundo é para si mesmo seu próprio véu, não pode ver o real - como o real veria a si mesmo sem outro - pois jamais pode desfazer-se de seu véu, sabendo que está ligado por dependência a seu criador. Desse modo, o mundo não participa da autonomia do real e não o concebe jamais.

Ibn 'Arabī prepara-se para finalizar o primeiro capítulo, falando diretamente ao leitor, lembrando-o de que, desse modo, pode conhecer o significado espiritual da criação do corpo de Adão, isto é, da sua forma aparente e da "criação" do seu espírito, que é sua forma interior. Compreendendo que Adão é o real e é criatura, é a "alma única" (an-nafs al-wāhida) provedora do gênero humano.

Segundo o autor, o leitor deve dimensionar-se diante do real, deve buscar compreender a si mesmo e, ao compreender-se na relação com a essência divina, assistir à realização da vontade do real de ver a si mesmo. Assistir nos dois sentidos, de quem observa, percebe, conhece, e de quem cuida, dela se ocupa, vela, protege, nutre, enquanto compreende o que se cumpre, através de cada criatura, na realidade do criador - que não é diferente dele, senão apenas por necessidade essencial.

Dessa forma, Ibn'Arabī, segundo ele mesmo, pôde contemplar o que lhe foi permitido expor nesse livro, porque lhe foi dada a visão do que o real inseriu no interior do gerador primordial, de modo que, daquilo que lhe foi permitido transcrever nesse livro, o presente capítulo trata da sabedoria divina atribuída ao nome de Adão. E assim, também desdobram-se os demais capítulos que tratam, cada um por seu nome, dos atributos que manifestam as qualidades essenciais da sabedoria que envolve a profecia.

8. Se o real não fosse onipresente nos existentes, por meio da forma - total -, o mundo não teria nenhuma realidade atual; do mesmo modo, sem essas realidades inteligíveis e universais - acima mencionadas -, nenhuma função atributiva poderia manifestar-se na existência determinada. Tal é a verdade primeira que explica a dependência do mundo, em relação a Deus, na sua realidade atual. O todo é dependente. Nada pode bastar-se. Tal é a realidade que nós dizemos sem rodeios.

Se você menciona um existente que seja auto suficiente, sem qualquer dependência, você sabe muito bem aquele de quem falamos. O todo é ligado ao todo; nenhuma separação é possível. Torne seu aquilo que acabo de dizer. Você conhece agora a sabedoria da constituição de Adão, quero dizer, da sua forma exterior; você conhece a constituição do espírito de Adão, quero dizer, da sua forma interior, uma vez que ele é 
o real-criatura; você conhece a constituição de seu estatuto, que é a "reunião sintética", que o torna digno do califado. ${ }^{139}$

Nessa passagem, o autor ressalta a unidade que impera e preside toda a existência. Unidade, na qual, está perfeitamente implicada toda determinação. Refere-se ao mundo existenciado como o real-criatura, a face criatura do real que dele não difere, senão por sua dependência dele, nem encontra-se dele separada. Trata-se do uno sempre, o real sempre onipresente em cada existente. A dependência da criatura relativa ao real é total.

9. Adão é uma "alma única", a partir da qual, o gênero humano foi criado, segundo a palavra do altíssimo: 'Ó homens! Temei a vosso senhor que os criou a partir de uma alma única, que criou, a partir dela, sua esposa e que produziu, a partir desse casal, uma multidão de homens e mulheres'. ${ }^{140}$ Sua palavra "temei vosso senhor" significa: “façam de vosso exterior, uma proteção para o vosso senhor e, do vosso interior, que é vosso senhor ele mesmo, uma proteção para vocês; uma vez que a ordem comporta censura e louvor, assim vós sereis daqueles que respeitam as conveniências e possuem a ciência. ${ }^{141}$

Com isso, toda existência determinada, encontra em Adão, sua própria alma. Todos os homens compartilham uma só alma, dela dependem e por ela existem. Sua condição de existência é dada por meio da forma adâmica.

10. A seguir, o altíssimo lhe mostrou o que ele confiou a esse imã, o genitor supremo, eu transcrevo, nesse livro, a parte em que ele traçou os limites, não aquela da qual tive conhecimento, pois isso nenhum livro, nem mesmo o mundo presente, poderia contêlo.

Através do que contemplei e transcrevi nesse livro, dentro dos limites que foram traçados para mim, pelo enviado de Deus - que Deus derrame sobre ele sua graça unitiva e sua paz! -, há:

uma sabedoria divina em um nome de Adão é o primeiro capítulo;

a seguir, uma sabedoria encantatória em um nome de Sete;

a seguir, uma sabedoria transcendente em um nome de Noé;

a seguir, uma sabedoria extremamente santa em um nome de Enoque;

a seguir, uma sabedoria perdida de amor em um nome de Abraão;

a seguir, uma sabedoria de verdade em um nome de Isaac,

a seguir, uma sabedoria sublime em um nome de Ismael;

a seguir, uma sabedoria espiritual em um nome de Jacó;

${ }^{139}$ Ibidem, pp. 57 e 58.
${ }^{140}$ Cor., $4,1$.
${ }^{141}$ Ibn 'Arabī, Le livre des chatons des sagesses, op. cit., pp. 58 e 59. 
a seguir, uma sabedoria luminosa em um nome de José;

a seguir, uma sabedoria de verdade em um nome de Éber;

a seguir, uma sabedoria das aberturas em um nome de Selá;

a seguir, uma sabedoria do coração em um nome de Jetro;

a seguir, uma sabedoria da força intensa em um nome de Ló;

a seguir, uma sabedoria da citação existencial em um nome de Uzayr;

a seguir, uma sabedoria profética em um nome de Jesus;

a seguir, uma sabedoria toda-misericordiosa em um nome de Salomão;

a seguir, uma sabedoria da realidade atual em um nome de David;

a seguir, uma sabedoria da alma em um nome de Jonas;

a seguir, uma sabedoria secreta em um nome de Jó;

a seguir, uma sabedoria majestosa em um nome de João Batista;

a seguir, uma sabedoria real em um nome de Zacarias;

a seguir, uma sabedoria íntima em um nome de Elias;

a seguir, uma sabedoria de realização perfeita em um nome de Lukman;

a seguir, uma sabedoria do imã em um nome de Aarão;

a seguir, uma sabedoria da eminência em um nome de Moisés;

a seguir, uma sabedoria do sustentáculo universal em um nome de Khālid;

a seguir, uma sabedoria incomparável em um nome de Muhammad.

O engaste de toda sabedoria é o nome ao qual ela corresponde. Eu fui censurado, em tudo que mencionei a respeito dessas sabedorias nesse livro, ao limite fixado na mãe do livro. Obedeci ao que me foi prescrito; respeitei os limites que me foram fixados. Teria eu desejado e acrescido, não teria conseguido, uma vez que a presença nisso me teria impedido. E Deus concede o êxito. Não há outro senhor além dele.

E, do que diz respeito a isso, faz parte ${ }^{142}$ [os demais capítulos do Fuṣūṣ].

${ }^{142}$ Assim termina a última frase do primeiro capítulo. 


\section{O engaste e a sabedoria de Muhammad}

1. Sua sabedoria é incomparável uma vez que ele é o mais perfeito dos existentes entre o gênero humano. É por isso que este teve início e foi selado por ele: ele era profeta "enquanto Adão ainda estava entre a água e a argila"; além disso, do ponto de vista de sua constituição corporal, ele se tornou o selo dos profetas.

O primeiro número ímpar ${ }^{143}$ é três; os números que seguem essa primordialidade, na ordem dos números ímpares, dele procedem. ${ }^{144}$

A atribuição da incomparabilidade à sabedoria muhammadiana face às demais é a primeira característica utilizada para identificar o profeta Muhammad. Tal sabedoria pode manifestar-se por encontrar, na forma adâmica, seu receptáculo. Enquanto Adão é regido pelo nome "o misericordioso", nome através do qual todos os nomes viajam, Muhammad, por sua vez, é portador da sabedoria de todos os nomes contidos em Adão.

Com o profeta Muhammad, o gênero humano conheceu a sua forma determinada mais perfeita pois trata-se da determinação de um existente cuja ciência abarca a essência de todos os atributos divinos, a ciência mais próxima do real.

A ideia universal de profecia - que permanece inalterável e pré-existe à qualquer determinação - corresponde ao que, no texto, é dito como sendo a sabedoria própria do profeta Muhammad, a ciência divina, aquela que, por meio da forma adâmica, atualiza-se em uma existência determinada na forma do profeta Muhammad, a quem se atribui também a qualidade de selo.

A atualização da ideia universal de profecia e da ideia universal de humanidade, operada por meio da forma determinada do profeta Muhammad, é a atualização plena, máxima, de toda potência que tanto o gênero humano como a profecia encerram.

É nesse sentido que se pode pensar a condição de todos os múltiplos existentes como sendo dada por essa configuração originária entre o real, Adão e Muhammad, pois Muhammad antes de se manifestar como um profeta - tal como conhecemos historicamente, isto é, como um existente efêmero -, ele já existia enquanto sabedoria do real - ciência do real - e é essa sabedoria procedente do real que exige a existenciação de Adão, seu receptáculo perfeito. Assim, pode-se afirmar que da união da essência que procede do real enquanto sabedoria muhammadiana com a forma perfeita de Adão constitui-se não só a

\footnotetext{
${ }^{143}$ Sempre que a expressão "número ímpar" for citada aqui, entenda-se: números ímpares a partir do três.

${ }^{144} \mathrm{Ibn}$ 'Arabī, Le livre des chatons des sagesses, op. cit., p. 687.
} 
possibilidade de manifestação de toda a multiplicidade dos existentes, como também o contínuo e incessante fluxo da essência por meio das formas determinadas.

2. Ele é a prova mais perfeita de seu senhor uma vez que as palavras sintéticas lhe foram dadas, que são os "nomeados" correspondentes aos "nomes" que Adão recebeu.

Ele se parece com a prova lógica que comporta também a tríade. A prova é uma prova por ela mesma. ${ }^{145}$

A prova mais perfeita de seu senhor, como a conclusão que contém as duas premissas que lhe são necessárias, Muhammad possui, além dos nomes todos, tudo aquilo que potencialmente está contido no nome e se revela através dele, a saber, a essência do real. Nada disso lhe é exterior, tudo isso lhe é essencial e necessário.

Ibn’Arabī utiliza-se, em seus escritos, muitas vezes da expressão "faça a síntese!", ou seja, realize a compreensão da natureza daquilo que observa, desse modo, pode-se considerar aqui que as palavras sintéticas são aquelas sobre as quais recai a síntese, ou seja, a sabedoria própria de cada nome.

Sua realidade essencial the conferia, pela triplicidade de sua constituição, a qualidade de número ímpar primordial; é por isso que ele disse a propósito do amor que é o princípio dos seres existenciados: "Foram-me dadas como dignas de amor três coisas pertencentes ao vosso baixo-mundo..." pelo fato da tríade presente nele; depois ele mencionou as mulheres, o perfume e o fato de que "o frescor de seu olho" fora inserido na prece ritual. ${ }^{146}$

É importante considerar o que se diz quando o autor afirma ser a mulher uma parte do homem $^{147}$. Do ponto de vista essencial, se Adão representa o homem perfeito, ou a forma a partir da qual se origina a multiplicidade dos existentes, as mulheres assim como os homens encontram em Adão sua origem. Isso quer dizer que tanto as mulheres como os homens, guardam essa relação de dependência necessária com o que lhe constitui essencialmente.

A triplicidade da constituição de Muhammad abarca a tríade formada pelo real, Adão e Muhammad, ou dito de outro modo, abarca: 1. a essência do real que viaja, 2. através dos nomes divinos, 3. revelando as sabedorias divinas.

\footnotetext{
145 Ibidem, pp. 687 e 688.

146 Ibidem, p. 688.

${ }^{147}$ Antes de mais nada, não cabe aqui, porque não é esse o interesse da presente pesquisa, qualificar o discurso do autor no sentido de apontar a qualificação secundária que confere à mulher em relação à primazia conferida ao homem. Ao invés de não traduzir os parágrafos que a esse aspecto fazem referência e deixar de incorporá-los no corpo do presente texto, escolho mantê-los apenas porque oferecem mais um exemplo aplicativo da dinâmica presente na imagem do engaste para que fique ainda mais evidente o modo como deve proceder aquele que busca conhecer a essência do real no modelo cognoscente proposto por Ibn 'Arabī e como ele o aplicou no caso do profeta Muhammad.
} 
Toda hierarquia, no sistema ackbariano, encontra-se necessária e essencialmente configurada em uma tríade, sempre procedente da tríade fundamental e prototípica mencionada acima. A estrutura tríptica é o que garante a simultaneidade dos movimentos existencial e gnoseológico, a expansão e o retorno, a multiplicidade e a unidade, o segredo e a revelação, etc.

Ele começou pela menção das mulheres e terminou pela prece, e isso porque a mulher é uma parte do homem pela origem da manifestação de seu ser. Ora, o conhecimento que o homem tem dele mesmo precede o conhecimento que ele tem de seu senhor, uma vez que este é a consequência do primeiro; por isso, ele disse também - sobre ele a paz! -: "Aquele que conhece a si mesmo conhece seu senhor". Você pode compreender esse dado, seja no sentido de que esse conhecimento é impossível e que é incapaz de chegar a ele - uma vez que esse sentido é permitido -, seja como uma confirmação desse conhecimento. Segundo a primeira interpretação, você sabe que você não conhece sua alma de modo que você não pode conhecer seu senhor: pela segunda, você a conhece, e você conhece, por consequência, seu senhor.

Muhammad - que deus derrame sobre ele sua graça unitiva e sua paz! - é a prova mais evidente de seu senhor uma vez que todas as partes do mundo são uma prova do princípio do qual procedem e que é seu senhor. Compreenda então! ${ }^{148}$

Nesse parágrafo, o autor refere-se a uma certa hierarquia correspondente ao processo existencial, o que exige o entendimento do modo como as substâncias são atualizadas em cada existente determinado. O significado do senhorio, da relação senhorial, é o equivalente da relação de dependência, absolutamente necessária, da forma determinada de qualquer existente em relação à essência. Se assim é, então aquele que, na tarefa de conhecer sua verdadeira natureza, chegar à apreensão de sua essência, conhecerá seu senhor. Não há como conhecer-se, de fato, sem conhecer também seu próprio princípio, tratado aqui como senhor.

3. As mulheres se lhe tornaram dignas de amor. Ele experimentava por elas a atração que o todo experimenta pela sua parte. Através disso, ele desvelou a realidade metafísica verdadeira expressa em sua palavra sobre a constituição corporal do homem: "E eu insuflei nele desde meu espírito"149, seguido dessa outra, onde ele se descreve como animado do desejo ardente de reencontrá-lo; ele disse, com efeito, a respeito daqueles que o desejam ardentemente: “- Ó amigo de Deus! Meu desejo de reencontrá-los é mais intenso ainda!"

Trata-se de um encontro particular, pois é dito no hadīt sobre o ante-cristo: "Nenhum de vocês verá seu senhor antes de morrer". Como não haveria nisso um desejo ardente

148 Ibn 'Arabī, Le livre des chatons des sagesses, op. cit., p. 689.

149 Cor., 15,29 ; 38,72. 
daquele que possui essa qualificação! Deus deseja seus entes próximos, a despeito do fato que ele os vê; aquilo que ele deseja, é que eles o vejam mesmo que sua condição lhes impeça. Esse hadīt é semelhante a sua palavra: "Até que saibamos"150, a despeito do fato que ele possui a ciência! Deus deseja ardentemente essa qualificação particular que não pode ser atualizada senão no momento da morte. É por ela que ele apazigua o desejo ardente que têm dele; assim como ele disse no "hadīt da hesitação" que evidencia o mesmo ensinamento: "Em nenhuma das coisas que realizo, minha hesitação é comparável à que experimento ao retomar o sopro do meu servo crente que detesta a morte; eu detesto fazê-lo mal, mas é necessário que ele me reencontre" 151 . Ele the anuncia uma boa nova; ele não lhe diz: "é preciso necessariamente que ele morra", para não entristecê-lo com a menção à morte. De qualquer modo, como Deus não pode ser encontrado, senão após a morte, conforme o que disse o profeta - sobre ele a paz! - : "Nenhum de vocês verá seu senhor antes que morra", o altíssimo disse: "É preciso necessariamente que ele me encontre". O “desejo ardente" de Deus é motivado pela existência dessa relação: O amado deseja ardentemente ver-me e meu desejo dele é ainda mais intenso. Os corações batem de um desejo que o decreto divino contraria. Eu me inclino gemendo; ele se inclina gemendo. Tendo declarado que "insuflou nele desde seu espírito", não há desejo ardente senão em relação a ele mesmo. Você não vê que ele criou, segundo sua forma, porque é originário do seu espírito? ${ }^{152}$

O ser humano fora qualificado também pelo desejo ardente de ver o seu senhor. Sobre isso, nosso autor explica que tal qualificação, na existência determinada, devese a sua origem essencial, pois deriva da vontade do real de reunir-se ao seu servo. Por isso, Deus determina existencialmente um ser humano, qualificando-o também como mortal. A morte é apresentada, nessa passagem, como um atributo essencial regido pela essência do real, de acordo com sua vontade de novamente reunir-se em si mesmo, de modo que as existências determinadas retornem, por meio da morte e da possibilidade de vê-lo, a sua forma universal essencial.

Como a constituição humana é composta desses quatro elementos que chamamos "humores" enquanto estão presentes no corpo do homem, sua insuflação produz uma incandescência em contato com a umidade que esse corpo conserva; essa constituição faz surgir então o espírito do homem como um fogo. É por isso que Deus falou a Moisés sob a forma de fogo e que ele, assim, fez a forma de sua necessidade. Se a

\footnotetext{
${ }^{150}$ Cor., 47, 31.

${ }^{151}$ Bukhārī, 81,38.

${ }^{152} \mathrm{Ibn}$ 'Arabī, Le livre des chatons des sagesses, op. cit., pp. 689, 690 e 691.
} 
constituição do homem fosse evidente, da natureza primordial, seu espírito seria uma luz. Deus utilizou a esse respeito a imagem da insuflação para indicar que procede do sopro do todo misericordioso. É pelo sopro constitutivo que sua própria essência é manifesta; e é pela pré-disposição do receptáculo, em que essa insuflação se produz, que a incandescência, nele, aparece como "fogo" e não como "luz". O sopro divino se interioriza, assim, dentro daquilo que faz com que um homem seja um homem. ${ }^{153}$

No ser humano, a essência do real, ao entrar em contato com sua forma correspondente na existência determinada de cada homem, produz, pelas qualidades físicas do corpo físico receptáculo -, fogo, o que, do ponto de vista essencial é luz. Com isso, o autor descreve de que modo a essência fluida do real, representada pelo sopro que procede do real para todo receptáculo, encontra-se no interior de cada existente determinado.

4. Em seguida, tirou dele, e para ele, alguém que ele chamou "mulher". Ela surgiu, segundo a forma do homem que experimentara por ela a viva atração que uma coisa tem por ela mesma; de sua parte, ela experimentara, por ele, a atração que uma coisa experimenta por seu país natal. As mulheres "lhe foram dadas como dignas de amor", uma vez que Deus ama aquele que ele criou segundo sua forma e diante de quem ele fez prostrarem-se os anjos de luz, a despeito da imensidão da sua potência e de seu grau, da eminência de sua constituição tirada da natureza primordial; é daqui que vem essa afinidade. A forma constitui a maior afinidade, a mais magnificente e a mais perfeita; ela é o cônjuge que torna dupla a realidade atual de Deus, da mesma maneira que a mulher redobra o homem por sua existência e o faz aparecer como "esposa".

Uma nova tríade surge assim, composta de Deus, do homem e da mulher. O homem experimenta pelo seu senhor, que é seu princípio, a atração que a mulher experimenta por ele. Seu senhor lhe fez serem as mulheres "dignas de amor" da mesma maneira que Deus ama aquele que é segundo sua forma. Não ama senão um ser existenciado a partir dele, mas seu amor pertence a aquele a partir do qual ele foi existenciado, e que é Deus. É por isso que ele disse "foram-me dadas como dignas de amor", e não "eu amei" como se esse amor tivesse vindo dele mesmo, pois seu amor dependia de seu senhor; ele era "segundo sua forma" até no amor que ele sentia por sua mulher: ele a amava do amor que Deus sentia por ele, revestido assim de um caráter divino. ${ }^{154}$

O amor, como princípio dos seres existenciados, parece remontar ao sentimento que o real teria por cada existente, pois se revela como o desejo ardente e a forte atração que o todo manifesta por cada uma de suas partes. Cada existente, por sua vez, experimenta pelo todo, pelo seu senhor, amor, o desejo ardente e a mesma atração. Apenas a equivalência em grau

153 Ibidem, pp. 691 e 692.

154 Ibidem, pp.692 e 693. 
não se dá, pois o senhor sofre de um amor muito mais intenso, tal a sua ciência, ou ainda, dada a sua natureza, o real é o único existente.

O amor de cada homem por sua respectiva esposa e o amor da esposa por seu esposo não existem, senão pelo fato de que esse amor procede do amor divino. O homem atualiza o amor de Deus, por meio do amor que sente pela esposa. O esposo ama a sua esposa, pelo mesmo amor que seu senhor experimenta por ele e, na medida em que esse amor procede na direção da sua esposa, obedece à mesma configuração da tríade de origem compreendida pelo real, Adão e Muhammad. Assim também, a mulher atualiza, pelo amor que dedica a seu esposo, o mesmo amor que o homem experimenta por seu senhor. No amor de um casal, o amor divino realiza-se também no duplo aspecto exigido pela relação senhorial.

Como o homem ama a mulher, ele procura unir-se à ela, quer dizer, procura a união mais completa no amor. Ora, a forma da sua constituição corporal não comporta uma união maior que a união sexual. A volúpia invade assim todos os seus membros. É por isso que ele ordenou purificar-se dessa união, através da grande ablução: a purificação é geral, assim como fora a extinção no interior da mulher no momento da volúpia suprema. Deus é muito ciumento de seu servo quando este passa a acreditar que ele experimenta um gozo com outro que não é ele; ele o purifica através da grande ablução a fim de que ele retorne, novamente, seu olhar para ele, no interior do ser no qual ele está; uma vez que se trata unicamente disso. ${ }^{155}$

A purificação só se faz necessária, segundo o autor, quando o homem ou a mulher esquecemse de quem, verdadeiramente, estão a amar. E também por causa de sua constituição física, porque de acordo com ela, a maior união só se dá por meio da união sexual e nela, tanto o homem, quanto a mulher, experimentam a volúpia que decorre de tal união. No entanto, a purificação não é senão o recobrar-se da verdadeira compreensão do significado e da natureza do amor, da atração e da suprema volúpia, que gera a extinção dentro da mulher, ou seja, o êxtase do reconhecimento decorrente da união divina mais poderosa.

Quando o homem contempla Deus em uma mulher, ele contempla o polo pacífico; quando ele o contempla em si mesmo sob o aspecto da mulher que fora existenciada a partir dele, ele o contempla enquanto polo ativo; enfim, quando ele o contempla, em si mesmo, sem que lhe esteja presente a forma daquele que procede dele, ele contempla um ser cujo estado é passivo em relação a Deus, sem intermediário. Sua contemplação de Deus, na mulher, é portanto mais completa e mais perfeita, pois ele o contempla, então, através de seu aspecto ativo e através de seu aspecto passivo. Essa é a razão

155 Ibidem, pp. 693 e 694. 
pela qual o profeta - que Deus derrame sobre ele sua graça unitiva e sua paz! - amava as mulheres: nelas, a contemplação de Deus é mais perfeita. ${ }^{156}$

Nessa passagem, o autor refere-se ao duplo caráter da obediência: servil e senhorial, que implica que o homem possa contemplar a Deus - através do amor divino pelo seu senhor e pela sua esposa - como intermediário, entre Deus e as mulheres, assim como é Adão, intermediário entre Deus e os homens.

Dessa forma, o homem pode realizar a contemplação de Deus adotando o sentido ascendente, exercendo-se enquanto polo passivo, e, no sentido descendente, exercendo a relação de senhorio em sua dimensão ativa. A completude da constituição da forma de Adão exige o duplo modo de contemplar o real.

Todo aquele que, na perspectiva da tríade original, coloca-se como intermediário entre dois polos, pode exercer a contemplação plena de sua condição, realizando-a de forma mais completa. O que significa que, sem amar sua esposa a partir de tal ciência, sua contemplação de Deus não alcançará a perfeição, não alcançará o que seu senhor dele espera, através do que lhe disponibiliza por sua constituição essencial, ao amá-lo como seu servo, de um desejo sempre muito ardente. Mas se o homem esquecer-se da natureza e da função do amor que estiver experimentando por sua esposa, se ele se esquecer de quem verdadeiramente ama, ao amar sua esposa, se esquecer-se de quem é que está verdadeiramente experimentando esse amor por ela e o que é de fato esse amor, Deus saberá que está a amar a outro em ignorância, esquecido de si e de seu senhor, e o purificará, para que retorne novamente seu olhar sobre ele e o desejo divino volte a ser, novamente, atualizado na existência determinada.

Deus não pode jamais ser contemplado na ausência de um suporte, pois a essência de Deus é independente dos mundos. A realidade é inacessível sob esse aspecto, de sorte que a contemplação implica, necessariamente, um suporte sensível; é por isso que a contemplação de Deus, nas mulheres, é a melhor e a mais perfeita.

A maior união é a união sexual. Ela é comparável ao que é a auto-orientação divina em direção a aquele que ele criou, segundo sua forma, para estabelecer como califa, de modo que ele pudesse ver a si mesmo nele. Ele o dispôs harmonicamente, ele o equilibrou, ele insuflou nele seu espírito que é seu sopro. Seu exterior é criatura, seu interior é Deus. É por isso que ele lhe atribuiu o poder regente sobre o santuário dizendo - que ele seja exaltado -: "Ele dirige o comando desde o céu (...)" que

156 Ibidem, pp. 694. 
significa a elevação “(...) até a terra"157 que é o mais baixo dos céus que são baixos, posto que ela é o mais baixo dos elementos. ${ }^{158}$

Como já foi visto, a contemplação do real depende, necessariamente, da existência determinada. Se toda contemplação da essência depende de um receptáculo - existência determinada -, e se, ao estar unido, através da união sexual, com uma mulher, o homem encontra a sua condição mais perfeita para contemplar o real, não há, para o homem, melhor forma de contemplá-lo, senão por meio da mulher.

Ibn 'Arabī compara a união sexual à auto-orientação da vontade divina de ver a si mesmo. A maneira como o homem, na qualidade de esposo, encontra-se ligado, próximo e unido a Deus, é comparável ao modo como o a mulher encontra-se unida a seu esposo.

Assim, a mulher serve de espelho para que o homem veja a si mesmo, no modo ativo em relação ao amor de seu senhor. E ela, na união com seu esposo, contempla-se a si mesma passivamente. Nesse ponto, o duplo aspecto, que a contemplação do real exige, encontra-se simultaneamente presente em tal união - quando o homem e a mulher se unem, por meio dos dois, também temos a união do polo passivo e do polo ativo ${ }^{159}$ - . Considerando ainda que a partir dessa união, da mulher procedem outros seres e assim por diante. Configurando, desse modo, outra tríade, que, por sua vez, procede das anteriores.

A essência que flui por processão do real, procede sempre de algo que lhe é anterior como causa necessária, o que aparece na hierarquia inerente às tríades dos existentes, desde a tríade original. A seguir, essas considerações voltam a fazer referência à trindade primordial que, com a mulher, assume uma trindade de terceiro grau ${ }^{160}$, mas que é da primeira originária. Essa escala trinitária seria reproduzida a partir do primeiro posto, o de Adão, seguindo os demais postos da existência, sempre guardando, não importa em que posto se dê, a inerente correspondência à trindade que preside o primeiro dos postos, aquele ocupado pelo califa. Essa escala pode ser observada, tanto no mundo das formas determinadas, quanto no mundo das ideias, de modo que todo homem é regido por tais princípios em todos os aspectos de sua existência.

E, porque a condição humana foi assim constituída, embora esteja situada na Terra - o mais baixo dos céus -, ela está essencialmente conectada ao mais alto posto.

5. (...) Ele as amou unicamente em razão de seu posto, que exprime a passividade. Elas eram, para ele, o que a natureza primordial é para Deus, que fez eclodir nelas as

\footnotetext{
${ }^{157}$ Cor., 32,5.

${ }^{158} \mathrm{Ibn}$ 'Arabī, Le livre des chatons des sagesses, op. cit., pp. 694 e 695.

${ }^{159}$ Referente ao amor divino, que exige o duplo aspecto da obediência: servil e senhorial.

${ }^{160} \mathrm{O}$ primeiro grau é representado por Adão, o segundo pelo homem, o terceiro, pela mulher.
} 
formas do mundo, graças à "auto-orientação" da sua vontade e ao comando divino que é a "união sexual" no mundo das formas individuais, energia espiritual, no mundo dos espíritos e ordem das premissas, no mundo das ideias, em vista de chegar a uma conclusão. Tudo isso, em todos os aspectos, não é outro, senão a "união conjugal" inerente à qualidade do número ímpar primordial. ${ }^{161}$

O profeta amou as mulheres, a partir da ciência mais elevada, realizando, por meio de sua união com as mulheres, o mesmo que o real realiza por meio de Adão, conforme a vontade do real de ver a si mesmo, em outro. A unidade, que envolve a tríade: o real, Adão, e a existência determinada, encontra, na união conjugal, a sua maior correspondência. Essa relação trinária determina a existência de toda multiplicidade dos seres.

Aquele que ama as mulheres dessa maneira, as ama de um amor divino, ao passo que aquele que as ama de um desejo natural, perde a ciência desse desejo: trata-se, para ele, de uma forma sem espírito - ainda que ela seja dotada de espírito segundo a verdadeira realidade. $(\ldots)^{162}$

Nas condições provenientes do desejo natural, o homem não realiza a vontade do real. É preciso a ciência do amor divino para que a esposa seja, para o esposo, o espelho capaz de refletir a essência, ou a forma que torna visível o espírito, que o revele ao invés de velá-lo.

(...) Assim como o posto da mulher é inferior ao do homem, segundo sua palavra: os homens possuem um grau de superioridade sobre elas ${ }^{163}$, aquele que foi criado, segundo a forma, ocupa um posto inferior àquele que o constituiu assim, apesar do fato que ele é segundo sua forma. Esse grau distintivo é aquele pelo qual Deus é independente dos mundos e "agente primordial", enquanto a forma é "o agente segundo"; ela não possui essa primordialidade que pertence unicamente a Deus. ${ }^{164}$

Apenas o real subsiste por si mesmo, sendo o único existente por si, os demais existentes que dele procedem, encontram nele a causa e o fundamento de sua existência. Por isso a primazia é devida apenas ao real e não a qualquer uma de suas criaturas. Toda forma é conforme a essência, é por ela criada, regida e permanece a serviço dela.

São seus postos que distinguem os seres. O todo conhecedor concede a tudo, que tendo direito, o direito que lhe cabe. É por isso que o amor que Muhammad - sobre ele a graça e a paz! - tinha em relação às mulheres decorria da manifestação de um amor divino, pois Deus confere a todas as coisas sua criação ${ }^{165}$, o que é a essência

\footnotetext{
161 Ibidem, p. 696.

${ }^{162} \mathrm{Ibn}$ 'Arabī, Le livre des chatons des sagesses, op. cit., pp. 696 e 697.

${ }^{163}$ Cor., 2, 228.

${ }^{164} \mathrm{Ibn}$ 'Arabī, Le livre des chatons des sagesses, op. cit., cap.27, p. 697.

${ }^{165}$ Cor., 20,50 .
} 
mesma de seu direito; Ele não confere a ela senão pelo direito que lhe cabe, em virtude do nome que ela porta, quer dizer desde sua essência.

Ele mencionou primeiramente as mulheres porque elas representam o princípio passivo; do mesmo modo que a natureza primordial "precede" aqueles que são existenciados a partir dela, por meio da forma. A Natureza primordial não é verdadeiramente nada diferente do sopro do todo-misericordioso, uma vez que é nele que se desdobra as formas do mundo, do mais elevado ao mais baixo, graças à efusão da insuflação na substância primordial, mas unicamente dentro do domínio da manifestação corpórea. Sua efusão em vista da existência dos espíritos luminosos e dos "acidentes" é diferente. ${ }^{166}$

Assim, dizer que o homem decorre do sopro do todo-misericordioso, significa dizer que o homem, como existente determinado, decorre da atualização daquilo que a essência do real emana, a partir do nome presente no interior da forma adâmica - "o todo-misericordioso". Esse nome, por sua vez, consiste na atualização da ideia universal correspondente, sem o qual, o existente não poderia ser determinado.

De acordo com o modo como a existência determinada é dada, há uma hierarquia, entre os seres existentes, que obedece a ordem pela qual procedem do real. De modo que a mulher, não ocupa o mesmo posto que o homem, não pelo fato do homem proceder diretamente de Adão, pois qualquer existente determinado dele procede, mas porque o real encontra-se na mulher de modo que o homem nela reconhece parte de si mesmo porque ela também dele procede.

6. (...) O homem está "inserido" entre a essência divina da qual procede a manifestação e a mulher, cuja manifestação procede dele; ele está entre dois femininos, um feminino quanto à essência e um feminino de fato. De todo modo, "as mulheres" são um feminino de fato e a prece ritual não o é. O perfume é um masculino colocado entre os dois, assim como Adão está colocado entre a essência a partir da qual ele foi existenciado e Eva que foi existenciada a partir dele. (...). ${ }^{167}$

E, graças à insuflação na substância primordial, cada existente conserva, em relação à instância que o precede, uma atitude passiva e, em relação à instância que dele procede, uma atitude ativa. É nesse sentido que a mulher apresenta-se como passiva face ao seu esposo.

7. Quanto à sabedoria relativa ao perfume que ele mencionou após as mulheres, tratase dos cheiros da existenciação que se encontram nelas, assim como dizemos correntemente, "o melhor perfume é o abraço da amada". ${ }^{168}$

\footnotetext{
166Ibn 'Arabī, Le livre des chatons des sagesses, op. cit., pp 697 e 698.

${ }^{167}$ Ibidem, p. 700.

${ }^{168}$ Ibidem, p. 700.
} 
Depois das mulheres, os perfumes vêm a ser mais um correspondente da trindade originária que revela outro aspecto referente à dinâmica que compreende a existenciação. A partir dos nomes divinos, as mulheres guardariam a correspondência mais próxima à forma. Através do nome - o primeiro nome sendo "o todo-misericordoso" - o real, ao pronunciá-lo, coloca em fluxo, através do sopro em uma forma determinada, a sua essência que junto com o nome flui exalando o cheiro da existenciação. É possível notar como o autor não deixa de mencionar nenhum dos cinco sentidos humanos, todos eles podem ser utilizados para o reconhecimento da verdadeira realidade, para a contemplação da presença do amado, do senhor, de Deus. Pois, como bem lembra Ibn 'Arabī, Deus não pode ser contemplado na ausência de um suporte sensível, ainda que sua essência independa do que se passa em qualquer mundo. Assim, tem-se que o perfume acompanha o eclodir de toda forma, ele é a percepção sensível da essência que procede de Deus. Reconhecer esse perfume nas mulheres é reconhecer a presença dessa essência e realizar a síntese, ou seja, compreender a essência tanto da mulher, quanto do amor, quanto de si mesmo e de seu senhor.

(...) Ele foi criado servo desde sua origem. Ele jamais levantou a sua cabeça em vista do senhorio. Ele não cessou de prosternar-se, sem jamais deixar seu estado de receptividade, afim de que Deus existenciasse a partir dele o que ele existenciou. Com efeito, ele lhe conferiu uma função ativa no mundo dos sopros que são os cheiros perfumados. É por isso que o perfume lhe fora dado como digno de amor e que fora mencionado após as mulheres. (...) $)^{169}$

8. (...) Ele descreveu seus cheiros como perfumados uma vez que a palavra é um sopro e esse é a essência do odor que sai, perfumado ou mau-cheiroso segundo a forma do que foi dito. Enquanto ela seja divina pela fonte, a palavra é inteiramente boa; em contrapartida, enquanto ela é louvável ou censurável, terá um bom ou mau cheiro. $(\ldots) .^{170}$

Toda palavra é um sopro fluido do real, toda palavra é a essência na forma de um nome. Aquele que recebe o sopro deve conservar sua condição segundo sua essência, por meio da ciência divina, como o faz o profeta, a fim de que a essência não cesse de propagar-se através do nome para que seja devidamente contemplada.

10. O terceiro termo, através do qual a incomparabilidade tornou-se perfeita, é a prece ritual; ele disse: “... e o frescor do meu olho foi colocado na prece ritual” porque ela é

169 Ibidem, p. 701.

170 Ibidem, pp. 701 e 702. 
uma contemplação; e isto porque ela é um intermediário entre deus e seu servo, conforme sua palavra: Mencione- me, eu o mencionarei ${ }^{171}$.

A oração é uma obra de adoração "partilhada entre deus e seu servo em duas metades: uma metade pertence à deus e a outra ao servo", assim como foi dito numa notificação verídica enunciada diretamente por Deus o altíssimo: 'Eu partilhei a prece ritual entre eu e meu servo em duas metades: uma metade me pertence, a outra pertence ao meu servo; e ao meu servo virá o que ele pedir. (...). ${ }^{172}$

Com esse parágrafo, é importante retomar o que fora dito a respeito da sabedoria muhammadiana ser essencialmente profética, em vista da auto-orientação divina implicada na concepção de Adão, existindo com o propósito de tornar o real manifesto e, assim, poder ver a si mesmo. Pois, é nesse sentido que se deve compreender o terceiro termo, a prece, como sendo o termo ${ }^{173}$ por meio do qual a incomparabilidade da sabedoria muhammadiana torna-se perfeita, isto é, atualiza-se na existência determinada.

Esses não são quaisquer aspectos sensíveis, mas são, justamente, os aspectos que funcionam como engastes, como receptáculos por excelência para que o sopro do todomisericordioso continue fluindo desde sua essência na direção das formas determinadas e continue fluindo dos existentes. O real escolhe, assim, os receptáculos através dos quais, todo homem e toda mulher podem, de maneira perfeita, contemplar sua essência.

Aquele que contempla o real, reconhece a essência na mulher, no cheiro e na oração. Dessa forma, na oração, a adoração é partilhada entre o senhor e o seu servo. O frescor dá-se nos olhos porque atualiza a vontade do real de ver a si mesmo. Na prece, o real ele mesmo - olha e se reconhece, fala e se ouve, pede e se atende, adora e se vê adorado. Junto com seu servidor, o Senhor assume ambos os aspectos no servo, o ativo e o passivo, não estando apenas junto, mas assumindo-o completamente como a si mesmo, absorvendo-o em si mesmo, através desse ato em que servo e senhor confundem-se, tornam-se um, assim como o homem e a mulher unem-se para unirem os polos passivo e receptivo, tornando-se ambos perfeitos ao contemplarem, desse modo, o real.

11. (...) Aquele que menciona Deus permanece em sua companhia e Deus permanece na sua, pois, segundo uma tradição verídica de origem divina, o altíssimo disse: "eu permaneço na companhia daquele que me menciona". Ora, quem permanece na companhia daquele que menciona estando totalmente dotado de visão, vê seu companheiro; esse estado comporta, às vezes, contemplação e visão. Ao contrário,

\footnotetext{
${ }^{171}$ Cor., 2, 152.

${ }^{172} \mathrm{Ibn}$ 'Arabī, Le livre des chatons des sagesses, op. cit., p. 705.

${ }^{173} \mathrm{Tal}$ como a verdade da conclusão que procede da verdade das premissas.
} 
aquele que não é dotado de visão não o vê. Disso, aquele que realiza a prece conhece seu próprio grau. (...).

Aquele que não chega ao grau da visão na prece, não alcança o fim supremo e não encontra o "frescor dos olhos", pois não vê aquele com quem conversa. (...). ${ }^{174}$

Podemos pensar sobre o aspecto da visão, como sendo um aspecto que indica a perfeição daquele que realiza a prece. Parece haver uma forte aproximação entre essa visão do servo e a visão que o real deseja ter de si mesmo, a imagem de si refletida em outro. Como se essa última encontrasse, na visão que o servo tem de seu senhor por meio da prece, sua máxima realização.

12. Faz parte disso: como a realidade atual procede de um movimento inteligível que faz com que o mundo da não-manifestação passe à existência, a prece ritual reúne todas as tendências que se ramificam em três movimentos: um movimento ascendente, que corresponde ao momento em que aquele que realiza a prece se coloca de pé, um movimento horizontal, que corresponde ao momento em que ele se inclina, e um movimento descendente, que corresponde ao momento da prosternação.

A tendência fundamental do homem é ascendente; a do animal, horizontal; a do vegetal, descendente. Quanto ao mineral, ele é desprovido de tendência própria: uma pedra não pode ser colocada em movimento senão por outro que não ela. ${ }^{175}$

13. Ele disse: “... e o frescor do meu olho foi colocado na prece”, ele se exprimiu de maneira a não atribuir esse efeito a ele mesmo, pois o transbordamento que Deus destina a aquele que realiza a prece retorna unicamente ao altíssimo, não a aquele que a realizou. Se ele não tivesse mencionado essa virtude nele, Deus lhe teria ordenado de realizar a prece sem que ele se desvelasse por transbordamento a ele! Como esse transbordamento vem de sua parte como um puro dom, a contemplação é um puro dom; é por isso que ele disse: "o frescor de meu olho foi colocado na prece". ${ }^{176}$

A respeito da prece, se não fosse dessa maneira, não seria possível reconhecer a essência através de suas formas determinadas, o real, por meio delas, não se revelaria.

Trata-se unicamente da contemplação do amado pela qual o olho do amante é "refrescado", uma vez que a raiz verbal desse termo comporta as ideias de "estabilidade" e de "repouso": o olho repousa em sua vista e não vê, com ele, nada que não seja ele, naquilo que é uma coisa ou naquilo que não o é. (...) ${ }^{177}$

174 Ibidem, pp. 706 e 707.

175 Ibidem, pp. 708 e 709.

176 Ibidem, p. 709.

177 Ibidem, pp. 709 e 710. 
$\mathrm{Na}$ visão proveniente da prece, há a ideia de retorno que compreende certo descanso por encontrar aquilo que se esperava encontrar, aquilo que ardia, por um desejo ardente, na falta, repousa agora no encontro.

14. O que chamamos de prece ritual comporta uma outra divisão. Com efeito, o altíssimo ordenou-nos que realizássemos a prece, fazendo inteiramente que soubéssemos que é ele que a realiza em nós. Há, desse modo, uma prece que procede de nós e uma prece que procede dele.

Uma vez que é ele quem reza, ele o faz unicamente através de seu nome "o último", uma vez que ele vem "depois" da realidade atual do servo; trata-se, com efeito, essencialmente do Deus que o servo crê em seu coração, através de sua especulação racional ou da sua convicção dogmática, e que é a "divindade" visada nas profissões de fé. Ela se diversifica segundo a capacidade da pré-disposição própria a cada receptáculo. Interrogamos Junayd sobre o conhecimento de Deus e sobre o conhecedor; ele respondeu: “A cor da água é a cor de seu recipiente'. Essa é uma resposta perfeitamente adequada, que exprime a realidade tal como ela é. Isso é Deus uma vez que ele "reza sobre nós". ${ }^{178}$

A prece, de fato, é uma forma de contemplação excelente, sem intermediário, entre o senhor e seu servo e mesmo assim, ela comporta, como já foi dito, a dimensão ativa e passiva, dada a condição do servo e o modo como Deus dessa ação participa.

No entanto, a forma de contemplação, o que pode ser contemplado, quem contempla e os efeitos dessa contemplação, variam bastante de acordo com o entendimento e a ciência que cada servo alcança, uma vez que ele é, da essência, a parte determinada. Por isso, é sumamente importante que a ciência esteja devidamente engajada na oração, de modo que, na sua forma mais perfeita, a prece seja realizada como contemplação passiva e ativa, tanto por parte do servo, quanto por parte de seu senhor ${ }^{179}$, uma vez que o real deseja contemplar a si mesmo.

O servo, sendo receptivo ao seu senhor, oferece ativamente sua prece a ele, ao fazê-lo, compreende que sua ação é a ação de seu senhor através dele, dada sua inclinação essencial, reconhecendo sua passividade na sua atividade. Mas, quando o servo assim procede, por meio da ciência mais elevada, não se pode mais distinguir quem faz o que, o servo ou seu senhor? A união de ambos acontece, assim como a suprema visão.

\footnotetext{
178 Ibidem, pp. 710 e 711.

179 A respeito da divindade visada através das profissões de fé, Ibn'Arabī desenvolve uma apresentação importante no prefácio do Futuhat : Las iluminaciones de la Meca. Trad. e notas: Victor Pallejà de Bustinza. Madrid: Ediciones Siruela, 2005, pp. 55 à 84.
} 
Já que somos nós que rezamos, é para nós que retorna o nome "o último"; nós somos nele de um modo análogo ao que mencionamos a respeito daquele, a quem esse nome pertence: nós somos próximos dele segundo a capacidade de nosso estado, e ele nos olha unicamente na forma com a qual o abordamos. (...) $)^{180}$

(...) Aquele que se limita a esse objeto de adoração particular se mostra ignorante nisso, sem qualquer dúvida, do fato mesmo que ele se opõe aos outros em suas conviç̧ões dogmáticas a respeito de Deus; uma vez que, se ele conhecesse o significado da palavra de Junayd: "a cor da água é aquela de seu recipiente", ele deixaria a cada um sua própria crença; ele conheceria Deus em todas as formas e em todas as profissões de fé. Ele tem apenas uma opinião, não uma ciência; é por isso que ele disse: "Estou próximo da opinião que meu servo tem de mim"; eu não me manifesto a ele senão na forma de sua crença: se ele o quer, em modo absoluto; e se ele o quer, de modo condicionado. ${ }^{181}$

Uma vez que a existência compreende, em si, esse duplo aspecto, a essência e a existência determinada, o real encontra-se nela manifesto e oculto. Cada ser humano pode percebê-lo ou não, pode conhecê-lo ou ignorá-lo completamente. Sendo que, se o conhece, é porque conhece a si mesmo e, se o ignora, desconhece a si próprio.

(...) A divindade das convicções dogmáticas é prisioneira das limitações; é a divindade que contém o coração de seu servidor. A divindade absoluta, nada pode contê-la, uma vez que ela é a essência das coisas e a essência dela mesma; não podemos dizer de alguma coisa, nem que ela contem a si mesma, nem que ela não se contem. Portanto compreenda!

E Deus diz o verdadeiro, e é ele quem guia na via. ${ }^{182}$

Ao conhecer o real, o homem o faz na medida da ciência adquirida, na medida em que os atributos que lhe foram designados, assim o permitem. Se não puder conhecer nada além da existência determinada, seu conhecimento de Deus será também, por ela, condicionado.

E, se o homem que conhece a verdade, a conhece conforme a ciência dos segredos, conforme o conhecimento do que permanece oculto no interior de toda determinação, e, se esse mesmo homem, reconhece-o em sua esposa, no perfume e na visão que tem de seu senhor, na prece ritual, então ele realiza a própria natureza do real, sua própria essência, assim como sua vontade suprema. O real guia-nos na via, atraindo-nos de volta para si, por meio do reconhecimento da essência divina que existe de modo determinado como cada existente.

${ }^{180} \mathrm{Ibn}$ 'Arabī, Le livre des chatons des sagesses, op. cit., p. 711.

181 Ibidem, p. 713.

182 Ibidem, p. 713. 


\section{CONCLUSÃO}

Inicialmente indicamos, ao longo da história do pensamento arabo-islâmico, as raízes teóricas que configuraram, num contexto cultural mais amplo, o ambiente epistemológico a que pertenceu nosso autor, contemplando, com isso, as influências originárias de seu modo discursivo.

Vimos como a imagem do engaste, que confere título ao livro, permanece ativa durante todo o texto, evidenciando a dinâmica do existente primeiro em relação a toda existência determinada. Assim como a imagem dinâmica do engaste revela a particularização dos seres através dos nomes, ela também aplica-se a qualquer peça do sistema metafísico ackbariano, em qualquer momento, revelando-se, portanto, como uma chave de compreensão não só de seu pensamento, como do modelo pelo qual propõe o conhecimento da realidade. Como uma lente, sobre o que quer que o leitor aplique a imagem do engaste, poderá observar e reconhecer o modo de operar da existência e o significado de cada uma de suas múltiplas partes no contexto da unidade.

Vimos como o real, ao determinar cada existente particular, só o faz com o propósito de se tornar conhecido. Por isso a dimensão profética é a condição necessária de todo existente determinado. Conhecer a forma de cada ser é conhecer sua alma e conhecer a alma é conhecer seu nome ${ }^{183}$, sem o qual não haveria a substância que lhe é própria.

Desse modo é preciso descobrir, e esse me parece ser o principal convite de Ibn'Arabī em Kitāb fuṣuṣs al-ḥikam, o que é a substância de todo existente, não se limitando a ficar apenas com os conceitos e as definições teórico-filosóficos de cada existente, mas se deixando guiar pela forma como a existência toma curso no seu processo de manifestação através do nome, processo esse que o autor identifica como inteligível. Olhar, ou melhor, contemplar cada existente a partir dessa perspectiva é descobrir e saber apreciar, de acordo com a ciência mais elevada, as manifestações que procedem dos nomes divinos, é ser guiado pela essência dos nomes que procedem desde o nome misericordioso, é conhecer a essência através dos nomes, acessando assim a sabedoria que só pode revelar-se através deles, o que, no dizer do autor, é conhecer a si mesmo e ao seu senhor.

É como se, com o Kitāb fușūṣ al-ḥikam, Ibn'Arabī dotasse o sistema metafísico, que a princípio é totalmente teórico, de uma interioridade que pode ser experienciada por aquele que o conhece. Conferindo uma transparência ao seu sistema, no

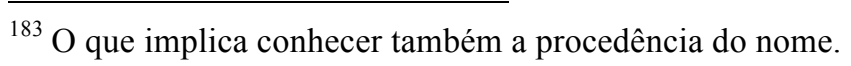


sentido de que, o tempo todo, deixa entrever o que se dá internamente quando se observa o que acontece fora dele e vice-versa. Ou seja, por fora, num sentido exotérico e filosófico, observa-se um sistema metafísico que assimila o que foi desenvolvido por Ibn Sīnā e AlFārābī, por exemplo, enquanto se pode entrever, ao mesmo tempo, o que se passa do lado de dentro, no sentido esotérico, que depende do conhecimento e da experiência que cada existente pode acessar. É como se nosso autor instalasse uma espécie de dobradiça ao sistema metafísico atribuindo, simultaneamente, a qualquer uma de suas partes duas faces, uma interna e outra externa. Ou ainda, um mesmo trânsito numa via pode adquirir um movimento ascendente na face interna e um movimento descendente na face externa. Ou seja, enquanto no sentido existencial, corpóreo, vai-se do existente primeiro aos existentes determinados, no sentido contrário, esotérico, através da ciência dos nomes, de qualquer existente determinado chega-se a sua essência, isto é, ao existente primeiro.

Assim, o sentido mais externo, exotérico, revelaria o processo de existenciação, indo do uno ao múltiplo, e o sentido interno, esotérico, ênfase dada por Ibn'Arab̄î, revelaria o processo gnoseológico, retornando do múltiplo ao uno. O sentido da manifestação só se completaria no conhecimento, sendo, a sabedoria profética, a condição de possibilidade tanto da existenciação quanto do conhecimento.

Vimos também que a ciência dos segredos é a ciência que o nome "misericordioso" reúne. Ainda assim, é preciso lembrar que nenhum nome, nenhum atributo, tem realidade em si mesmo, não há qualquer atributo, nome, profeta, existente determinado, que subsista fora da sabedoria muhammadiana. Por isso Kitāb Fușūṣ al-hikam, por ser um livro que revela essa ciência, que dela trata na medida em que se ocupa das sabedorias reveladas pelos profetas, deve ser compreendido, como propõe o autor, como um livro totalmente procedente da estação mais alta, da sabedoria muhammadiana e, portanto, necessariamente e apenas nela subsistente.

Ainda nesse sentido, enquanto o homem busca pelo conhecimento de sua essência, o real, por sua vez, na outra face do mesmo movimento, estaria atraindo para si os existentes, o que Ibn'Arabī parece identificar e descrever através da experiência de amor ou do desejo ardente. $\mathrm{O}$ amor, seria, portanto, a expressão da verdadeira natureza dos existentes como dependentes do real e apenas nele subsistentes, e quanto mais cientes dessa sabedoria, mais amor experimentam. Vale notar que a experiência de amor pertenceria e seria sofrida pelos dois polos da relação, ao mesmo tempo, ainda que não na mesma proporção, uma vez que os existentes determinados só experimentariam amor por Deus porque o amariam do 
amor do próprio Deus pelos existentes que dele procedem, sendo o amor de Deus pelas suas criaturas muito mais intenso que o amor delas por Deus.

A percepção sensível também participa plenamente da contemplação e do processo de conhecimento da essência, pois, como afirma o autor, o real não pode ser contemplado senão através de um receptáculo, isto é, toda a essência só pode ser experimentada e conhecida na medida em que assume corpo na existência determinada, assumindo com isso, qualidades sensíveis como o cheiro, por exemplo.

Se, no processo de existenciação a essência que procede do real assume a direção de se propagar procedendo sempre do mais essencial ao múltiplo e, esse processo de ida só se completa na volta, isto é, quando o processo de cognição atua no sentido inverso, o do retorno à essência, tem-se com isso que, sob essa perspectiva, qualquer ponto do sistema ackbariano adquire imediatamente uma estrutura tríptica, com dois polos e uma peça central intermediária ${ }^{184}$, através da qual pode-se sempre considerar o que ocorre nos dois sentidos: um dos polos tenderá ao outro polo, pois o fluxo precisa continuar a fluir, seja existindo seja conhecendo.

Assim, como a processão da essência no processo de existenciação é contínuo, teremos sempre uma cadeia de trípticos que nunca serão fixos, pois um elemento dessa cadeia que for um polo em uma tríade, está simultaneamente em relação tríptica com inúmeros outros elementos que, por sua vez, também assim encontram-se. De onde pode-se concluir que o que vale é a perspectiva aplicada para que seja, desse modo, reconhecido os sentidos da existência demonstrados pela metafísica apresentada em Kitāb fuṣūṣ al-ḥikam.

Inicialmente, pretendi fazer um percurso de leitura filosófica, depois de realizado o percurso, entendo ter atingido os objetivos propostos e com isso, portanto, espero que esse trabalho seja mais um instrumento de leitura a compor junto com as linhas interpretativas já consolidadas.

O livro Kitāb fușūṣ al-ḥikam, merece ser analisado em sua totalidade, considerando os vinte e cinco capítulos que ainda esperam ser contemplados sob a perspectiva apresentada a partir do presente estudo, pois certamente haveria uma série de outras questões que valeriam ser formuladas e em muito contribuiriam com o que até aqui foi possível investigar.

$\overline{{ }^{184} \mathrm{O} \text { que sempre se dá pela via do nome. }}$ 


\section{a. Bibliografia principal:}

IBN 'ARABĪ. Le livre des chatons des sagesses. tradução francesa e comentários por Charles-André Gilis. Beyrouth-Libano: Éditions Al-Bouraq, 1997. . Kitāb fuṣūṣ al-ḥikam. Beirut. 1966. . Kitāb fușūṣ al-ḥikam. Cairo: Ed. A. Afîfî, 1946. . The bezels of wisdom. Tradução e notas de R. J. W. Austin. New York: Paulist Press. 1980. . La sagesse des prophètes. Tradução e notas de T. Burckhardt. Paris: Ed. Albin Michel 1974.

\section{b. Bibliografia secundária:}

IBN 'ARABĪ. Les illuminations de la mecque. (Al-futûhât al-makkiyya). Trad. m. Chodkiewicz. Paris: Albin michel, 1988.

. Le livre du mîm, du waw et du nûn. Trad. Charles-André gilis. Beyrouth-Liban: Ed. Albouraq, 2002.

Ed. de l'éclat, 2004.

Le dévoilement des effets du voyage. Trad. Denis Gril. Paris: . L'arbre du Monde. Trad. Maurice Gloton. Paris: Ed. Les deux Océans. michel, 1986. Traité de l'amour. Trad. Maurice Gloton. Paris: Ed. Albin Tratado de la unidad. Trad.e coment. Roberto Pla Sales. Málaga: Ed. Sirio, 2002.

\section{c. Bibliografia de apoio:}

AL-FARABI. Livro dos princípios das opiniões dos habitantes d'A cidade excelente (introdução, tradução e notas de Miguel ATTIE FILHO). Tese de livre-docência, Universidade de São Paulo, 2010.

ALI SHAH, S. Princípios gerais do sufismo. São Paulo: Attar, 1987. 
AL-JABRI, M.A. Introdução à crítica da razão árabe. São Paulo: UNESP, 1997.

ANAWATI, C. G. Études de philosophie musulmane. Paris: J. Vrin, 1974.

Paris: vol.51, págs. 407 - 400, 1951.

ANAWATI, C. G. \& GARDET, L. Introduction à la théologie musulmane essai de théologie comparé. Paris: J.Vrin, 1948.

Mystique musulmane, - aspects et tendences, experiences et techniques. Paris: J. Vrin, 1961.

ARBERRY, A.J. Avicenna on Theology. London: Hyperion Press, 1951.

ARISTÓTELES. De anima. Tradução, apresentação e notas por Carlos Humberto Gomes. Lisboa: Edições 70, 2001.

. De l'âme. Trad. J. Tricot. Paris: J. Vrin, 1965.

ARISTÓTELES-PSEUDO. Teologia. Trad. e notas Luciano Rubio. Madrid: Ed. Paulinas, 1978.

ARKOUN, M. La pensée arabe. Paris: PUF, 1996.

ARNALDEZ, R. Fakr al-Dîn al-Râzî, commentateur du Coran et Philosophe. Paris: J. Vrin,2002.

- Les sciences coraniques: grammaire, droit, théologie et mystique. Paris: J. Vrin, 2005.

1983.

Trois messagers pour un seul Dieu. Paris: Albin Michel,

ATTIE $\mathrm{F}^{\circ}$, M. Falsafa: a filosofia entre os árabes: uma herança esquecida. São Paulo: Palas Athena, 2002.

Attie Editora, 2011.

Inteligência e metafísica em Ibn Sinnā (Avicena). São Paulo:

Editorial, 2007.

O Intelecto em Ibn Sina (Avicena). São Paulo: Ateliê

Eipucrs, 2000.

Os sentidos internos em Ibn Sina (Avicena). Porto Alegre:

Al-Farabi: O livro a respeito dos princípios das opiniões dos habitantes d'A cidade excelente (I - VI). In: Tiraz: Revista de estudos árabes e das culturas do oriente médio, págs. 76-105, vol. 6. São Paulo, 2009. 
AVICENNE, Le livre de science. Traduction du texte perse Danesh Nama par Mohammad Achena e Henri Massé. Paris: Les Belles Letres, 1986.

'AWÂ, 'A. L'esprit critique des frères de la pureté. Beyrouth, 1948.

BACON, R. "Perspectiva". In: Roger Bacon and the origins of perspectiva in the Middle Ages. A critical edition and english translation of Bacon's Perspectiva with introduction and notes by David C. Lindberg. Oxford: Clarendron Press, 1996.

BADAWI, A. Histoire de la philosophie en Islãm. Paris: Vrin, 1972.

Paris: J. Vrin, 1987. Paris: Maisonn

La transmition de la philosophie grecque au monde arabe. . Quelques figures et thémes de la philosophie islamique. Paris: Maisonneuve et Larose, 1979.

BARTHOLO JR.,R. Islã - O credo é a conduta. Rio de Janeiro: Imago, 1990.

BAUSANI, A. El Islam en su cultura. Mexico: Fondo de Cultura Económica, 1980.

BENEITO, P. El lenguaje de las alusiones: amor, compassin xiismo belleza en el sufismo de Ibn'Arabî. Madrid: Ed. Mandala, 2007.

- El viaje interior entre Oriente xiismo Occidente: la actualidad del pensamiento de Ibn'Arabî. Madrid: Ed. Mandala, 2007.

BRAGUE, R. Au moyen du Moyyen Age: Philosophies médiévales en chétienté, judaïsme et islam. Paris: Éditions de La Transparence, 2006.

médievales."In: Miscellanea Medievalia / Was ist philosophie in Mittelater? Berlin: Walter de Gruyter, 1998.

CAMPANINI, M. An introduction to islamic philosophy. Trad. Caroline Higgitt. Edinburgh: Ed. Edinburgh University, 2008.

CARDAILLAC. L. (org). Toledo, séculos XII-XIII. Rio de Janeiro: Jorge Zahar, 1992.

CARRA DE VAUX, B. Avicenne. Paris: Félix Alcan, 1900. Les penseurs de l'Islam. Paris: geuthner, 1984.

CHÂTEAU, J. Les grandes psychologies dans l'antiquité. Paris: J. Vrin, 1978.

CORBIN,H. Avicenne et le récit visionnaire. Paris. 1999.

Corps spirituel et terre céleste: de l'Iran mazdéen à l'Iran shî'ite. Paris: Buchet/Chastel, 1979. 
. En Islam iranien: aspects spirituels et philosophiques, Tome I et II. Paris: Gallimard, 1971.

. Histoire de la philosophie islamique. Paris: Gallimard, 1986. . L'alchimie comme art hiératique. Paris: l'Herne, 1986. . Le paradoxe du monothéisme. Paris: l'Herne, 1981.

Éditions « Présence », 1971.

. L'homme de lumière dans le soufisme iranien. Paris: Paris: Entre Lacs, 2006.

. L'imagination créatrice dans le soufisme d'Ibn'Arabî. . L'imam caché. Paris: L' Herne, 2003. . Temple et contemplation. Paris: Entre Lacs, 2006. . Temps cyclique et gnose ismaélienne, Berg International, 1982.

COSTA, J. S. Averróis, o aristotelismo radical. São Paulo: Moderna, 1994.

COVELli, A. R. M. Ibn- Rusd: a noção de ta'wil no Fasl Almaqal. Dissertação de mestrado. Universidade de São Paulo. São Paulo. 2009.

COSTA, J. S. Averróis, o aristotelismo radical. São Paulo: Moderna, 1994.

CRONE, P. e HINDS, M. God's Caliph. Religious Authority in the First Centuries of Islam, Cambridge, 1986.

D'ALVERNY, M. T. Avicenne en occident. Paris: J. Vrin, 1993.

DE LIBERA, A. A filosofia Medieval. Rio de Janeiro: Zahar, 1990. . Pensar na Idade Média. São Paulo: Ed. 34, 1999.

DEL ROIO, J. A Igreja Medieval. São Paulo: Ed. Ática, 1997.

DIEHL, C. Grandes problemas da história bizantina. São Paulo: Ed. Das américas, 1961.

DU BREUIL, P. Zoroastro. São Paulo: Ibrasa, 1988.

DUÉ, A. Atlas histórico do cristianismo. São Paulo: Vozes, 1999.

DUHEM, P. Le système du monde. Paris, 1953-1959.

ELIADE, M. Dicionário das religiões. São Paulo: Martins Fontes, 1999.

ELIAS, J. J. Islamismo. Lisboa: Edições 70, 1999. 
FAKHRY, MAJID. Histoire de la philosophie islamique. Paris: CERF, 2007.

FARAH, P. D. O Islã. São Paulo: Publifolha, 2002.

GARDET, L. Études de philosophie et mystique comparés. Paris: J. Vrin, 1972.

. La pensée religieuse d'Avicenne. Paris: Vrin, 1951.

Les grands problems de la théologie musulmane: Dieu et

la destine de l'homme. Paris: J. Vrin, 1967.

Brower, 1967.

- L'Islam, religion et communauté. Paris: Descclée de

GILLIOT, Claude. «Exégese, Langue et théologie en Islam. Lexégèse coranique de Tabari». Études Musulmanes XXXII. Paris: Vrin, 1990.

. « La théologie musulmane en Asie Centrale et au Khorasan ». Arabica: Journal of Arabic and Islamic Studies XLIX. Leiden: Brill, 2002.

GILSON, E. A filosofia na Idade Média. São Paulo: Martins Fontes, 1995.

"Les sources gréco-arabes de l'augustinisme avicennisant"

Archives d'histoire doutrinale et litéraire du Moyen Age, págs. 5-158, vol. 4, 1929-1930.

. "Avicenne et le point de départ de Duns Scot", Archives

d'Histoire Doctrinale et Littéraire de Moyen Âge, págs. 89-149, vol.2, 1927.

História da filosofia cristã. Rio de Janeiro: Vozes, 1995.

GIMARET, Daniel. Les noms divins en Islam. Paris: Édition du Cerf, 2007.

GIORDANI. História do mundo árabe medieval. Rio de Janeiro: Vozes, 1997.

GOHLMAN, A. M. The life of Ibn Sina. New York: Satate University of New York Press, 1974.

GOICHON, A.M. La philosophie d'Avicenne et son influence en Europe médievale. Paris: Librarie d'amérique et d'orient, 1940.

Désclée de Brouve, 1938.

Lexique de la langue philosophique d'Ibn Sina. Paris:

. "L' unité de la pensée avicennienne". Archives

Internationales d'Histoire des Sciences. Paris: n²0, 21, págs. 290-308, 1952.

GUERRERO, R.R. Obras filosóficas de al-Kindi. Madrid: Editorial Coloquio, 1986. Avicena. Madrid: Ed. del Orto, 1994. 
GOMES, P. A filosofia arábico-portuguesa. Lisboa: Guimarães Editores, 1991.

HERNANDEZ, MIGUEL CRUZ. Historia del pensamiento en el mundo islámico. Três Volumes. Madrid: Alianza Editorial, 2000.

$\overline{\text { Desjonquères, } 2005 .}$ . Histoire de la pensée en terre d'Islam. Paris: . La filosofia árabe. Madrid, 1990.

IBN SĪNĀ (AVICENA). Livro da alma. Tradução, introdução, notas e glossário Miguel Attie Filho. São Paulo: Globo, 2010. . La métaphysique du Shifa'. Paris: J. Vrin, 1985.

. Livre des directives et remarques. Trad. avec introduction et notes par A. M. Goichon. Paris: J. Vrin, 1951.

IBN ROCHD, (AVERRÓES). Traité décisif - L'accord de la religion et de la philosophie. Trad. Léon Gauthier. Paris: Ad. Sindbad, 1988.

. Sobre filosofia xiismo religión. Selección de textos Rafael Ramón Guerrero. Navarra: 1998.

ISKANDAR, J. I. Avicena - A origem e o retorno. Porto alegre: Edipucrs, 1999.

JAEGER, W. Aristóteles. Mexico: Fondo de Cultura Económica, 1997.

JALDUN, I. Intoducción a la historia universal. México: Fondo de Cultura Económica, 1997.

JEAN DAMACENNE, Écrits sur l'Islam (Présentation, Commentaires et Traduction par Raymond Le Coz). Paris: Éditions du Cerf, 1992.

JUBRAN, S. A. C. Hierarquia dos Povos. São Paulo: Amaral-Gurgel Editorial, 2011.

JOLIVET, J. \&RASHED, R. Études sur Avicenne. Paris: Les Belles Lettres, 1984.

1995.

. Philosophie médiévale arabe et latine. Paris: J. Vrin,

KELLENS, J. Zoroastre et l'Avesta ancien. Leuven: Peeters, 1991.

KIELCE, A. O sufismo. São Paulo: Martins Fontes, 1986.

KIKANO, A. B. Table de concordance des années hegiriennes et chrétiennes. Beyrouth, 1992.

KÜNG, H. El Islam: Historia, Presente, Futuro. Madrid: Trotta, 2006. 
KUNZMANN, P. Atlas de la philosophie. Paris: La Pochothèque, 1993.

LANDOLT, H. " Les idées platoniciennes et le monde de l'image » in DE SMET, Daniel; SEBTI, Meryaem \& DE CALLTA, Godefroid. Miroir et savoir: la transmission d'un thème platonicien, des Alexandrins à la philosophie arabo-musulmane. Louvain-la-Neuve: Leuven University Press, 2008 .

$\overline{(549 / 1155-587 / 1191)}$ et xiismo Ayn al-Quzât-i Hamadânî (492/1098525/1131)» In Recherches en Spiritualité Iranienne (Recueil d'articles). Teerã: Presses Universitaires d'Iran \& Institut Français de Recherche en Iran, 2005.

. «Suhrawardî between philosophy, sufism and ismaelism: a reappraisal» In Recherches en Spiritualité Iranienne (Recueil d'articles). Teerã: Presses Universitaires d'Iran \& Institut Français de Recherche en Iran, 2005 .

«Suhrawardî's "Tales of Initiation» In Recherches en Spiritualité Iranienne (Recueil d'articles). Teerã: Presses Universitaires d'Iran \& Institut Français de Recherche en Iran, 2005.

LANGHADE, J. Du Coran à la philosophie, la langue arabe et la formation du vocabulaire philosophique. Damas: Institut français de Damas, 1994.

LEAMAN, O. La filosofia islamica medievale. Bologna: Il Mulino, 1991. . An introduction to classical islamic philosophy. Cambridge: Cambrigde University Press, 2006.

LEWIS, B. Os árabes na História. Lisboa: Editorial Estampa, 1996.

MAHLOUBI, B. La notion d'imagination chez Avicenne. Tese de doutorado. Paris: Université de Paris I Panthéon-Sorbonne, 1991.

MANTRAN, R. Expansão muçulmana. São Paulo: Ed. Pioneira, 1977.

MASSIGNON, L. Recueil de textes inédits concernant l'histoire de la mystique en pays d'Islam. Paris: 1920. . La passion de Hallâj. Quatro volumes. Paris: Gallimard, 1975. Essai sur les origines du lexique technique de la mystique musulmane. Paris: Éditions du Cerf, 1999. Les trois prières d'Abraham. Paris: Éditions du Cerf, 1997. Parole donné. Paris: Julliard, 1962.

. Akhbar Al-Hallâj, Recueil d'oraisons et d'exhortations du martyr mystique de l'Islam. Paris: J. Vrin, 1975. 
MAZAHÉRI, A. A vida cotiniana dos muçulmanos na Idade Média. Lisboa: Ed. Livros do Brasil.

MEHREN, Traités mystiques de Aboû Alî al-Hosain b. Abdallâh b. Sinnâ ou Avicenne, texte arabe acompagné de l'explication en français par M.A.F. MEHREN. Leyden: E. J. Brill, 1888-99 [reimpresso (4 fascículo em 1 único volume) em Leiden: A. P. A., 1979], fasc. I.

MICHOT, Jean. «La réponse d'Avicenne à Bahmanyâr et al-Kirmâni. Présentation, traduction critique et lexique arabe-français de la Mubâhatha III» Mu. 110, 1997.

MONNOT, Guy. «La transmigration et l'inmortalité». Melanges de l'Institut Dominicain d'Études Orientales (MIDEO) 14 (1980).

1974. . Penseurs musulmanes et religions iraniennes. Paris: Vrin,

MORA, J. F. Diccionario de Filosofia. Buenos Aires: Sudamericana.

MOREWEDGE, P. Essays in islamic philosophiy, theology and mysticism. New York: The State University of New York at Oneonta, 1995.

MUNK, S. Mélanges de philosophie juive et arabe. Paris: J. Vrin, 1988.

NASCIMENTO, C. A. O que é filosofia medieval. São Paulo: Ed. Brasiliense, 1992.

NICOLA, A. Dicionário de Filosofia. São Paulo: Martins Fontes, 2007.

PALACIOS, M. A. El Islãm cristianizado. Madrid: Plutarco, 1931.

. Vida de santones andaluces. Madrid.

PEREIRA, R. H. S. Avicena: a viagem da alma (Uma leitura gnósticohermática de Hay Ibn Yaqzân). Dissertação de mestrado. SP. FFLCH. USP, 1998.

PLATÃO. República. Trad. e notas de Maria Helena R. Pereira. Lisboa: Fund. Calouste Gulbenkian, 1996.

ROMERO, J. L. La Edad Media. Mexico: Fondo de Cultura Económica, 1992.

ROSS, W. D. Aristóteles (Tradução de Luiz Felipe FERRREIRA). Lisboa: Dom Quixote, 1987.

RUSPOLI, S. Le livre des théophanies d'Ibn 'Arabī. Paris: CERF, 2000.

SEBTI, Meryem. avicenne. L'âme humaine. Paris: PUF, 2000.

SHAH, I. Os sufis. São Paulo: Círculo do Livro, 1987. 
SHAHRASTANI. Livre des religions et des sectes, vol. I (Traduction avec introduction et notes par Daniel GIMARET ET Guy MONNOT). Leuven: Peeters/Unesco, 1988.

Livre des religions et des sectes, vol. II (Traduction avec introduction et notes par Daniel GIMARET ET Guy MONNOT). Leuven: Peeters/Unesco, 1988.

STÉPHANE RUSPOLI. Le livre des théophanies d'Ibn Arabî: Introduction philosophique, commentaire et traduction annotée du Kitaâb al-tajalliyât. Paris: Cerf, 2000.

VALlAT, P. Farabi et l'École d'Alexandrie: Des premisses de la connaissance à la philosophie politique. Paris: J. Vrin, 2004.

VALLAUD, D. Dictionnaire historique. Paris: Librarie Arthème Fayard, 1995.

VAN RIET, G. Philosophie et religion. Louvrain: Universitaires de Louvain, 1970.

VERZA, T. M. A doutrina dos atributos divinos no Guia dos Perplexos de Maimônides. Porto Alegre: Edipucrs, 1999.

VVAA. The history of Islam. London: Cambridge University Press, 1970.

WOLFSON, H. A. "The internal senses in latin, arabic and hebrew philosophic texts", in Studies in the history of philosophy and religion. London: Harvard University Press, 1979, págs. 250-314.

YOUSIF, Ephrem-Isa. Les Philosophes et Traducteurs Syriaques: d'Athènes à Bagdad. Montréal: L'Harmattan Inc., 1997. 